\author{
UNIVERSIDADE DE SÃO PAULO \\ INSTITUTO DE PSICOLOGIA \\ DEPARTAMENTO DE PSICOLOGIA CLÍNICA
}

ALINE REDRESSA BONI RAYIS LOVO

Psicoterapia Analítica Funcional Como Tratamento de

Transtorno de Ansiedade Social

São Paulo

2019 


\section{Psicoterapia Analítica Funcional como Tratamento de Transtorno de Ansiedade Social}

Dissertação de Mestrado apresentada ao Programa de Pós-Graduação em Psicologia Clínica do Instituto de Psicologia da Universidade de São Paulo como um dos requisitos para obtenção do título de Mestre em Psicologia Clínica.

Área de concentração: Psicologia Clínica e Análise do Comportamento

Orientadora: Prof ${ }^{\mathrm{a}}$. Dra ${ }^{\mathrm{a}}$. Claudia Kami Bastos Oshiro

FAPESP/Número do processo: 2017/04888-7

São Paulo

2019 
AUTORIZO A REPRODUÇÃO E DIVULGAÇÃO TOTAL OU PARCIAL DESTE

TRABALHO, POR QUALQUER MEIO CONVENCIONAL OU ELETRÔNICO, PARA FINS DE ESTUDO E PESQUISA, DESDE QUE CITADA A FONTE.

\author{
Catalogação na publicação \\ Biblioteca Dante Moreira Leite \\ Instituto de Psicologia da Universidade de São Paulo \\ Dados fornecidos pelo (a) autor (a)
}

Lovo, Aline Redressa Boni Rayis

Psicoterapia Analítica Funcional como Tratamento para o Transtorno de Ansiedade Social/Aline Redressa Boni Rayis Lovo; orientadora Claudia Kami Bastos Oshiro -- São Paulo, 2019. 147f.

Dissertação (Mestrado - Programa de Pós-Graduação em Psicologia. Área de Concentração: Psicologia Clínica -- Instituto de Psicologia da Universidade de São Paulo.

1. Transtorno de Ansiedade Social 2. Psicoterapia Analítica Funcional 3. Processos de mudanças clínicas 4. Delineamento experimental de caso único 5. Linha de base múltipla. I Oshiro, Claudia Kami Bastos, oriente. II. Título. 
Nome: Lovo, Aline Redressa Boni Rayis

Título: Psicoterapia Analítica Funcional como Tratamento de Transtorno de Ansiedade Social

Dissertação apresentada ao Programa de PósGraduação em Psicologia Clínica do Instituto de Psicologia da Universidade de São Paulo como um dos requisitos para obtenção do título de Mestre em Psicologia Clínica.

Área de concentração: Psicologia Clínica e Análise do Comportamento

Orientadora: Prof $^{\mathrm{a}}$. Dr ${ }^{\mathrm{a}}$. Claudia Kami Bastos Oshiro

Aprovada em:

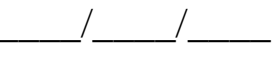

Banca Examinadora

Prof. Dr.(a)

Instituição Assinatura:

Prof. Dr.(a)

Instituição Assinatura:

Prof. Dr.(a)

Instituição Assinatura:

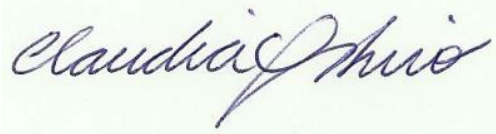


Dedico este trabalho aos meus pais,

Jaqueline e Ari, pelo apoio incondicional. 


\section{Agradecimentos}

Aos clientes que confiaram em meu trabalho e fizeram parte desta pesquisa, de maneira conjunta, meu muito obrigada.

À Claudia Oshiro, que foi muito mais que uma orientadora durante todo este processo, foi professora, amiga, mãe e, muitas vezes, minha própria psicóloga. Uma mulher admirável, forte, guerreira e extremamente competente em tudo o que se propõe a fazer. Uma mulher que levanta outras mulheres e que demonstra que a caminhada é possível, apesar de sempre desafiadora. Obrigada por ter me dado a oportunidade de fazer parte do grupo de pesquisa e permitir que eu aprendesse tanto com vocês! Obrigada pela oportunidade de ter um início acadêmico e profissional tão especial e importante ao seu lado! Obrigada por clarear os momentos dificeis deste processo e por ter me feito enxergar um potencial em mim que muitas vezes não via. E claro, obrigada também pelas inúmeras conversas, risadas, "emoções atrás de emoções" vividas no grupo! A caminhada teria sido muito mais difícil sem esses componentes!

Ao meu grupo de pesquisa, Alan Aranha, Amanda Raña, Daniel Assaz, Elisângela Ferreira, Fernanda Resende, Gabriela Lima, Gabriela dos Santos, Mariana Sartor, Renata Pinheiro e Joana Vartanian, por terem me acolhido desde o início e dado todo o suporte possível durante minha pesquisa. Em especial à Elisângela, à Renata e à Mariana, que toparam o dificil e grande trabalho de serem minhas aferidoras de concordância, e à Fernanda Resende, que atenciosamente me ajudou a entender o programa de estatística! Obrigada ao Daniel e à Amanda por muitos almoços e discussões de casos, regados à muita risada! Obrigada a todos pelos happy hours necessários e merecidos e por terem dividido comigo, não só a vida profissional, mas a vida pessoal de vocês! 
Com muito carinho, um obrigada especial à Gabriela Lima, que mais do que companheira de trabalho, tornou-se uma companheira de vida! Com sua generosidade, me acolheu como uma irmã mais velha e permitiu que eu aprendesse tanto! Ouviu meus medos, desabafos, desesperos, choros, sempre com um abraço, uma mão estendida e uma comida gostosa para ajudar! Obrigada por tornar essa minha jornada mais fácil e prazerosa! Obrigada por partilhar seus aprendizados e por ser tão generosa! Obrigada por estar sempre ao meu lado!

À Renata Bonatto, ao Gustavo Crivello Cesar e ao Daniel Amorim, pelo trabalho cuidadoso, paciente e difícil das transcrições!

À Ana Cláudia, minha psicóloga, que me acompanha e me fortalece! Obrigada por dividir tanto aprendizado comigo e ser uma fonte de inspiração pessoal e profissional!

Às minhas grandes e melhores amigas, que perto ou longe, me deram suporte, força e seguiram me empoderando antes, durante e após essa jornada: Larissa Stella, Caroline Ferreira, Carolina Souza, Isabela Moraes, Gabriela Milaré, Gabriela Berro, Helena Ometto e Fernada Zerbini! Um especial obrigada à Gabriela Milaré, que foi fonte de muito apoio e abraço nesta etapa tão difícil que é a pós-graduação!

Aos meus pais, Jaqueline e Ari, pelo amor e apoio! Por fornecerem as ferramentas e oportunidades necessárias para que eu tivesse acesso à uma boa educação e chegasse até aqui. Obrigada por sempre apoiarem qualquer decisão minha e acreditarem no meu potencial! Obrigada por sempre me ouvirem, me acolherem e aprenderem comigo. Obrigada por vibrarem junto e estarem presentes ao final dessa jornada e além! E obrigada por compreenderem o quão trabalhosa e difícil foi esta jornada, especialmente por eu não conseguir estar muito presente em vários momentos! 
Aos meus irmãos, Arianne e Paulo, que perto ou longe, seguem sendo os melhores companheiros de vida que eu poderia ter. Obrigada Arianne pelo apoio presente, por me fortalecer e me erguer nos momentos mais dificeis! Obrigada Paulo pelo apoio, carinho e proteção, mesmo que de longe, tentando sempre me ajudar e facilitar os meus caminhos!

Um obrigada à toda minha família, que sempre seguiu me apoiando e vibrando com minhas vitórias!

Às professoras Alessandra Villas-Bôas, Liane Dahás e Sônia Meyer, pela leitura cuidadosa, sugestões e futuros apontamentos acerca deste trabalho!

À Fundação de Amparo À Pesquisa do Estado de São Paulo (FAPESP), pela concessão da bolsa de estudos para que minha pesquisa pudesse ser realizada. 
"Nunca cultivar a dor, mas lembrá-la com respeito, por ter sido indutora de uma melhoria, por melhorar quem se é. Se assim for, não é necessário voltar atrás. A aprendizagem estará feita e o caminho livre para que a dor não se repita".

(Valter Hugo Mãe) 


\section{RESUMO}

Lovo, A.R.B.R. (2019). Psicoterapia Analítica Funcional como tratamento de Transtorno de Ansiedade Social. Dissertação de mestrado, Instituto de Psicologia, Universidade de São Paulo, São Paulo.

Os Transtornos de Ansiedade são os diagnósticos clínicos que mais frequentemente aparecem em nossa sociedade. Dentre eles, o Transtorno de Ansiedade Social (TAS) é o mais comum e foi o objeto de estudo deste trabalho. O TAS acomete indivíduos desde a sua infância e compromete uma série de atividades sociais, acadêmicas e profissionais, dificultando o estabelecimento de relações interpessoais. O tratamento mais comumente utilizado é a Terapia Cognitiva Comportamental (TCC) aliada ao uso de fármacos, com técnicas de exposição enquanto estratégia principal e que, de acordo com estudos, revelam um índice de evasão da terapia, bem como dificuldade de implementação pelo terapeuta e aumento dos sintomas de ansiedade, devido ao caráter aversivo que a exposição pode ocasionar. Estudos em Psicoterapia Analítica Funcional (FAP) apontaram resultados positivos da FAP para alguns transtornos de ansiedade e levantaram a hipótese de que essa intervenção seria um bom manejo para indivíduos com TAS, uma vez que não foram encontradas pesquisas que avaliassem a FAP enquanto tratamento para a ansiedade social até a finalização deste trabalho. Considerando que indivíduos com TAS tendem a apresentar comportamentos de esquiva de situações que possam ocasionar julgamentos e avaliações negativas e, portanto, dificultar o estabelecimento de vínculos, e que a FAP tem como princípio proporcionar mudanças através da relação terapêutica, o objetivo do presente estudo foi avaliar a eficácia da FAP enquanto tratamento para indivíduos com TAS e analisar os processos de mudança clínica envolvidos na utilização da FAP. A metodologia foi o delineamento experimental de caso único de linha de base múltipla. Os participantes foram uma terapeuta/pesquisadora, três clientes adultos e três aferidores de concordância. A intervenção ocorreu com a introdução da variável independente (FAP) em momentos distintos para cada participante, de acordo com as fases do experimento: linha de base (Fase A) e introdução da FAP (Fase B). Uma sessão de seguimento foi realizada um mês após o término da psicoterapia para cada participante. Foram transcritas e categorizadas cinco sessões de cada fase para cada participante, com o uso do Sistema de Categorização da Psicoterapia Analítica Funcional (FAPRS), buscando encontrar os processos envolvidos nas mudanças clínicas, com ênfase na relação terapêutica. As melhoras dos clientes foram avaliadas e analisadas por meio dos seguintes instrumentos: Outcome Questionnaire (OQ-45), Beck Depression Inventory (BDI), Liebowitz Social Anxiety Scale (LSAS) e Social Phobia Inventory (SPIN). Os resultados apontaram que após a introdução da FAP os comportamentos clinicamente relevantes do tipo problema (CRB1) diminuíram consideravelmente e os comportamentos clinicamente relevantes de melhora (CRB2) aumentaram drasticamente. Os outros instrumentos não apresentaram resultados significativos em relação ao uso da FAP. Assim, este estudo pontua a eficácia da FAP para o tratamento de indivíduos com TAS, bem como do delineamento de linha de base múltipla em pesquisas de prática clínica.

Palavras-chave: Transtorno de Ansiedade Social, Psicoterapia Analítica Funcional, processos de mudanças clínicas, delineamento experimental de caso único, linha de base múltipla. 


\begin{abstract}
Lovo, A.R.B.R. (2019). Functional Analytical Psychotherapy as a treatment of Social Anxiety Disorder. Master's Thesis, Institute of Psychology, Universidade de São Paulo, São Paulo.

Anxiety Disorders are the clinical diagnoses that most appear in our society. Among them, Social Anxiety Disorder (SAD) is the most common and it was the object of study of this research. SAD affects individuals from their infancy and compromises a series of social, academic and professional activities, making it difficult to establish interpersonal relationships. The most commonly used treatment is Cognitive Behavioral Therapy (CBT), allied to the use of drugs, with exposure strategies as the main strategy and which, according to studies, reveal an evasion rate of the therapy, as well as difficulty of implementation by the therapist and increased anxiety symptoms due to the aversive character that the exposure may cause. Studies in Functional Analytical Psychotherapy (FAP) pointed out positive results from FAP for some anxiety disorders and hypothesized that this intervention would be a good management for individuals with SAD, since no research was found to evaluate FAP as a treatment for social anxiety until the end of this work. Considering that individuals with SAD tend to present behaviors that evade situations that may lead to negative judgments and assessments, and thus make it difficult to establish links, and that the FAP has as principle to provide changes through the therapeutic relationship, the objective of the present study was to evaluate the efficacy of FAP as a treatment for individuals with SAD and to analyze the clinical change processes involved in the use of FAP. The methodology was the experimental design of a single multiple baseline case. Participants included a therapist / researcher, three adult clients, and three concordance checkers. The intervention occurred with the introduction of the independent variable (FAP) at different times for each participant, according to the phases of the experiment: baseline (Phase A) and introduction of FAP (Phase B). A follow-up session was held one month after the end of the psychotherapy for each participant. Five sessions of each phase were transcribed and categorized for each participant, using the Categorization System of Functional Analytical Psychotherapy (FAPRS), seeking to find the processes involved in clinical changes, with emphasis on the therapeutic relationship. Clients improvements were evaluated and analyzed using the following instruments: Outcome Questionnaire (OQ-45), Beck Depression Inventory (BDI), Liebowitz Social Anxiety Scale (LSAS) and Social Phobia Inventory (SPIN). The results showed that after the introduction of FAP, clinically relevant behaviors of the problem type (CRB1) decreased considerably and clinically relevant behaviors of improvement (CRB2) increased dramatically. The other instruments did not present significant results regarding the use of FAP. Thus, this study scores the efficacy of FAP for the treatment of individuals with SAD as well as multiple baseline delineation in clinical practice research.
\end{abstract}

Keywords: Social Anxiety Disorder, Functional Analytical Psychotherapy, clinical change processes, single-case experimental design, multiple baseline. 


\section{LISTA DE FIGURAS}

Figura 1. Transtornos de ansiedade e os eventos aversivos correspondentes

Figura 2. Critérios e sintomas do DSM para o TAS

Figura 3. Delineamento experimental de caso único de linha de base múltipla entre participantes. Legenda: Fase $\mathrm{A}=$ linha de base; Fase $\mathrm{B}=$ introdução da variável independente $(\mathrm{FAP})$ e, FUP = sessão de seguimento (follow-up)

Figura 4. Porcentagem acima do nível clínico para o instrumento OQ-45, por categoria e por participante, durante a linha de base múltipla (A), a fase experimental (B) e fase de seguimento (FUP), respectivamente: (1) Rodolfo, (2) Walter e (3) Murilo. A linha tracejada indica a mudança de fase

Figura 5. Pontuação bruta para o instrumento BDI, por participante, durante a linha de base múltipla para (1) Rodolfo, (2) Walter e (3) Murilo. Legenda: A = Linha de base; B $=$ FAP e FUP $=$ seguimento. A linha tracejada preta indica a mudança de fase 92

Figura 6. Pontuação bruta para o instrumento LSAS, por participante, (1) Rodolfo, (2) Walter e (3) Murilo, no decorrer das sessões. Legenda: A = linha de base; B = FAP e FUP $=$ seguimento. $\mathrm{A}$ linha tracejada preta indica mudança de fase

Figura 7. Pontuação bruta para o instrumento SPIN para os participantes (1) Rodolfo, (2) Walter e (3) Murilo, no decorrer das sessões. Legenda: A = linha de base; B = FAP e FUP $=$ seguimento. A linha tracejada preta indica mudança de fase

Figura 8. Frequência dos comportamentos do cliente: CRB1 e CRB2, ao longo do delineamento experimental, por participante: (1) Rodolfo, (2) Walter e (3) Murilo. Legenda: $\mathrm{A}=$ linha de base; $\mathrm{B}=\mathrm{FAP}$ e FUP = seguimento. A linha preta tracejada indica mudança de fase

Figura 9. Frequência de comportamentos do terapeuta, de acordo com a Regra 1, Regra 2, Regra 3, Regra 4 e Regra 5, ao longo das fases do experimento, por participante: (1) Rodolfo, (2) Walter e (3) Murilo. Legenda: A= linha de base; B = FAP e FUP = seguimento. A linha preta tracejada indica mudança de fase

Figura 10. Frequência de comportamentos do terapeuta, de acordo com a Regra 2, Regra 3-1 e 3-2 relacionadas aos CRB1 e CRB2 ao longo das fases do experimento, por participante: (1) Rodolfo, (2) Walter e (3) Murilo. Legenda: A= linha de base; B = FAP e FUP = seguimento. A linha preta tracejada indica mudança de fase 121 


\section{LISTA DE TABELAS}

Tabela 1. Índice de concordância percentual obtido entre a pesquisadora-terapeuta e os aferidores de concordância em cada sessão categorizada pelo FAPRS

Tabela 2. Índice de concordância percentual obtido entre a pesquisadora-terapeuta e os aferidores de concordância em cada sessão categorizada pelo FAPRS

Tabela 3. Índice do coeficiente kappa de Cohen obtido entre a pesquisadora-terapeuta e os aferidores de concordância em cada sessão categorizadas pelo FAPRS

Tabela 4. Comportamentos clinicamente relevantes da classe A de dentro da sessão: do tipo problema (CRB1) e do tipo melhora (CRB2), e comportamentos problema extrassessão $(\mathrm{O} 1)$ e de melhora extrassessão $(\mathrm{O} 2)$

Tabela 5. Comportamentos clinicamente relevantes da classe B de dentro da sessão: do tipo problema (CRB1) e do tipo melhora (CRB2), e comportamentos problema extrassessão $(\mathrm{O} 1)$ e de melhora extrassessão $(\mathrm{O} 2)$

Tabela 6. Comportamentos clinicamente relevantes da classe A de dentro da sessão: do tipo problema (CRB1) e do tipo melhora (CRB2), e comportamentos problema extrassessão $(\mathrm{O} 1)$ e de melhora extrassessão $(\mathrm{O} 2)$

Tabela 7. Comportamentos clinicamente relevantes da classe B de dentro da sessão: do tipo problema (CRB1) e do tipo melhora (CRB2), e comportamentos problema extrassessão $(\mathrm{O} 1)$ e de melhora extrassessão $(\mathrm{O} 2)$

Tabela 8. Comportamentos clinicamente relevantes de dentro da sessão: do tipo problema (CRB1) e do tipo melhora (CRB2), e comportamentos problema extrassessão (O1) e de melhora extrassessão $(\mathrm{O} 2)$ 
ANEXOS

ANEXO 1 -

ANEXO 2 --

ANEXO 3 -

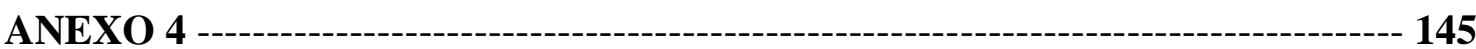

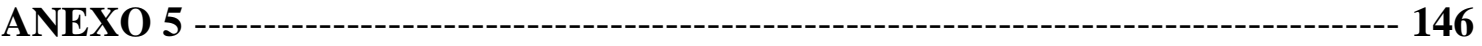




\section{SUMÁRIO}

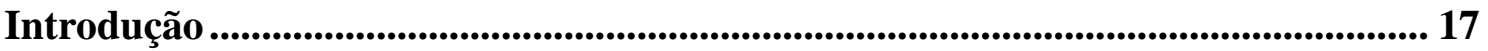

Ansiedade ................................................................................................................... 17

Transtornos de Ansiedade ................................................................................................. 23

Ansiedade Social ................................................................................................................. 25

Tratamentos para o Transtorno de Ansiedade Social ................................................... 30

Terapias de Terceira Onda: A Psicoterapia Analítica Funcional (FAP) ................... 34

FAP como tratamento para transtornos de ansiedade ............................................ 36

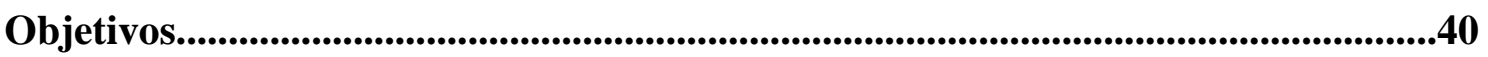

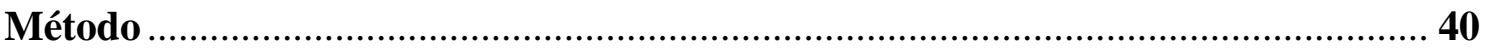

Participantes ...................................................................................................................... 40

Ambientes e Materiais ............................................................................................................... 41

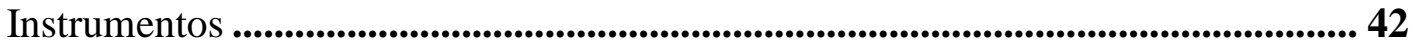

Mini International Neuropsychiatric Interview (M.I.N.I) ............................. 42

Sistema de Categorização da Psicoterapia Analítica Funcional (FAPRS)......... 42

Outcome Questionnaire (OQ-45) ............................................................... 43

Escala de Depressão de Beck (BDI) ................................................................. 43

Liebowitz Social Anxiety Scale (LSAS) ........................................................ 44

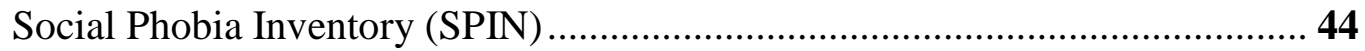

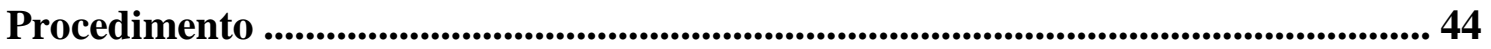

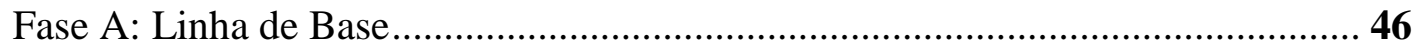

Fase B: Introdução da variável independente FAP ............................................... 48

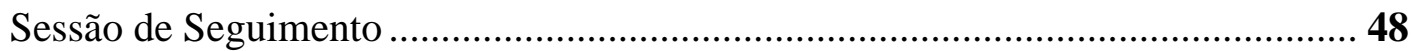

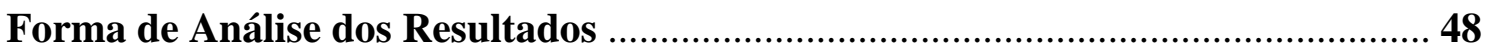

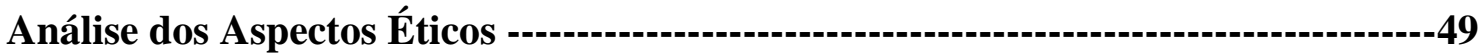

Aferição de Concordância............................................................................................................ 50

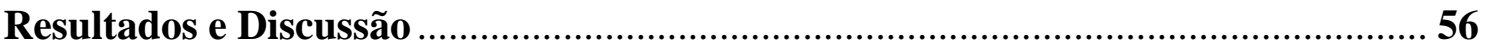

(1) Conceituação de Casos ................................................................................ 57

(2) Dados do Instrumento de Triagem M.I.N.I.............................................................. 83

(3) Dados das Medidas Externas ................................................................................... 83

(a) OQ-45 ................................................................................................................................. 83

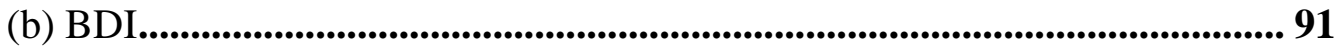

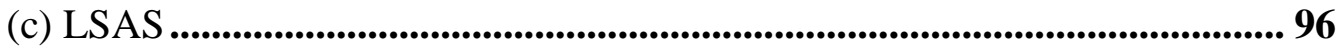

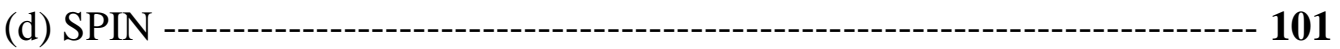


(4) Escala de Avaliação da Psicoterapia Analítica Funcional

Conclusão

Referências

$-129$ 


\section{Ansiedade}

A palavra ansiedade tem sido amplamente utilizada para caracterizar diferentes estados físicos e/ou psicológicos em contextos sociais bastantes variados (Coêlho, 2006). O senso comum tem como prática utilizar o termo como metáforas para várias situações, o que pode ilustrar a imprecisão da definição de ansiedade e dificultar a construção de explicações consistentes (Friman, Hayes \& Wilson, 1998). Além deste termo ser utilizado para designar diferentes reações corporais e psicológicas, ele refere-se a um fenômeno inerente ao ser humano, dado que a ansiedade faz parte de respostas naturais do organismo a situações que sinalizem perigo e/ou prazer, ou seja, está associado ao mesmo tempo à conceitos bons e ruins. Com isso, apesar de, na maioria das vezes, a ansiedade estar associada a sintomas desagradáveis e ser caracterizada como algo ruim, é importante considerar que também está associada a eventos agradáveis, principalmente em relação àqueles que envolvem situações de espera por algo que se deseja (Zamignani \& Banaco, 2005). O uso amplo deste termo, portanto, fez com que vários autores o utilizasse sob a ótica de sua linha teórica, e o conceituasse de maneiras diferentes (Coêlho, 2006). Recentemente, a REDETAC vem levantando discussões acerca do tema da ansiedade, com o objetivo de produzir evidências a respeito das terapias analítico-comportamentais e, futuramente, poderá também colaborar para esclarecer melhor tal conceito.

Para dar início a uma tentativa de caracterização do fenômeno, podemos partir da diferenciação entre uma emoção bastante relacionada e, muitas vezes, confundida com a ansiedade, o medo. Gentil (1997) relata que alguns autores definem a ansiedade como um estado emocional desagradável, voltado para o futuro, que guarda relação com o medo, o qual, frequentemente, é confundido com a ansiedade. De acordo com O Manual Diagnóstico e Estatístico de Transtornos Mentais (5 $5^{\circ}$ edition - American Psychiatric Association [APA], 2013), os transtornos de ansiedade compartilham várias 
características de medo e ansiedade excessivos e perturbações comportamentais que se relacionam e, uma vez que estes dois estados partilham de características que se sobrepõem, é fundamental a diferenciação entre eles. Quando uma resposta emocional é emitida diante de uma ameaça real e iminente, caracterizamos a resposta como medo. A ansiedade, por outro lado, é caracterizada por respostas emocionais emitidas diante da antecipação de uma ameaça futura. Em termos fisiológicos, por exemplo, o medo é mais frequentemente associado a períodos de excitabilidade autonômica aumentada, reações essenciais para situações de luta ou fuga imediatas. A ansiedade, por sua vez, é bastante associada a situações de preparação para perigos futuros e comportamentos de cautela ou esquiva, reagindo fisiologicamente com contração e tensão muscular e vigilância. Neste caso, é importante salientar que o que diferencia os transtornos de ansiedade do medo ou da ansiedade adaptativos é que os primeiros ocorrem em excesso ou persistem além de períodos apropriados ao nível de desenvolvimento (APA, 2013).

Outra discussão importante é a diferenciação entre aquilo que denominamos como ansiedade "normal", daquela denominada de "anormal" ou "patológica". De acordo com Barbosa (2004), a ansiedade considerada "normal", nomeada por ele de "boa ansiedade", é aquela proporcional às situações de dificuldades vivenciadas por um indivíduo e capaz de promover um enfrentamento saudável dessas situações. Por outro lado, a ansiedade chamada por ele de "má ansiedade", considerada "anormal", seria aquela desproporcional às dificuldades e capaz de impossibilitar o indivíduo de agir de maneira produtiva diante de situações de problemas. Para o autor, o limite entre a ansiedade normal e a anormal está na frequência e intensidade de respostas ansiosas emitidas pelo sujeito diante de um evento futuro. Castillo, Recondo, Asbahr \& Manfro (2000), afirmam que a maneira mais prática de diferenciar a ansiedade normal da ansiedade patológica é avaliar algumas características da resposta emitida, tais como se a reação ansiosa é de curta ou longa 
duração, autolimitada ou disfuncional e se está relacionada ao estímulo do momento ou não.

Do ponto de vista conceitual, são encontradas algumas definições importantes acerca do tema, a depender da área de pesquisa. No presente estudo, o conceito será discutido no enfoque analítico-comportamental sobre os transtornos de ansiedade. Coêlho (2006) examinou alguns trabalhos que envolviam diversos usos do conceito de ansiedade para a análise do comportamento. De acordo com a visão comportamental, o fenômeno da ansiedade tem sido estudado em pelo menos duas direções, quais sejam a) a primeira com uma ênfase em relações operantes não verbais e, a segunda, b) em relações verbais e em possíveis relações indiretas entre estímulos (Coêlho, 2006). Ainda assim, os diferentes usos do conceito de ansiedade ilustrados nos trabalhados examinados envolvem pontos comuns, como a referência a componentes fisiológicos, condicionamento operante e respondente, direto e indireto, não verbal e verbal, além de relações com operações estabelecedoras e a terapia verbal (Coêlho, 2006).

Algumas explicações analítico-comportamentais compõem o entendimento da ansiedade. Essas explicações representam diferentes níveis de análise e de complexidade desse fenômeno: condicionamento reflexo, condicionamento operante, relações de reforçamento positivo e negativo, paradigma de supressão condicionada, responder relacional, equivalência de estímulos e transferência de função, teoria dos quadros relacionais (Linares, Perez \& Nico, 2013). De acordo com Zamignani e Banaco (2005), existe um rótulo sob o conceito de ansiedade e, para este ser definido, é necessário analisar qual a natureza dos eventos envolvidos. Na realidade, o fenômeno ansiedade tem sido definido muito mais como um conceito do que como um fenômeno empírico (Friman, Hayes \& Wilson, 1998; Zamignani \& Banaco, 2005). Para Kanfer e Phillips (1970), por exemplo, a ansiedade é um constructo frequentemente definido a partir de três diferentes 
perspectivas de observação: a) com base na descrição verbal do estado interno da pessoa; b) pela avaliação de padrões fisiológicos e comportamentais e, c) por meio de operações experimentais.

Alguns dos primeiros autores a encabeçarem o estudo de uma definição para a ansiedade foram Estes e Skinner (1941). Para eles, a ansiedade pode ser definida enquanto um estado emocional semelhante ao medo, no qual o estímulo perturbador, aversivo é antecipado no futuro, e não precede ou acompanha o mesmo. Em outras palavras, a ansiedade poderia ser definida a partir da variável de antecipação do estímulo aversivo condicionado. Além disso, para aprofundar ainda mais esta análise, os autores propõem que se deve acrescentar que a ansiedade também é constituída por respostas operantes e, no caso, de fuga e esquiva de estímulos aversivos, condicionados ou incondicionados (Estes \& Skinner, 1941). Queiroz e Guilhardi (2001) propõem que a análise experimental do comportamento descreve o paradigma da ansiedade na medida em que um estímulo sinaliza a apresentação de um estímulo aversivo e não há a possibilidade de fuga-esquiva. Assim, na presença do estímulo pré-aversivo, são produzidos estados corporais e supressão de comportamentos. Este estado corporal, sentido sob tais condições, pode ser chamado de ansiedade. Para Sidman (1989/2003), os estímulos aversivos incondicionados ou condicionados também evocam, comumente, respostas de fuga e esquiva, geralmente denominadas como "ansiedade". Zamignani e Banaco (2005) também afirmam a importância do estímulo aversivo na definição de ansiedade. Para os autores, a antecipação do estímulo aversivo é uma característica essencial para o fenômeno, sendo necessário analisar os conceitos de estímulo aversivo condicionado (ou pré-aversivo). Para Castillo (2000), a ansiedade é caracterizada como um sentimento de medo vago e desagradável, caracterizado por um desconforto ou tensão derivado de uma antecipação de perigo, de algo desconhecido ou estranho. Porém, outros autores afirmam 
que a ansiedade é um fenômeno adaptativo essencial ao homem para o enfrentamento de situações cotidianas (Grazziano \& Bianchi, 2004), exercendo uma função adaptativa ligada a mecanismos de sobrevivência, defesa territorial, seleção de companheiro, dentre outros (Assumpção, 2009).

Sidman (1989/2009) estudou os processos básicos relevantes envolvidos na ansiedade, como o controle aversivo e as respostas decorrentes de fuga e esquiva. Para este autor, os indivíduos sob controle de contingências aversivas tendem a emitir comportamentos de esquiva, mais até do que em comportamentos de fuga, uma vez que seria mais vantajoso adiar ou prevenir a ocorrência de estímulos aversivos do que entrar em contato com eles. Skinner (1957) compartilha desta proposição ao afirmar que grande parte do que fazemos não visa obter reforços positivos, mas sim evitar consequências aversivas.

Cada perspectiva tomada produz conhecimentos e técnicas diferentes. Zamignani e Banaco (2005) destacaram vários elementos comuns entre as definições de ansiedade encontradas: estado que envolve excitação biológica ou manifestações autonômicas e musculares (taquicardia, respostas galvânicas na pele, hiperventilação, sensações de afogamento ou sufocamento, sudoreses, dores e tremores), redução na eficiência comportamental (decréscimo em habilidades sociais, dificuldade de concentração), resposta de esquiva e/ou fuga (o que sugere expectativa ou um controle por eventos futuros) e relatos verbais de estados internos desagradáveis (angústia, apreensão, medo, insegurança, mal-estar indefinido etc) (Gentil, 1998; Kanfer \& Phillips, 1970).

De acordo com todas essas perspectivas, o conceito de ansiedade necessariamente deve envolver o anúncio de que algum evento aversivo vai ocorrer. Para Zamignani e Banaco (2005), sua definição implica um futuro carregado de aversividade. Além disso, invariavelmente, grande parte das definições dos fenômenos tidos como instâncias de 
ansiedade fazem referência ao que se passa com a fisiologia do organismo. Porém, o foco apenas nas condições fisiológicas pode fazer com que as contingências que de fato produzem a ansiedade fiquem em segundo plano nas interpretações oferecidas (Barlow, Rapee \& Brown, 1992; Zettle, 2003). Zamignani e Vermes (2003) afirmam que, apesar de existir uma grande quantidade de trabalhos que busquem explicar os diferentes tipos de relações que podem compor o que eles chamam de "instância de ansiedade", trata-se de esforços que não integram as diversas propostas que veiculam. Com isso, continuamos sem uma sistematização dos fenômenos e de suas variáveis sob as quais os analistas do comportamento falam em ansiedade (Zamignani \& Vermes, 2003).

Em termos clínicos, a ansiedade passa a adquirir status de queixa clínica quando está relacionada a eventos aversivos em suas múltiplas possibilidades de interação (Zamignani \& Banaco, 2005). Quando analisada como queixa, a ansiedade tem sido definida como um estado emocional desagradável acompanhado de desconforto fisiológico (sensações físicas como frio na barriga, coração apertado, nó na garganta, mãos suadas, efeito paralisante), relacionada a eventos futuros e, algumas vezes, desproporcional a uma ameaça real (Zamignani \& Banaco, 2005). Portanto, para ser definida enquanto fenômeno clínico, a ansiedade deve apresentar as seguintes características: a) implicar em um comprometimento ocupacional do indivíduo, impedindo o andamento de suas atividades profissionais, sociais e acadêmicas; b) envolver um grau de sofrimento considerado pelo indivíduo como significativo; c) e as respostas de evitação e eliminação ocuparem um tempo considerável do dia. Uma vez atingidos todos esses aspectos, a literatura médica classifica esses casos como transtornos de ansiedade (Zamignani \& Banaco, 2005). Neste sentido, Gentil (1997) afirma que níveis altos de ansiedade (variando de indivíduo para indivíduo a depender de sua história de vida) podem levar a psicopatologias, a partir do momento em que há uma desproporção 
entre o evento temido e a ameaça causada pelo evento. Quando isso ocorre, pode-se observar grande sofrimento por parte do indivíduo e prejuízo em diferentes áreas de sua vida (Zamignani \& Banaco, 2005; Gentil, 1997; Hetem, 2004). A seção seguinte trará informações sobre os transtornos de ansiedade existentes, como são classificados, suas prevalências e padrões funcionais comuns entre si.

\section{Transtornos de Ansiedade}

De acordo com Zamignani e Banaco (2005), no nosso dia-a-dia, uma vasta gama de estados ansiosos é caracterizada pelas pessoas como algum transtorno de ansiedade. Porém, para a literatura médica e psicológica, a ansiedade só passa a adquirir status de queixa clínica e caracterizada enquanto um transtorno de ansiedade quando estes estados ansiosos estão relacionados a eventos aversivos que acometem grande parte do dia da pessoa, ocasionando sofrimento considerado expressivo pelo indivíduo, através do comprometimento comportamental em atividades sociais, acadêmicas e profissionais.

Os transtornos de ansiedade são os mais prevalentes entre os transtornos psiquiátricos que atingem a população geral, com prevalências de 12,5\% ao longo da vida e 7,6\% no ano, tanto em crianças, com uma prevalência de $9 \%$ durante o período de vida, quanto em adultos, com uma prevalência estimada de 15\% (Castillo, Recondo, Asbahr \& Manfro, 2000). No caso do Brasil, pesquisas revelam taxas altas dos transtornos em amostras ambulatoriais, atingindo um valor de até $75 \%$ em tabagistas que buscam por serviço de psiquiatria (Munaretti \& Terra, 2007). Em relação ao gênero, muitas pesquisas revelam que as mulheres tendem a apresentar maior risco de desenvolver transtornos ansiosos ao longo da vida do que os homens (proporção de aproximadamente 2:1) (Andrade, Viana \& Silveira, 2006), tendo os transtornos sua origem no início da vida adulta (Kinrys \& Wygant, 2005). Ainda, muitos transtornos de ansiedade se desenvolvem 
na infância e tendem a persistir se não forem tratados. A importância em melhor compreender o fenômeno reside no alto índice de crescimento dos transtornos ansiosos nas últimas décadas (Fermoseli, Guimarães, Neto, Vilar, Almeida \& Albuquerque, 2015). Na população adulta em geral, segundo Vorkapic e Rangé (2011), os transtornos de ansiedade têm crescido exponencialmente.

Em termos comportamentais, os transtornos de ansiedade têm um padrão funcional comum entre si, caracterizado pela esquiva fóbica, a qual se define pela tentativa de o indivíduo eliminar, amenizar ou adiar um evento ameaçador. Apesar desse padrão comportamental comum, os transtornos de ansiedade se diferenciam pelo tipo de evento aversivo para o indivíduo, informações apresentadas na Figura 1 abaixo:

Figura 1. Transtornos de ansiedade e os eventos aversivos correspondentes.

\begin{tabular}{|l|l|l|}
\hline Diagnóstico & Ss aversivos & Resposta de Fuga-Esquiva \\
\hline Fobias simples & Específicos & Evitação / eliminação \\
\hline Fobia social & Crítica ou avaliação de terceiros & $\begin{array}{l}\text { Evitação/eliminação, } \\
\text { Verificação }\end{array}$ \\
\hline Pânico & - Estimulação privada de medo ou \\
desconforto físico & $\begin{array}{l}\text { Evitação/eliminação, } \\
\text { Verificação }\end{array}$ \\
\hline Agorafobia & $\begin{array}{l}\text { Ambientes sem possibilidade de } \\
\text { proteção ou escape }\end{array}$ & Evitação/ eliminação \\
\hline $\begin{array}{l}\text { Stress Pós- } \\
\text { Traumático }\end{array}$ & Diversos (relacionados ao trauma) & $\begin{array}{l}\text { Verificação, } \\
\text { Evitação/eliminação, etc. }\end{array}$ \\
\hline $\begin{array}{l}\text { Ansiedade } \\
\text { Generalizada e } \\
\text { Aguda }\end{array}$ & Generalizado & $\begin{array}{l}\text { Verificação, } \\
\text { Evitação/eliminação, etc. }\end{array}$ \\
\hline TOC & $\begin{array}{l}\text { Estímulos específicos e obsessões } \\
\text { idéias, pensamentos, impulsos e } \\
\text { imagens intrusivos) }\end{array}$ & $\begin{array}{l}\text { Respostas repetitivas e/ou } \\
\text { estereotipadas/ } \\
\text { evitação/eliminação }\end{array}$ \\
\hline
\end{tabular}

Fonte: Zamignani, D.R. \& Banaco, R.A. (2005). Um panorama AnalíticoComportamental sobre os Transtornos de ansiedade. Revista Brasileira de Terapia Comportamental e Cognitiva, vol VII, no.1, 077-092 
De acordo com a Figura 1, cada diagnóstico de transtorno de ansiedade evidência possíveis estímulos aversivos, promovendo padrões de respostas parecidos, quais sejam, respostas de fuga-esquiva. No caso da ansiedade social, enfoque deste trabalho, os estímulos aversivos baseiam-se em críticas ou avaliação de terceiros.

Considerando as respostas de fuga-esquiva como características dos transtornos de ansiedade, é importante compreender seus mecanismos. De acordo com Barbosa (2004), indivíduos ansiosos tendem a esquivar-se de situações que evoquem ansiedade. Assim, a esquiva é um comportamento natural, fruto dos reforçadores liberados pelo contexto sócio-verbal. Dessa maneira, respostas de fuga/esquiva caracterizam situações que podem ser evitadas, ou seja, controladas. Porém, a função de esquiva, de acordo com Zamignani e Banaco (2005), não é a única possível na manutenção de um transtorno de ansiedade, e as consequências que mantém o problema podem ser mais diversas, envolvendo configurações de contingências.

Sendo a ansiedade social enfoque deste presente trabalho, a próxima seção levanta dados sobre a ocorrência, sintomas, desenvolvimento e possível análise funcional para este transtorno.

\section{Ansiedade social}

De acordo com o DSM - V (APA, 2003), o transtorno de ansiedade social (TAS) é aquele em que o indivíduo é ansioso, temeroso ou se esquiva de quaisquer situações sociais que envolvam a possibilidade de uma avaliação negativa, humilhação ou rejeição. Dentre essas situações, pode-se citar um encontro com pessoas que não são familiares, situações em que o indivíduo pode ser observado comendo ou bebendo e situações de desempenho diante de outras pessoas. Assim, a característica essencial do transtorno de 
ansiedade social é um medo ou ansiedade acentuados ou intensos de situações sociais nas quais o indivíduo pode ser avaliado negativamente pelos outros (APA, 2003; D’El Rey, 2001; Valença, 2014).

Comumente denominado como fobia social, o transtorno de ansiedade social é o mais comum entre os transtornos de ansiedade, representando $78 \%$ dos casos, e aparece em terceiro lugar como transtorno psiquiátrico mais frequente (Levitan et al., 2011). A estimativa de prevalência de 12 meses do transtorno de ansiedade social nos Estados Unidos é de 7\%. A prevalência média na Europa é de 2,3\%. Fatores sociodemográficos mostram que a ansiedade social aparece precocemente, tendo início na infância ou adolescência, frequentemente entre 12 e 17 anos. Quanto ao gênero, muitos estudos epidemiológicos apontam para uma maior prevalência em mulheres, inclusive em estudos brasileiros, os quais apresentam uma taxa de prevalência de 6,7\% em mulheres e 4,2\% em homens (Nardi, Quevedo \& Silva, 2014). As taxas de gênero são equivalentes ou um pouco mais altas para indivíduos do sexo masculino nas amostras clínicas, e presume-se que os papéis de gênero e as expectativas sociais desempenham um papel significativo na explicação do maior comportamento de busca de ajuda nesses pacientes (DSM-V).

A idade média de início do transtorno de ansiedade social nos Estados Unidos é 13 anos, e 75\% dos indivíduos têm idade de início entre 8 e 15 anos. O transtorno ocasionalmente emerge de história infantil de inibição social ou timidez nos estudos norte-americanos e europeus. O início também pode ocorrer no princípio da infância. Pode se seguir a uma experiência estressante ou humilhante (p. ex., ser alvo de bullying, vomitar durante uma palestra pública) ou pode ser insidioso, desenvolvendo-se lentamente (APA, 2003). Fatores temperamentais, ambientais, genéticos e fisiológicos também influenciam no risco e prognóstico deste transtorno (APA, 2003). 
Apesar de ser um transtorno bastante prevalente, Liebowitz, Gorman, Fyer e Klein (1985) afirmam que, até pouco tempo, o estudo da ansiedade social era negligenciado por profissionais da área da saúde mental por ser comumente atrelado a pacientes muito tímidos. Segundo Liebowitz et al (1985), grande parte dos pacientes com ansiedade social conviveram anos em silêncio com sua doença, uma vez que, até pouco tempo, ela era considerada como um distúrbio negligenciado pelos profissionais de saúde mental. Porém, é importante ressaltar que a diferença entre o transtorno de ansiedade social e a timidez está no grau de intensidade da ansiedade gerada antes e durante a situação social e no grau de prejuízos que acarretam a vida da pessoa, nas esferas profissional, acadêmica e social (D’El Rey, 2001).

A seguir, são apresentados os critérios diagnósticos estabelecidos pelo DSM - V para o transtorno:

A.Medo ou ansiedade acentuados acerca de uma ou mais situações sociais em que o indivíduo é exposto a possível avaliação por outras pessoas. Exemplos incluem interações sociais (p. ex., manter uma conversa, encontrar pessoas que não são familiares), ser observado (p. ex., comendo ou bebendo) e situações de desempenho diante de outros (p. ex., proferir palestras).

B.O indivíduo teme agir de forma a demonstrar sintomas de ansiedade que serão avaliados negativamente (i.e., será humilhante ou constrangedor; provocará a rejeição ou ofenderá a outros).

C.As situações sociais quase sempre provocam medo ou ansiedade.

D.As situações sociais são eviradas ou suportadas com intenso medo ou ansiedade.

E.O medo ou ansiedade é desproporcional à ameaça real apresentada pela situação social e o contexto sociocultural.

F.O medo, ansiedade ou esquiva é persistente, geralmente durando mais de seis meses. G.O medo, ansiedade ou esquiva causa sofrimento clinicamente significativo ou prejuízo no funcionamento social profissional ou em outras áreas importantes da vida do indivíduo. 
H.O medo, ansiedade ou esquiva não é consequência dos efeitos fisiológicos de uma substância (p. ex., droga de abuso, medicamento) ou de outra condição médica.

I.O medo, ansiedade ou esquiva não é mais bem explicado pelos sintomas de outro transtorno mental, como transtorno de pânico, transtorno dismórfico corporal ou transtorno do espectro autista.

J.Se outra condição médica (p. ex., doença de Parkinson, obesidade, desfiguração por queimaduras ou ferimentos) está presente, o medo, ansiedade ou esquiva é claramente não relacionado ou é excessivo.

\section{Figura 2. Critérios e sintomas do DSM para o TAS.}

Fonte: APA (2014). DSM-V: Manual Diagnóstico e Estatístico de Transtornos Mentais. Porto Alegre: Artmed.

Os indivíduos com transtorno de ansiedade social podem ser inassertivos ou muito submissos ou, com menos frequência, muito controladores da conversa. Podem mostrar uma postura corporal excessivamente rígida ou contato visual inadequado ou falar com voz extremamente suave. Podem ser tímidos ou retraídos e ser menos abertos em conversas e revelar pouco a seu respeito. O rubor é a resposta física característica do transtorno de ansiedade social (APA, 2003). De acordo com o DSM-V, essas características tornam o TAS um dos transtornos que mais acarretam consequências funcionais aos indivíduos acometidos, principalmente durante a adolescência, gerando déficits de desempenho no trabalho e poucas interações sociais.

Sob a ótica comportamental, no TAS os eventos que se tornam aversivos são as críticas ou avaliação de terceiros (Zamignani \& Banaco, 2005). Para compreendermos este fenômeno dentro da análise do comportamento, é necessário relacionar os termos descritivos com os conceitos da área. Neste trabalho, vamos considerar a ansiedade, de modo geral, enquanto uma classe de respostas operantes e respondentes, sob controle de determinados estímulos. Por um lado, as classes respondentes podem ser definidas enquanto respostas eliciadas por um estímulo aversivo, condicionado ou incondicionado 
e, como exemplos, podemos citar taquicardia, sudoreses, rubor facial, tremores etc. Por outro lado, as classes operantes incluem os comportamentos verbais públicos e privados, como por exemplo, falar que está "nervoso" e pensamentos, respectivamente, e comportamento motores públicos, principalmente os de fuga e esquiva (Hessel, Borloti \& Haydu, 2012; Valença, 2014).

Considerando os processos comportamentais envolvidos no conceito de ansiedade, é importante estabelecer como se relacionam com o TAS. Para Valença (2014), os indivíduos que apresentam um padrão de respostas socialmente ansioso estão sob controle de duas variáveis, quais sejam: a) um histórico de punição e reforçamento negativo em contextos sociais de avaliação social negativa, como por exemplo, ter passado por situações de humilhações sociais ou ter sido alvo de críticas ou ridicularizações, e b) contingências sociais aversivas. Dessa forma, entende-se que os comportamentos de fuga e esquiva a situações aversivas como as citadas, tenham sido reforçados e estabelecidos durante a história de vida do indivíduo, e continuam sendo mantidos através da retirada ou adiamentos dos estímulos sociais aversivos (Valença, 2014).

De acordo com Silvares e Meyer (2000), um modelo de análise funcional adequado para o TAS deve considerar os comportamentos que são característicos do transtorno, tais como comportamentos de isolamento social, assertividade, hipersensibilidade à críticas e avaliações, esquiva de situações sociais; os antecedentes possíveis, como ser apresentado a outras pessoas, ser avaliado ou observado, falar em público; e os consequentes, quais sejam a fuga ou esquiva da situação social ou de desempenho.

O trabalho clínico de base analítico-comportamental tem como principal foco a identificação e alteração de fatores ambientais responsáveis pela instalação e manutenção 
dos problemas apresentados pelo cliente como queixa. A identificação da função que o responder do cliente exerce ao interagir com esses fatores ambientais é pré-requisito para a intervenção terapêutica. As respostas que foram traduzidas como foco da queixa, de acordo com essa abordagem, foram selecionadas ao longo de uma história de interação com diferentes fatores do ambiente e podem exercer funções diversas, dependendo do contexto no qual elas são emitidas (Zamignani \& Vermes, 2003)

O levantamento de tais comportamentos, dos antecedentes e consequentes inclui, também, o conhecimento da história de vida de cada indivíduo, para compreender a aquisição dessas classes de resposta, ou seja, é só a partir da análise da história do indivíduo que podemos compreender o desenvolvimento do transtorno e as funções adquiridas pelos estímulos antecedentes e consequentes para ele (Silvares e Meyer, 2000). A compreensão do padrão comportamental presente no TAS é fundamental para que o terapeuta desenvolva uma análise funcional adequada e consiga interferir de maneira eficaz. As intervenções mais utilizadas para o tratamento do TAS, considerando suas vantagens e desvantagens, serão descritas na seção a seguir.

\section{Tratamentos para o Transtorno de Ansiedade Social}

De acordo com D’El Rey e Pacini (2006), um diagnóstico correto de TAS associado com o encaminhamento para um tratamento adequado minimiza os principais sintomas negativos que a ansiedade social impõe aos portadores. Ito, Roso, Tiwari, Kendall e Asbahr (2008), por meio de uma revisão da literatura, afirmam que o diagnóstico e o tratamento desse transtorno são determinados pelo nível de incômodo e pelo prejuízo funcional, e a principal intervenção terapêutica utilizada é a terapia cognitivo-comportamental (TCC), associada ao uso de fármacos (Ito et al., 2008; D'El 
Rey \& Pacini, 2006; Liebowitz, 1999; Zamignani \& Banaco, 2005; Nardi, Quevedo \& Silva, 2014; Muller, Trentini, Zanini \& Lopes, 2015).

Em relação às intervenções farmacológicas, os inibidores seletivos de receptação de serotonina se constituem como uma das principais intervenções (D’El Rey \& Pacini, 2006). Dentre as atuais terapias baseadas em evidências para o tratamento do TAS está a terapia cognitivo-comportamental, a qual segue algumas técnicas padronizadas gerais, como o treino de habilidades sociais e de assertividade, a reestruturação cognitiva para mudança de crenças negativas, o manejo de estresse e relaxamento e a técnica de exposição às situações temidas (Ito et al., 2008; D’El Rey \& Pacini, 2006).

O treino de habilidades sociais tem utilizado como técnicas mais comuns a modelagem pelo terapeuta dos comportamentos do paciente, o ensaio comportamental, o reforçamento social e o treinamento realizado em ambiente fora da sessão. Alguns estudos sobre este treino revelam sua eficácia em relação a tratamentos placebo ou à ausência de tratamento (Argyle, Bryant \& Trower, 1974; Falloon, Lindley \& McDonald, 1977). De maneira geral, o uso das técnicas de treinamento de habilidades sociais é recomendado para pacientes com fobia social, uma vez que tem se mostrado eficaz em reduzir os sintomas de ansiedade nos confrontos intrapessoais (Curran, 1982; Heimberg, Juster, Hope \& Mattia, 1995; Lincoln \& cols., 2003).

A reestruturação cognitiva trata-se de uma série de intervenções baseadas nas teorias e terapias cognitivas de Beck, Emery e Greenberg (1985). Os pacientes são ensinados a identificar os pensamentos ansiógenos, fazer o teste da realidade e corrigir os conteúdos que estão distorcidos e as crenças disfuncionais. Este processo permite que o paciente perceba a hipervalorização negativa que fazia diante de uma situação, além de uma desvalorização de sua capacidade de enfrentamento da situação (Clark \& Wells, 1995). Estudo demonstraram que esta técnica é eficaz no tratamento do TAS, 
especialmente se manejada em conjunto com as técnicas de exposição (Lincoln \& cols., 2003; Lucock \& Salkovskis, 1988; Mattick, Peters \& Clarke, 1989; Mattick \& Peters, 1988; McManus, Clark \& Hackmann, 2000; Taylor \& cols., 1997; Turner, Beidel \& Cooley, 1994).

As técnicas de relaxamento têm por objetivo auxiliar o paciente a controlar seus sintomas fisiológicos antecipadamente, ou após a ocorrência dos eventos temidos. Esta técnica facilitaria a exposição do paciente à situação temida, porém os estudos mostram que não é um exercício eficaz quando praticado de maneira isolada no tratamento de ansiedade social (Jerremalm, Jansson \& Öst, 1986; Öst, Jerremalm \& Johansson, 1981; Otto, 1999).

A técnica de exposição com prevenção de respostas às situações temidas é uma das mais conhecidas e utilizadas em TCC para o tratamento do TAS. Nesta técnica, o paciente deve imaginar (imaginação enquanto exposição) ou vivenciar (exposição ao vivo) as situações temidas. Juntamente com o terapeuta, o paciente constrói uma lista de situações temidas, em ordem crescente quanto ao nível de adversidade das situações (Wolpe, 1973). No estágio inicial do tratamento, as situações são enfrentadas em companhia do terapeuta, até que ocorra a habituação da ansiedade. Após exposições repetidas e prolongadas da situação temida e, quando a situação não eliciar mais altos níveis de ansiedade, passa-se para o próximo item da lista. E assim, o processo continua até que todas as situações da lista sejam vivenciadas. Vários estudos relataram a eficácia da exposição no tratamento para o TAS (Fava, Grand, Rafanelli, Conti \& Belluard, 2001; Heimberg, Dodge \& Hope, 1990; Lincoln \& cols., 2003; Mattick, Peters \& Clarke, 1989; Mattick \& Peters, 1988; Mersch, 1995; Newman, Hofmann, Trabert, Roth \& Taylor, 1994; Shaw, 1979). 
Apesar do uso da TCC ser amplamente difundido como tratamento terapêutico nos casos de TAS, Zamignani e Banaco (2005) têm questionado algumas das técnicas utilizadas como estratégia principal, como o procedimento de exposição com prevenção de respostas. Essa técnica exige que o cliente tenha contato com os estímulos aversivos para que ocorra uma habituação e esse procedimento pode fazer com que a própria situação de terapia adquira propriedades aversivas. Assaz e Oshiro (2017) também afirmam que muitas das terapias de exposição enfrentam obstáculos no manejo clínico. Os autores citam dois principais problemas das técnicas de exposição: a) a pouca resposta dos pacientes ou o abandono a este tipo de técnica, conforme pesquisas, e b) a crença, por parte de psicólogos clínicos, de que a terapia baseada em exposição é perigosa para o cliente, podendo fazer com que este reviva alguns traumas, evidenciando sintomas clínicos. Assim, tal manejo poderia ser considerado como estressante e antiético, tanto para o cliente quanto para o terapeuta (Assaz \& Oshiro, 2017).

Considerando, portanto, uma avaliação que leve em conta critérios funcionais, o tratamento escolhido deve ser governado pelos mesmos princípios, qual seja, aquele que busque mudar a função dos comportamentos de esquiva de uma situação ansiógena (Lopez-Bermudez \& Calvillo, 2010). Neste sentido, terapias que tenham como enfoque a análise funcional dos comportamentos prejudiciais ao indivíduo no contexto em que ele vive, podem ser uma alternativa ao tratamento de transtornos de ansiedade, como por exemplo, as terapias contemporâneas de terceira onda. Na seção a seguir, será descrita a terapia de terceira onda denominada de Psicoterapia Analítica Funcional (Kohlenberg \& Tsai, 2001), a qual será utilizada no presente trabalho enquanto intervenção. 


\section{Terapias de Terceira Onda: A Psicoterapia Analítica funcional (FAP)}

A Psicoterapia Analítica Funcional (FAP) é uma forma de intervenção psicoterápica que integra a chamada "terceira geração" das terapias comportamentais, um movimento que surgiu para enfatizar a importância da relação terapêutica enquanto mecanismo de mudança nos processos e intervenções clínicas (Hayes, 2004). Considerando a necessidade de melhor compreender a relação que se estabelece entre terapeuta e cliente, além dos mecanismos de mudança clínica que a relação terapêutica pode provocar, Kohlenberg e Tsai (2001) desenvolveram a Psicoterapia Analítica Funcional (do inglês Functional Analytic Psychotherapy - FAP). A FAP tem como modelo filosófico o behaviorismo radical (Skinner, 1953) e os fundamentos da análise experimental do comportamento, e como método científico a terapia derivada da análise funcional skinneriana. Essa psicoterapia tem como foco a interação entre terapeuta e cliente, com o terapeuta respondendo contingentemente aos comportamentos emitidos em sessão pelo cliente, no "aqui e agora” (Tsai, Kohlenberg, Kanter, Kohlenberg, Follette \& Callaghan, 2011). Para a FAP, a maneira como um indivíduo se comporta em ambiente externo é semelhante à maneira como ele se comporta em sessão, ou seja, os comportamentos-alvo do cliente são evocados também durante a sessão terapêutica, na relação terapeuta-cliente.

Assim, esta psicoterapia funciona como uma estratégia terapêutica focada na análise de contingências de comportamentos evocados no ambiente terapêutico (Kohlenberg \& Tsai, 2001). Tais comportamentos são classificados de Comportamentos Clinicamente Relevantes (CRBs) e são divididos em três classes: os comportamentos problemas do cliente emitidos em sessão (CRB1), os comportamentos de melhora do cliente em sessão (CRB2) e os comportamentos de interpretação do cliente sobre seu comportamento (CRB3). Os objetivos dessa psicoterapia são aumentar a frequência dos 
comportamentos de melhora do cliente (CRB2) em detrimento da diminuição da frequência dos comportamentos problema do cliente (CRB1). Além disso, é importante que o cliente aprenda a generalizar os progressos obtidos em sessão para sua vida fora do consultório (Kohlenberg \& Tsai, 2001). Para nortear o uso dessa psicoterapia e orientar o comportamento dos terapeutas, estes autores criaram cinco regras de utilização da FAP: Regra 1) estar atento aos CRBs - essa regra diz respeito à atenção do terapeuta aos comportamentos clinicamente relevantes do cliente em sessão; Regra 2) evocar os CRBs - essa regra diz respeito à importância do terapeuta tentar criar em sessão situações que possibilitem a ocorrência dos comportamentos clinicamente relevantes do cliente; Regra 3) reforçar os CRB2s - essa regra tem por objetivo o responder contingente do terapeuta, visando o aumento da frequência dos CRB2s e CRB3s e a diminuição da frequência dos CRB1s; Regra 4) o terapeuta deve estar atento aos efeitos de seu comportamento sobre o cliente - essa regra diz respeito ao impacto das respostas do terapeuta sobre o comportamento do cliente, afim de identificar se os CRBs estão sendo consequenciados de forma adequada; e a Regra 5) promover estratégias de generalização - essa regra visa ensinar ao cliente interpretar e generalizar seus comportamentos dentro de sessão para fora da sessão, permitindo que o cliente estabeleça paralelos entre estes comportamentos.

No caso do TAS, a própria situação de terapia pode ser tida como uma exposição social e de desempenho e evocar os sintomas de ansiedade desses clientes, caracterizando um CRB1. A relação terapêutica, por si só, pode provocar no cliente sensação de auto avaliação, autocríticas e esquiva de intimidade. Levando-se em conta, portanto, que a FAP tem como ênfase os problemas interpessoais e, uma vez que, de maneira natural, a relação terapêutica seja um estímulo poderoso para eliciar e evocar esquiva de relações interpessoais, problemas de intimidade, ansiedade, medo e outras dificuldades de cunho interpessoal, esta terapia pode se tornar uma opção para intensificar o tratamento deste 
tipo de transtorno ou até mesmo oferecer uma alternativa para clientes resistentes aos tratamentos comumente recomendados. A seguir, estão descritos estudos que utilizaram a FAP como intervenção em transtornos de ansiedade, revelando a hipótese de que esta psicoterapia pode trazer bons resultados em casos de ansiedade social.

\section{FAP como tratamento para transtornos de ansiedade}

Considerando o TAS enquanto um dos transtornos psicológicos mais prevalentes na clínica, atrás da depressão maior e da dependência de álcool (Valença, 2014), é fundamental a realização de mais estudos sobre o tema, especialmente em termos de intervenção. De acordo com Mangabeira, Kanter e Del Prette (2012), existe uma importante diversidade de estudos com resultados eficazes no uso da FAP em diferentes transtornos, especialmente em relação àqueles com comprometimento interpessoal. Além disso, outros estudos apontam que a FAP produz melhoras significativas na qualidade de vida e funcionamento nas relações interpessoais dos clientes (Kohlenberg, Kanter, Bolling, Parker, \& Tsai, 2002; Callaghan, Summers \& Weidman, 2003; Oshiro, Kanter \& Meyer, 2012; Lima, 2017; Aranha, no prelo; Vartanian, 2017; Moreira, 2017).

Para o presente estudo, até o momento, não foram encontradas pesquisas experimentais que avaliassem a eficácia da FAP em indivíduos com ansiedade social, mas estudos que levantassem a hipótese de que este manejo poderia trazer benefícios para os indivíduos dessa população. Porém, existem importantes estudos que analisam o tratamento da FAP em outros transtornos de ansiedade, como o transtorno obsessivo compulsivo, transtorno de pânico sem agorafobia e o transtorno de pânico com agorafobia

(Mendes \& Vandenberghe, 2009; Vandenberghe, 2007; Zamignani, 2001; Brandão, Oshiro \& Pezzato, 2012; Manduchi \& Schoendorff, 2012; Lopez-Bermudez, Ferro \& Calvillo, 2010) e que podem fornecer dados importantes para o presente estudo, 
considerando as semelhanças entre os transtornos de ansiedade, a escolha da FAP enquanto tratamento clínico, as dificuldades encontradas e os resultados.

Mendes e Vandenberghe (2009), em seus estudos sobre o transtorno obsessivo compulsivo (TOC) e a relação terapeuta -cliente, afirmam que a FAP é uma terapia que pode se diferenciar dos tratamentos tradicionais de transtorno de ansiedade justamente por se basear nas mudanças obtidas no relacionamento interpessoal estabelecido entre terapeuta e cliente em sessão, propiciando uma oportunidade de aprendizagem ao vivo. Ainda que o TOC não seja um transtorno de ordem interpessoal, à primeira vista, os resultados desse estudo mostraram que a FAP é eficiente ao considerar o relacionamento terapêutico e as oportunidades de aprendizagem ao vivo que ocorrem no contexto da relação terapêutica, argumentando que tais técnicas podem ser alternativas ou complementares aos tratamentos usualmente utilizados. Além disso, estes autores levantam a possibilidade de um estudo da ansiedade social com FAP, por afirmarem que o cliente com ansiedade social se sente criticado pelas interpretações do terapeuta e a FAP fornece a oportunidade de aprender ao vivo com esta situação, ajudando o cliente a enfrentar e superar os problemas cotidianos.

No estudo sobre transtorno de pânico sem agorafobia, Lopez-Bermudez, Ferro e Calvillo (2010) apontaram que o uso de práticas convencionais no tratamento de transtornos de ansiedade, como diferentes tipos de relaxamento, treino de simulação interoceptiva e métodos de respiração do diafragma, deixaram a cliente ainda mais nervosa e depressiva por notar que não conseguia realizá-las. A seguir, observaram que a audiência não punitiva foi uma das funções iniciais do terapeuta que se manteve durante todo o tratamento e se tornou essencial para a cliente nesse caso, com o terapeuta se concentrando na maneira como ela se sente, ao invés de tentar eliminar sentimentos. Zamignani e Banaco (2005) também apontaram a importância de uma relação terapêutica 
baseada em audiência não punitiva para produzir maior adesão ao tratamento clínico. A generalização de comportamentos de dentro e fora da clínica também se demonstrou eficaz, pois ajudou o cliente a estabelecer regras mais apropriadas e identificar as variáveis de controle sobre o que de fato aconteceu. A qualidade da relação estabelecida entre terapeuta e cliente também foi apontada como um indicador importante nos resultados da intervenção da FAP no transtorno de pânico sem agorafobia (LopezBermudez, Ferro \& Calvillo, 2010).

Em casos de transtorno de pânico com agorafobia, resultados semelhantes no uso da FAP também foram encontrados. Neste estudo, Pezzato, Brandão e Oshiro (2012) apontam a possibilidade da generalização nos tratamentos de transtornos de ansiedade, uma vez que estes transtornos apresentam como padrão comportamental comum a esquiva fóbica. A esquiva fóbica pode dificultar o uso de estratégias comumente utilizadas no tratamento desses casos, como procedimentos comportamentais ou cognitivo-comportamentais de exposição a situações aversivas, dificultando a adesão ao tratamento. Assim, esses autores enxergaram na intervenção FAP a oportunidade de auxiliar no manejo da esquiva do cliente ao tratamento psicoterápico, e os resultados se demonstraram conclusivos quanto à adoção da FAP para o aumento da eficácia das terapias empiricamente baseadas.

Um ponto em comum encontrado nesses estudos e apontado como possível obstáculo no tratamento de transtornos de ansiedade é a dificuldade de adesão ao tratamento. De acordo com Zamignani e Banaco (2005), conforme já dito, a natureza aversiva dos padrões comportamentais nesses transtornos, por si só, pode levar a uma esquiva do processo terapêutico e a dificuldades na adesão ao tratamento. Uma possível solução para aumentar a eficácia dos tratamentos em termos de adesão, é através de uma análise da ansiedade baseada no maior número de variáveis envolvidas (Zamignani \& 
Banaco, 2005). Ainda, considerando a natureza da FAP enquanto psicoterapia voltada para a criação de relações interpessoais íntimas e de uma aliança terapêutica efetiva que propicie mudanças e aprendizagens em sessão (Kohlenberg \& Tsai, 2001), a FAP pode ser indicada para casos que não aderem ou não respondem aos tratamentos tradicionais, especialmente para clientes com dificuldade de estabelecer relacionamentos interpessoais íntimos, como a ansiedade social (Follete, Naugle \& Callaghan, 1996).

Malerbi, Savoia e Bernik (2000) realizaram um estudo sobre a aderência ao tratamento em fóbicos sociais no qual afirmam que a ansiedade social é um transtorno que, devido a suas características, apresenta diversas razões para o baixo nível de adesão ao tratamento, e um desses fatores é o comportamento de esquiva do contato social. A pesquisa mostra relações de baixa aderência associada a características do cliente, como a idade (a aderência tende a aumentar com a idade), tipos de tratamento (quanto mais complexo o tratamento, menor a aderência), profissionais da saúde (quanto maiores as habilidades do profissional em comunicar-se com o paciente e informá-lo sobre o transtorno e o processo de tratamento, maior a aderência e melhores serão os resultados). Outro aspecto importante concluído pelos autores é que as melhores medidas já encontradas para aumentar a aderência desses clientes ao tratamento é o estabelecimento de uma interação sólida e construtiva entre o profissional e o paciente, na qual o terapeuta deve, sempre que possível, informar ao cliente de suas melhoras, adequando a percepção com a evolução terapêutica, visto que os dados desse estudo mostraram que grande parte dos abandonos deveu-se à falta de motivação dos clientes e/ou à falta de percepção dos resultados do tratamento aplicado (Malerbi, Savoia \& Bernik, 2000). Logo, por apresentar como base de sua terapia a criação de uma relação íntima e segura, a FAP pode fornecer a condição essencial para o estabelecimento e manutenção da adesão do cliente ao tratamento. 


\section{Objetivos}

Dessa maneira, o presente estudo tem por objetivo analisar o efeito da FAP enquanto intervenção para indivíduos com ansiedade social, possibilitando melhores condições no processo terapêutico e melhora na qualidade de vida de clientes com um transtorno clínico com grande prevalência na sociedade e que provoca grandes prejuízos funcionais e comprometimentos psicossociais. Além disso, esta pesquisa pretende mostrar a generalidade da FAP em diferentes populações, replicando os dados da tese de doutorado de Oshiro (2011) e Oshiro, Kanter \& Meyer (2012).

\section{MÉTODO}

\section{Participantes}

Os participantes foram uma terapeuta (pesquisadora) com experiência clínica e supervisão em FAP, três clientes adultos e três aferidores de concordância. Os participantes foram contatados em parceria com o grupo de pesquisa APORTA, vinculado ao Programa de Ansiedade do IPq (Instituto de Psiquiatria) da Faculdade de Medicina da USP. A escolha dos participantes foi feita por meio de uma triagem baseada na inclusão dos participantes nos critérios do Instrumento M.I.N.I. (Mini International Neuropsychiatric Interview 5; Amorim, 1998) para o TAS, que já tenham sido diagnosticados para o transtorno e com idade mínima de 18 anos. Não foram selecionados sexo, escolaridade ou queixas dos clientes. Como critérios de exclusão, não foram selecionados participantes que apresentassem outras comorbidades, com exceção de depressão, uma vez que este diagnóstico aparece bastante em casos de TAS, de acordo com a literatura (D’El Rey, 2001). Além disso, por terem sido encaminhados pelo grupo APORTA, os participantes já haviam passado por uma triagem inicial, não apresentando outros tipos de transtornos e sendo diagnosticados com ansiedade social. 
O participante 1, Rodolfo (nome fictício), iniciou a terapia aos 36 anos, era concursado e começou a trabalhar um mês após o início da terapia. Morava com os pais e nunca havia tido um relacionamento amoroso. De acordo com a conceituação de caso, apresentava dificuldades em criar relacionamentos interpessoais e enfrentar conflitos. Foi diagnosticado com ansiedade social aos 26 anos.

O participante 2, Walter (nome fictício), iniciou a terapia aos 22 anos, estudava para o vestibular de medicina, por conta própria e, ao final da pesquisa, foi aprovado no vestibular para este curso. De acordo com a conceituação de caso, apresentava dificuldades em estabelecer relações íntimas e demonstrar vulnerabilidades. Fazia acompanhamento psiquiátrico no IPq e utilizava medicação (quetiapina).

O participante 3, Murilo (nome fictício), iniciou a terapia aos 20 anos, morava com os pais e não estudava ou trabalhava. De acordo com a conceituação de caso, apresentava dificuldades em estabelecer vínculos e excesso de julgamentos a seu respeito.

Os aferidores de concordância foram três psicólogos formados, integrantes do grupo de pesquisa da qual a terapeuta/pesquisadora faz parte, tendo acompanhado as discussões em supervisão dos casos desta pesquisa. Os aferidores foram treinados para o uso dos instrumentos de medidas utilizados nesse estudo, por meio da leitura do Sistema de categorização da Psicoterapia Analítica Funcional (Functional Analytic Psychotherapy Rating Scale - FAPRS; Callaghan \& Follette, 2008), da conceituação de caso de cada participante e de uma sessão teste categorizada pela pesquisadora.

\section{Ambientes e materiais}

Os atendimentos foram realizados em uma sala da Clínica-escola Durval Marcondes do Instituto de Psicologia da Universidade de São Paulo, na qual as sessões foram gravadas por meio de aparelhos gravadores e/ou celulares. Para o tratamento dos 
dados, foram utilizados um computador e pendrives com as gravações de áudio das sessões.

\section{Instrumentos}

1) M.I.N.I (Mini International Neuropsychiatric Interview 5; traduzido por Amorim, 1998).

O M.I.N.I. é uma entrevista diagnóstica padronizada breve (15-30 minutos), compatível com os critérios do DSM-IV e da CID-10, destinada à utilização na prática clínica e na pesquisa em atenção primária e em psiquiatria, podendo ser utilizada por clínicos após um treinamento rápido e formação breve. Esta entrevista explora os principais Transtornos Psiquiátricos do Eixo I do DSM IV, sendo organizada em módulos independentes, de maneira a otimizar a sensibilidade do instrumento. A prioridade da entrevista é a identificação dos transtornos atuais. A avaliação das questões é dicotômica ( $\operatorname{sim}$ ou não).

2) Sistema de categorização da Psicoterapia Analítica Funcional (Functional Analytic Psychotherapy Rating Scale - FAPRS, Callaghan \& Follette, 2008) adaptado:

O FAPRS é um instrumento desenvolvido para categorizar as gravações de vídeos e áudios das sessões de terapia baseadas na teoria e procedimentos propostos pela FAP. O objetivo dessa categorização é registrar e analisar de maneira funcional os comportamentos do cliente e terapeutas em sessão, fornecendo a oportunidade de observar possíveis mudanças de comportamentos. O registro ocorre sequenciando as respostas verbais dos categorizados, possibilitando a relação estabelecida entre as respostas e consequências do terapeuta sobre as respostas do cliente. 
3) Outcome Questionnaire- OQ-45 (traduzido e adaptado por Carvalho \& Rocha, 2009, do original Lambert \& cols. 2004)

O OQ-45 é um instrumento voltado para avaliar os progressos do cliente durante o processo de psicoterapia, de maneira repetida. Por não se tratar de um instrumento teoricamente orientado, pode ser aplicado por psicoterapias diferentes. O instrumento é composto por 45 itens, dos quais 25 relacionam-se ao desconforto subjetivo, 11 a relacionamentos interpessoais e 9 a desempenhos sociais. Esses itens são respondidos de acordo com a escala Likert, de cinco pontos, com a variação de "nunca" até "quase sempre".

Em termos de pontuação, cada categoria apresenta diferentes escores. Para que se identifique uma mudança clínica significativa, tem de haver uma diminuição do escore $\geq 10$ para os sintomas de desconforto subjetivo, $\geq 8$ para sintomas de relacionamento interpessoais, $\geq 7$ para sintomas de desempenho do papel social e $\geq 14$ para o escore total.

4) Escala de Depressão de Beck (BDI - Beck Depression Inventory, BDI, BDIII; traduzido e adaptado por Cunha, 2001).

O BDI é um instrumento no formato de questionário cujo objetivo é avaliar o grau de severidade dos episódios depressivos na última semana que se passou. Por meio dos 21 itens, com quatro possibilidades de respostas cada, variando de acordo com a intensidade, o indivíduo seleciona aqueles relacionados com sintomas depressivos, como desesperança, irritabilidade, culpa ou sentimentos de punição, além de sintomas físicos próprios da depressão. 
5) LSAS (Liebowitz Social Anxiety Scale; traduzido por Lotufo-Neto, 2000).

A LSAS foi a primeira escala hetero-administrada para a avaliação do TAS. Tem como propósito avaliar situações de desempenho e de interação social, das quais os indivíduos com TAS evitam ou temem. É composta por 24 itens, divididos em duas subescalas: a) interação social (11 itens) e, b) desempenho (13 itens), os quais são avaliados através da escala Likert de quatro pontos (zero a três). O escore total é a somatória das sub-escalas.

6) SPIN (Social Phobia Inventory; traduzido e adaptado para o português por Crippa, Graef, Zuardi, Hetem, Busatto \& Loureiro, 2003).

O SPIN é um instrumento composto por 17 itens, os quais exploram três importantes critérios que definem a fobia social: o medo, a esquiva das situações e os sintomas de desconforto físico, englobando tanto situações de desempenho, como de interação social. O indivíduo deverá indicar, para cada item, o quanto as situações/sintomas mencionados o incomodaram na última semana, que variam, gradativamente, de "nada", "um pouco", "moderadamente", "bastante" e “extremamente". A pontuação do instrumento varia de 0 a 4 , para cada uma das gradações. A pontuação total irá variar de 0 a 68 .

\section{Procedimento}

O presente estudo foi submetido à análise da Comissão de Ética e aprovado em novembro de 2017 (CAAE: 78127317.0.0000.5561). Antes do início do processo terapêutico, os participantes foram selecionados por meio de uma parceria estabelecida com a APORTA, associação vinculada ao Instituto de Psiquiatria (IPq-USP). A pesquisadora entrou em contato telefônico com um dos pesquisadores da Associação, 
apresentou a pesquisa e participou de um mini-curso sobre o instrumento M.I.N.I. Assim, teve acesso a uma lista de triagem de participantes que já estiveram em outras pesquisas e entrou em contato com os participantes. Os selecionados passaram por uma triagem e entrevista diagnóstica com o uso do M.I.N.I. (Mini Neuropsychiatric Interview 5) e, uma vez correspondendo aos critérios de inclusão para o estudo, foram informados a respeito da pesquisa e assinaram o Termo de Consentimento Livre e Esclarecido (TCLE) para Participantes fornecendo a permissão para a utilização dos dados obtidos para fins de pesquisa.

Para avaliar os efeitos da FAP sobre os sintomas do Transtorno de Ansiedade Social e investigar o processo de mudança clínica envolvido nas intervenções, a metodologia utilizada foi o delineamento experimental de caso único de linha de base múltipla. O delineamento experimental de caso único considera o estudo e análise do comportamento de cada organismo individualmente, no qual as diferenças de história de vida e outras relativas aos contextos são respeitadas (Sidman, 1960). Assim, considerase que o participante é o seu próprio controle, uma vez que são tomadas medidas repetidas do mesmo participante ao longo do tempo. Este tipo de delineamento permite observar uma relação direta de causa e efeito entre as variáveis dependentes (mudanças no comportamento) e independentes (intervenções). É possível identificar, portanto, se a mudança nas variáveis dependentes ocorre devido à introdução das variáveis independentes. Para isso, são estabelecidas mais de uma linha de base (condições controle), uma para cada participante, nas quais as variáveis independentes são introduzidas em momentos distintos em cada uma das linhas de base (Sampaio et al, 2008). De acordo com Kazdin (1982), uma vantagem deste delineamento é que o efeito da intervenção é demonstrado quando ocorre mudança no comportamento dos participantes que recebem a intervenção e manutenção dos níveis da linha de base para 
os participantes para os quais a intervenção não tenha sido implementada, testando a validade ou não da intervenção introduzida e sua influência com o tempo de aplicação. Assim, esse tipo de arranjo experimental, a linha de base múltipla, foi uma importante escolha metodológica, uma vez que os indivíduos com ansiedade social são bastante sensíveis às mudanças de comportamento do terapeuta e, uma retirada da intervenção, por exemplo, poderia causar impactos negativos e até ser danosa eticamente aos participantes.

Este estudo foi composto por duas fases: A (linha de base) e B (introdução da FAP), e uma sessão de seguimento após um mês do encerramento da terapia, como exemplificado pela Figura 3. Logo em seguida, as fases são descritas detalhadamente.

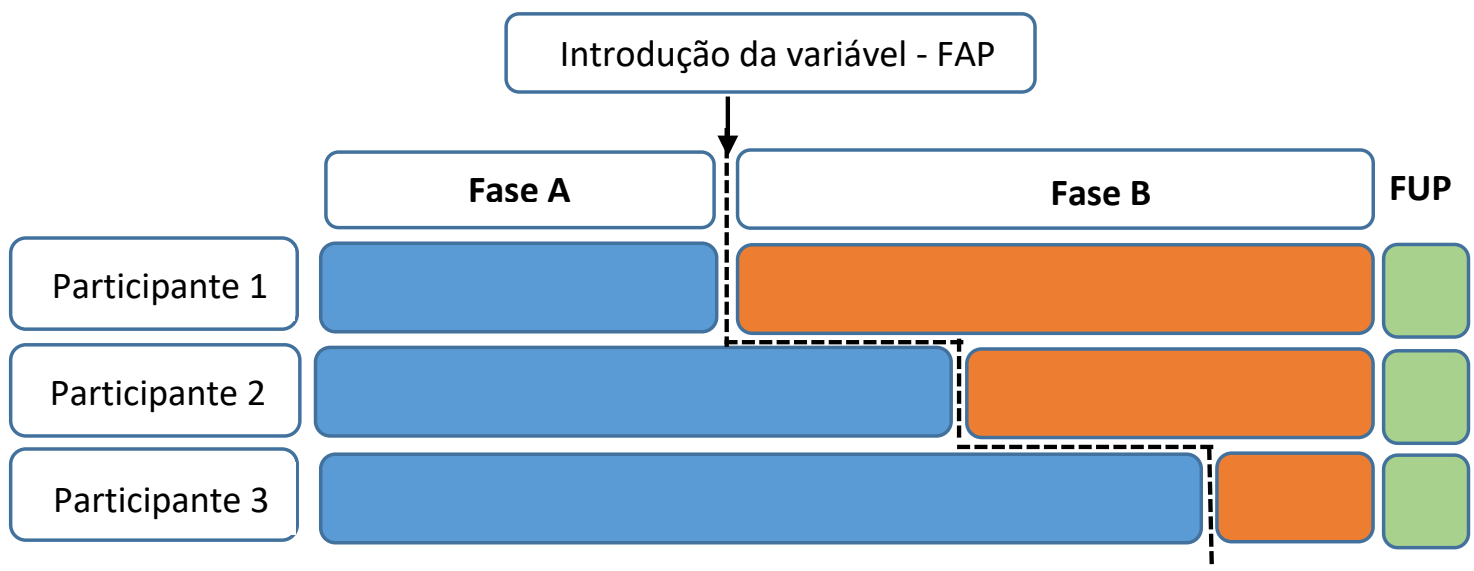

Figura 3: Delineamento experimental de caso único de linha de base múltipla entre participantes. Legenda: Fase $\mathrm{A}=$ linha de base; Fase $\mathrm{B}=$ introdução da variável independente (FAP) e, FUP = sessão de seguimento (follow-up).

\section{Fase A: Linha de Base:}

A Fase A, a linha de base, teve como objetivo montar as conceituações dos casos, identificando os possíveis CRBs para cada participante e, a sua duração, foi diferente para cada cliente (a saber, os participantes 1, 2 e 3, respectivamente, fizeram 10, 17 e 19 sessões de linha de base; ver Figura 3). A diferença no número de sessões desta fase para 
cada participante é justamente fruto do arranjo experimental escolhido, a linha de base múltipla, descrita no início do procedimento. Ou seja, a mudança para a Fase B se deu em diferentes momentos para cada participante. Nesta fase, foram utilizadas intervenções psicológicas pertencentes ao repertório interpessoal básico do terapeuta, como a validação, a escuta empática, o encorajamento e apoio ao cliente para explorar e expressar as experiências e emoções (fatores comuns). A limitação dessa fase estava na retirada de quaisquer princípios interventivos, com exceção da análise de contingências externas, ou seja, mantendo-se prioritariamente os fatores comuns (Wampold, 2015). O foco também era o estabelecimento de um relacionamento terapêutico forte o suficiente para diminuir as chances de desistência e aumentar as chances de adesão à terapia. O sistema FAPRS foi utilizado para a categorização da interação terapeuta e cliente e, no início de cada sessão, os participantes responderam ao OQ-45, BDI, LSAS e SPIN para a coleta de dados e controle dos comportamentos que seriam avaliados antes, durante e após a terapia. Assim que a conceituação do caso foi definida, os critérios de estabilidade (variação de $10 \%$ para cima ou para baixo das variáveis dependentes) ou a tendência dos dados (tendência oposta ao esperado para a próxima fase) foram utilizados para a mudança de fase. Vale lembrar que, de acordo com Sidman (1960), a estabilidade é um padrão que mostra pouca variação das variáveis dependentes ao longo do tempo durante determinado período. Para a análise de dados, foram selecionadas cinco sessões desta fase para cada participante, sendo duas sessões logo de início da fase, uma sessão intermediária sorteada e duas sessões que antecederam a mudança para a Fase B. Esta escolha metodológica se deu na tentativa de monitorar tendência e estabilidade das variáveis dependentes na totalidade da fase, diminuindo o risco de sortear apenas sessões iniciais ou finais da linha de base. O critério para análise de cinco sessões foi embasado no estudo de Kratochwill et al. (2013). 


\section{Fase B: Introducão da variável independente FAP:}

Cada participante iniciou a Fase B em períodos diferentes da terapia. Como já discorrido acima sobre o motivo desta diferença, a introdução da VI (FAP) se deu na sessão 11 para o participante 1, sessão 18 para participante 2 e sessão 20 para participante 3 (ver Figura 3). Nesta fase, priorizou o uso das cinco regras descritas por Kohlenberg e Tsai (2001) e o principal objetivo foi o responder contingente do terapeuta ao CRB2 de cada participante. O Sistema FAPRS categorizou os comportamentos da interação terapeuta-cliente e os instrumentos OQ-45, BDI, LSAS e SPIN foram respondidos no mesmo formato da fase anterior. O mesmo critério para o número de sessão analisado (cinco) foi seguido.

\section{Sessão de seguimento (FUP):}

Para avaliar as possíveis mudanças ocasionadas pelo fim da terapia e a manutenção dos resultados obtidos com o delineamento, quatro semanas após o término da Fase B, sem qualquer tipo de intervenção e aplicação de instrumentos neste intervalo, foi feita uma sessão de seguimento, na qual foram aplicados o OQ-45, BDI, LSAS e SPIN, e utilizado o FAPRS para a análise das falas da terapeuta e clientes.

\section{Forma de análise dos resultados}

Para a análise dos dados, foram realizadas transcrições e categorizações das sessões, cálculo de concordância e tabulação dos dados. Três alunos de psicologia, com contrato de sigilo, transcreveram as sessões, e a terapeuta-pesquisadora categorizou todas as sessões. Apesar da pesquisadora ter ocupado o papel de terapeuta e categorizadora principal, tal decisão foi tomada devido à dificuldade em estabelecer uma equipe de trabalho com psicólogos treinados para a categorização das sessões, podendo prejudicar 
o andamento na pesquisa, no que diz respeito ao compromisso e prazos, podendo acarretar em maiores prejuízos para o delineamento e um viés maior no resultado da pesquisa.

Para a aferição, foram utilizados três psicólogos do grupo de pesquisa, conforme mencionado na seção "participantes", os quais categorizaram as sessões por meio do FAPRS - $20 \%$ das sessões foram categorizadas pela pesquisadora em cada fase do procedimento, de acordo com o recomendado por Kratochwill et al. (2013). Os níveis de concordância são avaliados como suficientes se a concordância percentual bruta atingir o mínimo de $80 \%$ ou o índice Cohen Kappa atingir o mínimo de 0,6 (Kratochwill et al. 2013). O treino dos aferidores será descrito mais adiante.

Para verificar os efeitos da FAP no tratamento de indivíduos com ansiedade social, foram analisados a frequência de CRBs ao longo das fases e as pontuações dos instrumentos utilizados (OQ-45, BDI, SPIN e LSAS). Também foram efetuadas análises qualitativas entre os resultados dos instrumentos e os resultados do FAPRS. Ainda, todos estes resultados foram dispostos em gráficos. De acordo com Kratochwill et al. (2013), tal disposição é a maneira mais comum e eficaz de analisar os resultados entre a relação da VI e VD nos estudos de caso único.

\section{Análise dos aspectos éticos}

Os aspectos éticos foram considerados e conduzidos nos termos da Resolução 466, do Conselho Nacional de Saúde, a qual trata de pesquisas envolvendo seres humanos. O estudo foi submetido à Comissão Ética e teve início apenas após o recebimento de sua aprovação (CAAE: 78127317.0.0000.5561). Em seguida, os participantes selecionados foram informados a respeito da pesquisa e receberam o Termo de Consentimento Livre e Esclarecido para Participantes, fornecendo a utilização dos dados obtidos para fim de pesquisa, se o desejarem. 
A terapeuta-pesquisadora assinou o Termo de Compromisso e Responsabilidade. Na ocasião do uso dos dados da pesquisa, a identificação dos clientes não foi divulgada. A terapeuta-pesquisadora foi responsável, também, pelo andamento e aplicação dos procedimentos da pesquisa, além da avaliação do bem-estar dos participantes durante a fase de coleta de dados.

\section{Aferição de concordância}

Para a aferição de concordância, três aferidores passaram por um treino de aferição, o qual consistiu na leitura do instrumento FAPRS, da conceituação de caso dos três participantes, do resumo das regras utilizadas nesta pesquisa e no acompanhamento da discussão dos casos nas reuniões de pesquisa, tomando-se o cuidado para que os três aferidores estivessem o máximo possível alinhados, como explicado na seção "Métodos". Conforme Kratochwill et al. (2013), para aumentar a validade interna do estudo de caso único, devem ser calculadas as concordâncias de, pelo menos, $20 \%$ das sessões categorizadas pela pesquisadora, o que correspondeu a duas sessões de cada fase do experimento (Fase A e Fase B) para cada participante: sessões 6 e 11, para Rodolfo; sessões 6 e 34, para Walter; e sessões 18 e 28, para Murilo. Assim, para o cálculo do índice de concordância foram utilizadas duas medidas que, de acordo com os autores, são as mais comuns: índice de concordância percentual e índice do coeficiente Kappa de Cohen.

O índice de concordância percentual é produzido por meio da seguinte expressão matemática: $\mathrm{n}^{\mathrm{o}}$ de categorias concordantes entre pesquisadora e aferidor X $100 / \mathrm{n}^{\circ}$ de turnos da sessão, e representa o cálculo bruto da porcentagem de categorias concordantes entre pesquisadora e aferidor em cada sessão. Para atingir os critérios de validade do estudo de caso único proposto por Kratochwill et al. (2013), é necessária uma 
porcentagem mínima de 0,80 de concordância. Os índices de concordância percentual entre a pesquisadora e os aferidores encontram-se na Tabela 1, abaixo:

Tabela 1.

Índice de concordância percentual obtido entre a pesquisadora-terapeuta e os aferidores de concordância em cada sessão categorizada pelo FAPRS

\section{Sessões de aferição por fases experimentais}

A B $\quad$ Média

\begin{tabular}{lcccc}
\hline Aferidor 1 & $\%$ & $78,81-85,12^{*}$ & 83,39 & 82,44 \\
\hline Aferidor 2 & $\%$ & 67,43 & 59,07 & 63,25 \\
\hline Aferidor 3 & $\%$ & - & 82,60 & 82,60
\end{tabular}

*Duas sessões da Fase A foram aferidas por Aferidor 1.

Nota-se que em duas das três aferições a concordância atingiu o critério mínimo necessário. Os aferidores 1 e 3 obtiveram resultados próximos entre si, com média de concordância de $82,44 \%$ e $82,60 \%$, respectivamente, e o aferidor 2 foi o que ficou menos próximo de atingir a concordância com a pesquisadora-terapeuta, com média de $63,25 \%$. Este resultado revela que a experiência do aferidor com a FAP e com o instrumento FAPRS interfere significativamente no resultado de concordância, uma vez que os aferidores 1 e 3 tinham maior aproximação com a psicoterapia do que o aferidor 2 . Além disso, a boa concordância dentre dois dos três aferidores com a pesquisadora-terapeuta, revela a importância de uma conceituação de caso detalhada e seguindo os moldes propostos pela FAP, conforme efetuada nesta pesquisa.

Uma variável importante de ser levantada é o que o aferidor 2 era bastante inexperiente quanto ao instrumento FAPRS e, quando da análise da pesquisadoraterapeuta, percebeu-se falhas na aferição quanto a regras básicas de hierarquia do instrumento, o que também pode ser explicado por uma falha no treino de aferição. Com 
o intuito de verificar a diferença no cálculo de concordância, a pesquisadora-terapeuta corrigiu os erros nas regras de hierarquia nas sessões aferidas pelo aferidor 2 e os resultados estão apresentados na Tabela 2:

Tabela 2.

Índice de concordância percentual obtido entre a pesquisadora-terapeuta e os aferidores de concordância em cada sessão categorizada pelo FAPRS

Sessões de aferição por fases experimentais

\begin{tabular}{lcccc}
\hline & & A & B & Média \\
\hline Aferidor 1 & $\%$ & $78,81-85,12 *$ & 83,39 & 82,44 \\
\hline Aferidor 2 & $\%$ & 59,70 & 71,32 & 65,51 \\
\hline Aferidor 3 & $\%$ & - & 82,60 & 82,60 \\
\hline
\end{tabular}

*Duas sessões da Fase A foram aferidas por Aferidor 1.

Podemos observar que, diante da correção de tais erros, o aferidor 2 apresentou maior concordância na sessão da Fase B, com 71,32\%, em oposição à sessão não corrigida, com 59,07\%. Porém, na sessão da Fase A, a porcentagem de concordância diminuiu de $67,43 \%$ para $59,70 \%$, e a média aumentou de $63,25 \%$ para $65,51 \%$, conforme mostra a tabela. Estes resultados mostram a necessidade de mudança nos treinos para aferição e na importância de aferidores mais experientes no contato com a FAP e com o instrumento.

O índice do coeficiente Kappa de Cohen, além de produzir o resultado de concordância, também acrescenta a análise das categorizações ao acaso. Para o cálculo desse índice foi utilizado um programa de estatística para pesquisas em ciências sociais (SPSS) da IBM® e os resultados de concordância entre a pesquisadora-terapeuta e ambos os aferidores se encontram dispostos na Tabela 3 abaixo: 


\section{Tabela 3.}

\section{Índice do coeficiente kappa de Cohen obtido entre a pesquisadora-terapeuta e os aferidores de concordância em cada sessão categorizadas pelo FAPRS}

\section{Sessões de aferição por fases experimentais}

\section{A $\quad$ B}

\begin{tabular}{lccc}
\hline Aferidor 1 & Kappa & $0.50-0.51^{*}$ & 0.54 \\
\hline Aferidor 2 & Kappa & 0.39 & 0.40 \\
\hline Aferidor 3 & Kappa & - & 0.52
\end{tabular}

*Duas sessões da Fase A foram aferidas por Aferidor 1.

Conforme apresentado na Tabela 3, foram calculados o índice de coeficiente kappa, no qual foram incluídos na análise todos os turnos categorizados, tanto do terapeuta, quanto do cliente.

Kratochwill et al. (2013) apontam que para atingir os critérios de validade de estudos de caso único o coeficiente kappa deve ser de no mínimo 0.60. Por meio dessa medida psicométrica, conclui-se que nenhum dos aferidores atingiu tal coeficiente. Porém, os aferidores 1 e 3 voltaram a apresentar os melhores resultados, com coeficiente kappa de 0.5 e 0.51 na Fase A para o aferidor 1 , e 0.54 e 0.52 na Fase B para o aferidor 1 e 3, respectivamente.

Em outros estudos, como de Moreira (2018), Vartanian (2017) e Villas-Bôas (2015), foram levantados dados da literatura de dois autores, Landis e Koch (1977), que propuseram uma escala diferente de valores para a interpretação do kappa, divididos em: sem concordância (resultados abaixo de 0), concordância baixa (resultados entre 0 e 0.20 ), concordância razoável (resultados entre 0.21 e 0.40 ), concordância moderada (resultados entre 0.41 e 0,60), concordância substancial (resultados entre 0.61 e 0.80 ) e concordância perfeita (resultados entre 0.81 e 1.00). Partindo-se de tais referências, dos três cálculos 
realizados pelo aferidor 1 , todos encontram-se dentro da concordância moderada. Para o aferidor 2, das duas sessões aferidas, as duas encontram-se dentro da concordância razoável e, no caso do aferidor 3 , a única sessão aferida encontra-se dentro da concordância moderada.

De modo geral, de acordo com os critérios de Kratochwill et al. (2013), por meio do índice de concordância percentual, podemos afirmar que houve concordância entre observadores independentes. Porém, considerando-se o índice do coeficiente kappa de Cohen, não foi possível demonstrar concordância significativa (mínimo de 0.60), mas concordância razoável e moderada, de acordo com as referências de Landis e Koch (1977), como também foi observado em Moreira (2018), Vartanian (2017) e Villas-Bôas (2015). Considerando que o mínimo de concordância exigida é de 20\% (Kratochwill et al., 2013), a significância desse dado torna-se relevante.

Outros pesquisadores que também utilizaram a FAP e o instrumento FAPRS para a categorização das sessões e aferição de concordância entre pesquisador-terapeuta e observadores independentes, obtiveram tanto resultados satisfatórios do coeficiente Kappa, como no caso de (Aranha, 2017; Busch et al., 2009; Mangabeira, 2015; Oshiro, 2011), como resultados abaixo do exigido por Kratochwill et al. (2013), como nos casos de Vartanian (2017) e Villas-Bôas (2015). Da mesma maneira, o índice de concordância percentual foi atingido em Aranha (2017) e Oshiro (2011), e insatisfatório em Lima (2017), Moreira (2018), Vartanian (2017) e Villas-Bôas (2015).

A análise destes resultados revela que a categorização do FAPRS enquanto ferramenta para a aferição de concordância realizada nos estudos sobre a FAP, ainda apresenta limitações importantes. O primeiro fator é devido ao FAPRS ser o único instrumento em que há uma aferição de concordância entre as variáveis dependentes. $\mathrm{Na}$ pesquisa de Moreira (2018), por exemplo, a aferição não foi realizada com os outros 
instrumentos realizados, bem como aconteceu na presente pesquisa. Em segundo lugar, há uma diferença entre considerar as categorias mais representativas da FAP (Regra 2, Regra 3-1, Regra 3-2, CRB1 e CRB2) das menos representativas (TPR, TTR, TO1, TO2, CPR, CTR, O1 e O2) para a aferição, o que não foi possível de analisar na presente pesquisa, devido ao tempo disponível. Além disso, a ausência de sistematização da metodologia de treino de aferidores também contribui para essa limitação, dificultandose uma comparação ente estudos quanto aos resultados de categorizações e das aferições. Como levantado em outros trabalhos, como de Lima (2017), Moreira (2018) e Vartanian (2017), a metodologia de treino para as pesquisas FAP em outros países costuma ser mais sistematizada e extensa, podendo chegar a 100 horas de treino (Busch et al., 2010), diferente do que ocorreu no Brasil, no qual as horas de treino são bem menores, como revelou as pesquisas de Aranha (2017), Lima (2017), Moreira (2018), Villas-Bôas (2015) e Vartanian (2017).

Um outro dado importante, levantado por Vartanian (2017) e que se aplica à presente pesquisa, é acerca da relação entre bons níveis de concordância com os conhecimentos dos aferidores sobre os casos clínicos, mediante a conceituação de caso, e dos treinos destinados à aferição. Ainda assim, muito se discute sobre os vieses de muitas horas de treino para a aferição de concordância, como sinalizou Busch et al. (2010). Na presente pesquisa, demos prioridade a um treino de boa qualidade, mediante uma conceituação de caso detalhada, fornecimento do manual do FAPRS e de uma tabela com as regras para a categorização, além dos aferidores fazerem parte do grupo de pesquisa da pesquisadora-terapeuta, tendo acesso às discussões dos casos clínicos.

Assim, as limitações apontadas no cálculo da aferição de concordância devem ser consideradas nas próximas pesquisas, na tentativa de reduzir vieses e sistematizar um treino de qualidade e de nivelamento para os aferidores escolhidos. 


\section{Resultados e Discussão}

Para a análise dos dados, as sessões foram transcritas, categorizadas, avaliadas quanto à concordância e à tabulação dos dados. A terapeuta-pesquisadora categorizou as sessões de acordo com as categorias do FAPRS, descrito na sessão "instrumentos". Os aferidores de concordância categorizaram, $20 \%$ das sessões, com o objetivo de avaliar o nível de concordância da categorização (Kratochwill, Hitchcock, Horner, Levin, Odom, Rindskopf \& Shadish, 2013). O cálculo de concordância entre as sessões categorizadas é de fundamental importância para aumentar a fidedignidade do trabalho, e foram considerados os valores da concordância bruta e do índice Cohen Kappa, atendo-se a medidas aceitáveis aquelas de concordância acima de $80 \%$ (porcentagem), e acima de 60\% (coeficiente Kappa) (Kratochwill et. al, 2013).

Por meio do instrumento OQ-45, os comportamentos da terapeuta e dos clientes foram categorizados, afim de avaliar a congruência entre as respostas dos clientes. Através da análise dos dados obtidos com os demais instrumentos, BDI, LSAS e SPIN, foram observadas as possíveis mudanças ocorridas com os clientes ao decorrer do processo terapêutico.

Para a avaliação do procedimento (introdução da FAP) foram comparadas a quantidade de CRB's emitidos pelo cliente em cada fase do experimento (Fase A e Fase B). Estas análises permitiram verificar se em algumas das fases houve a produção de maior quantidade de CRB2 e dos sintomas avaliados, e em qual das fases houve diminuição de CRB1 e sintomas avaliados do TAS.

Os dados apresentados a seguir foram obtidos em decorrência da análise de 36 sessões, sendo 11 sessões para os participantes Rodolfo e Murilo, e 15 para o Walter, o qual demandou mais sessões de linha de base para garantir os critérios de estabilidade e tendência dos dados. 
Considerando um total de 24.598 unidades de análises, ou seja, falas da terapeuta (T) e dos clientes (C) emitidas nas 34 sessões de psicoterapia, $8.996(\mathrm{~T}=4.498$ e $\mathrm{C}=$ 4.498) foram nas sessões do participante Rodolfo, 8.862 ( $\mathrm{T}=4.431$ e $\mathrm{C}=4.431)$ do participante Walter e $6.740(\mathrm{~T}=3.370$ e $\mathrm{C}=3.370)$ do participante Murilo. De acordo com o arranjo experimental, de linha de base múltipla, o número total de sessões para os três clientes foi de 34 sessões, com diferenças apenas no momento de mudança de fase para cada um, ou seja, o primeiro completou 10 sessões de linha de base, enquanto os outros dois, Walter e Murilo, 17 e 19 respectivamente.

Os resultados são apresentados respeitando a seguinte ordem: (1) conceituação de casos; (2) dados do M.I.N.I, instrumento de triagem; (3) dados das medidas externas decorrentes do OQ-45, BDI, LSAS e SPIN e, (4) dados obtidos pela Escala de Avaliação da Psicoterapia Analítica Funcional (FAPRS).

\section{(1) Conceituacão de casos}

\section{CLIENTE 1: RODOLFO}

\section{Identificação do cliente}

Rodolfo (nome fictício), 36 anos, solteiro. No início dos atendimentos, o cliente estava desempregado, dedicando-se ao estudo para passar em concursos públicos, já tendo sido chamado em dois concursos (pouco tempo depois, foi chamado em um dos concursos e iniciou o trabalho). Morava com os pais (mãe era do lar e o pai funcionário público) e com a irmã (34 anos, advogada e desempregada). Nunca teve um relacionamento sério e tinha poucos amigos. Já havia feito três anos de terapia, quando tinha 20/21 anos e um ano de acompanhamento psiquiátrico; porém, só recebeu o diagnóstico de ansiedade social aos 26 anos, quando procurou por outros profissionais. 


\section{Queixas apresentadas}

Como queixas iniciais, Rodolfo apresentou dificuldades em criar relacionamentos mais íntimos com as pessoas e em ser assertivo nas diversas interações. Na fase inicial da terapia, o cliente nunca havia tido um relacionamento amoroso e possuía poucos amigos, com os quais não conseguia dividir seus problemas ou pensamentos. Além disso, reclamava bastante sobre dificuldades em dormir, praticar atividades físicas e comer de maneira saudável.

\section{História de vida relevante}

Rodolfo conta que sempre foi um garoto mais "tímido" e que, desde criança, nunca conseguiu fazer muitas amizades. Na escola, teve um excelente desempenho até terminar o colegial, e este era o único aspecto pelo qual sua mãe o valorizava. Segundo os relatos do cliente, a mãe sempre foi uma pessoa bastante controladora, ansiosa e que apenas se relaciona através de brigas. Conta que desde pequeno vive em um ambiente bastante hostil, diante das brigas de sua mãe com o pai e com a irmã. Como sempre foi muito passivo, relata que sempre evitou tais brigas e não confrontava a mãe. O pai, por sua vez, também aparenta problemas em relacionamentos interpessoais, fala pouco e não gosta de sair de casa. Assim, relata não haver um relacionamento entre pais e filhos. Ao longo dos atendimentos, Rodolfo contou ter bastante dificuldade em conseguir fazer as coisas em casa (cozinhar, cuidar de suas roupas, limpeza de seu quarto), pois sua mãe é bastante controladora e não deixava ninguém fazer essas atividades. Assim, tinha dificuldade em iniciar a academia, uma vez que teria de ter uma alimentação mais balanceada e sabia que sua mãe não o deixaria cozinhar. 
Diante de uma criação bastante controladora, Rodolfo relata que sempre se sentiu julgado pelos pais quando tomava alguma decisão e que, por conta disso, sempre tentou fazer coisas "radicais" (como por exemplo, ir a festas rave, usar drogas), que iam contra os pensamentos bastante tradicionais de sua família. Desde pequeno, portanto, lembra de querer sair de casa e pedir para que seus pais se separassem.

Quando tinha aproximadamente 11 (onze) anos, Rodolfo conta que começou a fase das "paqueras", pois se lembra que um primo próximo havia dado o primeiro beijo e, em seguida, sua irmã também. Porém, sempre se sentiu bastante envergonhado e sem saber como agir diante desse tipo de situação e, então, passou a evitar qualquer tipo de assunto ou situação que se relacionasse com o tema. Assim, deu seu primeiro beijo aos 20 (vinte) anos e nunca teve um relacionamento amoroso.

Entrou na faculdade de Arquitetura na USP em 2001 e relata que "levou todo o curso com a barriga" e isso o faz sentir-se bastante culpado. Em termos acadêmicos, havia muitos trabalhos em grupo e isso facilitava um pouco seu desempenho, pois algumas pessoas faziam o trabalho por ele. Porém, quando os trabalhos eram individuais, apresentava bastante dificuldade e não conseguia pedir ajuda aos colegas ou professores. Por não conseguir terminar seu trabalho final de curso, chegou a ser desligado da Universidade, mas pediu para voltar e conseguiu finalizar. No período em que tinha que entregar seu trabalho final, relata ter tido uma crise de ansiedade bastante forte, mais tarde diagnosticada como um ataque de pânico, momento no qual sua mãe o levou a um psiquiatra. Neste período, iniciou uma terapia (a qual perdurou por três anos), juntamente com acompanhamento psiquiátrico. Assim, conseguiu concluir a Universidade.

Mesmo em processo psicoterápico e psiquiátrico, Rodolfo conta que só recebeu o diagnóstico de ansiedade oficial aos 26 anos, três ou quatro anos após o tratamento que iniciou e através de outros profissionais. Ficou bastante aliviado ao ter encontrado uma 
"razão" para como se comportava, porém também bastante desapontado por não ter recebido o diagnóstico mais cedo.

Durante a graduação, chegou a estagiar em duas empresas, mas sempre tinha dificuldades quando tinha de se relacionar com as pessoas. Nas festas da faculdade ou nas rodas de conversa, quando o tema era sobre relacionamentos, dizia sentir um aperto no peito e uma vontade de fugir. Assim, abandonava as situações. As únicas situações em que se sentia bem e motivado eram em festas rave. Diz que sempre gostou muito do tipo de música e significado político-social desse tipo de festa. Quando bebia e/ou usava algumas drogas, conseguia interagir um pouco mais, mas nunca o suficiente para abordar alguma mulher ou fazer novas amizades.

Atualmente, mantém alguns poucos amigos da época da graduação, com quem sai, às vezes, apenas mediante convite. Conta que não consegue convidar as pessoas para sair.

\section{Dificuldades apresentadas/identificação dos comportamentos clinicamente} relevantes

As dificuldades de Rodolfo parecem se concentrar, principalmente, nos relacionamentos interpessoais e assertividade. Quando relata sobre seus relacionamentos, Rodolfo descrevia bastante dificuldade em manter conversas, especialmente quando o assunto era sobre relacionamento amorosos, além de evitar quaisquer conflitos e exposição de opiniões. Assim, quando os temas apareciam, abandonava a conversa. Além disso, apresenta dificuldades em convidar os amigos para sair e expressar seus sentimentos e emoções nas mais diversas interações. 


\section{Comportamentos clinicamente relevantes}

No decorrer da relação terapêutica que se estabelecia, alguns comportamentos emitidos por Rodolfo chamaram a atenção da terapeuta: 1) relatava eventos íntimos e ficava ruborizado, com a voz trêmula, a fala mais sucinta e rápida e o corpo rígido; 2) auto responsabilização excessiva e pedidos de desculpas quando o terapeuta não entendia algum relato; 3) falas se justificando excessivamente e trocas de opinião, concordando com o terapeuta. Tais comportamentos por parte de Rodolfo dificultavam a criação de vínculo com a terapeuta.

Considerando que, fora do ambiente da sessão, o cliente tende a se esquivar de quaisquer conflitos e exposição de opiniões, emitindo comportamentos que visem agradar os outros e evitar uma auto avaliação, ele também emite tais comportamentos dentro da sessão, na relação terapêutica. A seguir, serão descritos alguns CRBs (CRB1 e CRB2), em duas classes (A e B), que correspondem a essas grandes classes de comportamentos, a esquiva de conflitos (A) e intimidade (B), além de informações sobre os possíveis O1s e $\mathrm{O} 2 \mathrm{~s}$, na tentativa de estabelecer os paralelos funcionais entre os comportamentos que ocorrem dentro e fora de sessão, conforme as Tabelas 4 e 5 a seguir: 
Tabela 4.

Comportamentos clinicamente relevantes da classe A de dentro da sessão: do tipo problema (CRB1) e do tipo melhora (CRB2), e comportamentos problema extrassessão (O1) e de melhora extrassessão (O2)

\begin{tabular}{|c|c|c|c|}
\hline O1-A & CRB1-A & $\mathrm{O} 2-\mathrm{A}$ & CRB2-A \\
\hline $\begin{array}{l}\text { Evita qualquer tipo de confronto e } \\
\text { exposição de opiniões; } \\
\text { Topografias: } \\
\text { - Quando a mãe começa a brigar, não } \\
\text { confronta, fica quieto e/ou sai do local; } \\
\text { - Quando alguém discorda dele (família ou } \\
\text { colegas), acata a opinião da pessoa e/ou se } \\
\text { justifica; } \\
\text { - Dificuldade em descrever suas vontades } \\
\text { dentro de casa, especialmente para a mãe; }\end{array}$ & $\begin{array}{l}\text { Esquiva de conflito, caracterizada por } \\
\text { respostas que visam agradar a terapeuta/e } \\
\text { ou concordar com ela, principalmente } \\
\text { diante de assuntos relacionados à família e } \\
\text { relacionamentos interpessoais; } \\
\text { Topografias: } \\
\text { Diante da solicitação de reflexão sobre } \\
\text { algum relato mal compreendido pela } \\
\text { terapeuta: } \\
\text { - Inicia esse tipo de relato com frases do } \\
\text { tipo: "legal, verdade, eu expliquei errado", } \\
\text { "nossa, não deveria ter falado assim, soou } \\
\text { errado", "desculpa, não me expressei } \\
\text { direito"; } \\
\text {-Assume a responsabilidade pelo erro, } \\
\text { justificando-se que não explicou direito e } \\
\text { que por isso o terapeuta não entendeu; ou } \\
\text { troca de opinião, buscando concordar com } \\
\text { a terapeuta; } \\
\text { - Para não desagradar a terapeuta, diante de } \\
\text { ajustes de horários das sessões, diz que a } \\
\text { terapeuta pode marcar nos dias e horários } \\
\text { que forem melhores pra ele e que ele "dá } \\
\text { um jeito", ainda que não possa; } \\
\text {-Ao falar sobre sua família e } \\
\text { relacionamentos, fala de maneira } \\
\text { superficial e rápida, ou muda de assunto e } \\
\text { retorna, após um tempo, para não } \\
\text { desagradar a terapeuta; }\end{array}$ & $\begin{array}{l}\text { Exposição de opiniões e de suas vontades; } \\
\text { Topografias: } \\
\text { - Expor sua opinião sobre algo, mesmo que } \\
\text { diferente das outras pessoas (família e } \\
\text { amigos); } \\
\text { - Expor suas vontades em casa, com seus } \\
\text { pais; }\end{array}$ & $\begin{array}{l}\text { Respostas mais objetivas e descritivas que } \\
\text { demonstrem à terapeuta quando não quiser } \\
\text { falar sobre um assunto, ou que mantenham } \\
\text { sua opinião, mesmo que contrária à da } \\
\text { terapeuta; } \\
\text { Topografias: } \\
\text { Diante da solicitação de reflexão sobre } \\
\text { opiniões contrárias ou sobre família e } \\
\text { relacionamentos: } \\
\text { - Expor suas opiniões, mesmo que } \\
\text { contrárias às da terapeuta, sem justificar-se } \\
\text { ou culpar-se; } \\
\text { - Relatar suas disponibilidades de horários } \\
\text { para as consultas de acordo com seus } \\
\text { compromissos; } \\
\text { - Ao falar sobre sua família e } \\
\text { relacionamentos, falar de maneira mais } \\
\text { descritiva, sem mudar de assunto ou } \\
\text { sinalizar que não quer falar; }\end{array}$ \\
\hline
\end{tabular}


Tabela 5.

Comportamentos clinicamente relevantes da classe B de dentro da sessão: do tipo problema (CRB1) e do tipo melhora (CRB2), e comportamentos problema extrassessão (O1) e de melhora extrassessão (O2)

\begin{tabular}{|c|c|c|c|}
\hline O1-B & CRB1-B & O2-B & CRB2-B \\
\hline $\begin{array}{l}\text { Evita contato com mulheres e assuntos } \\
\text { sobre relacionamentos. } \\
\text { Topografias: } \\
\text { - Quando amigos falam sobre } \\
\text { relacionamentos, se cala ou retira-se } \\
\text { do grupo; } \\
\text { - Dificuldade em aproximar-se quando } \\
\text { tem interesse por alguém ou percebe } \\
\text { que alguma mulher está interessada } \\
\text { nele; } \\
\text { - Apresenta dificuldades em dividir } \\
\text { seus problemas com qualquer pessoa; } \\
\text { - Apresenta dificuldades em pedir } \\
\text { ajuda quando necessita; }\end{array}$ & $\begin{array}{l}\text { Esquiva de intimidade, caracterizada } \\
\text { por comportamentos que evitam } \\
\text { demonstração de vulnerabilidade, } \\
\text { especialmente os que dizem respeito à } \\
\text { sua relação familiar e aos } \\
\text { relacionamentos amorosos; } \\
\text { Topografias: } \\
\text { Diante de solicitação de relato sobre a } \\
\text { relação com seus pais, amigos ou } \\
\text { relacionamento amorosos: } \\
\text { - Fala de maneira concisa e } \\
\text { envergonhada, ou muda de assunto de } \\
\text { maneira sutil e retorna após um tempo; } \\
\text { - Deprecia-se, emitindo uma risada } \\
\text { curta quando conta algo vergonhoso; }\end{array}$ & $\begin{array}{l}\text { Expressar suas opiniões e } \\
\text { sentimentos sobre relacionamentos } \\
\text { de maneira geral; } \\
\text { Topografias: } \\
\text { - Descrever seus incômodos com a } \\
\text { mãe ou amigos quando falam de } \\
\text { assuntos sobre relacionamentos; } \\
\text { - Iniciar conversa com alguém que } \\
\text { lhe interessa e manter o assunto; } \\
\text { - Pedir ajuda diante de alguma } \\
\text { dificuldade ou quando precisar de } \\
\text { algo; }\end{array}$ & $\begin{array}{l}\text { Respostas que expressem como se } \\
\text { sente quando questionado sobre sua } \\
\text { família e relacionamentos; } \\
\text { Topografias: } \\
\text { Diante da solicitação de relato sobre } \\
\text { a relação com seus pais, amigos ou } \\
\text { relacionamentos amorosos: } \\
\text { - Relatar o incômodo que sente ao } \\
\text { falar sobre algum assunto ou apontar } \\
\text { que gostaria de não falar; } \\
\text { - Manter-se no assunto e descrever } \\
\text { como se sente; } \\
\text { - Falas sem auto depreciação diante } \\
\text { da exposição de seus sentimentos, } \\
\text { pensamentos e opiniões; }\end{array}$ \\
\hline
\end{tabular}




\section{Análise Funcional}

De acordo com a análise da história de vida do Rodolfo e de seu comportamento em sessão junto ao terapeuta, pode-se perceber que o maior comprometimento funcional do cliente é na esfera social. Em termos de intimidade e vulnerabilidade, a esquiva de relacionamento interpessoais ocorriam com alta frequência e afastava as pessoas ao seu redor. O medo de julgamento e de avaliação perante os outros faziam com que Rodolfo se comportasse de maneira passiva e não relatasse como se sentia diante das situações, além da tentativa incessante de agradar e ser solícito perante a pedidos, ainda que lhe fosse prejudicar de alguma maneira.

A longo prazo, tais comportamentos tendem a afastar as pessoas do seu convívio, até porque Rodolfo apresentava dificuldades em fazer pedidos e iniciar/manter conversas. Isso resulta em um quadro de isolamento social e solidão.

A cadeia comportamental predominante no repertório do cliente, com base na conceituação de caso até a finalização da pesquisa, se estruturava em duas classes principais: A) diante da solicitação de explicação sobre algum relato não compreendido (antecedente) - o cliente desculpava-se e se responsabilizava pela má explicação e, com isso, evitava possíveis conflitos ou divergências de opiniões $\left(\mathrm{S}^{-}\right)$; e B) diante de conversas sobre relacionamentos íntimos (antecedente), o cliente calava-se ou abandonava a conversa, esquivando-se de expor-se vulnerável e ser julgado por nunca ter tido relações íntimas $\left(\mathrm{S}^{-}\right)$.

A análise dessa cadeia de comportamentos revela um comprometimento na esfera dos relacionamentos interpessoais, dado que a exposição à pessoas coloca o ansioso social em situação de intimidade e vulnerabilidade. Dessa forma, como resposta comum, a esquiva de conflitos e de intimidade é reforçada pela retirada de um possível estímulo aversivo. Essa cadeia de comportamentos se mantém e se repete, continuadamente no 
decorrer da história de vida do ansioso social, ocasionando grandes déficits de habilidades sociais, reforçando o comportamento de não exposição do indivíduo.

\section{CLIENTE 2: WALTER}

\section{Identificação do cliente}

Walter (nome fictício), 22 anos, solteiro. No início dos atendimentos, o cliente estava estudando, em casa, para o vestibular de medicina. Dos últimos seis anos, quatro o cliente estudou no cursinho (com bolsa integral), e os outros dois em casa. Chegou a passar no curso em três universidades públicas, mas alegava não ter condições financeiras e psicológicas de se mudar da cidade, além de ter o sonho de cursar na USP de São Paulo. Morava com os pais (mãe era do lar e o pai padeiro) e com dois irmãos. Nunca teve um relacionamento sério e tinha poucos amigos. Desde os 15 anos passava por psiquiatras (num posto de saúde na região onde mora) e, desde então, tomava medicação. Em 2016 deu início a um tratamento no IPq, mas nunca passou por terapia. Recebeu o diagnóstico de ansiedade generalizada, primeiramente, e, após alguns anos, de ansiedade social. Ao final dos atendimentos, Walter conseguiu ingressar em Medicina na Universidade de São Paulo.

\section{Queixas apresentadas}

Como queixas iniciais, Walter apresentou bastante dificuldades em lidar com críticas, avaliações e julgamentos, especialmente em relação à situação de estar estudando há anos e ainda não ter entrado em uma universidade. Dizia que tinha medo de se sentir burro, das pessoas rirem dele. Por outro lado, apresentava dificuldades em criar relacionamento íntimos com as pessoas. Na fase inicial dos atendimentos, o cliente nunca havia tido um relacionamento amoroso e possuía poucos amigos, com os quais dizia 
conseguir se expressar e falar de seus problemas. Além disso, apresentava dificuldades para dormir e trocava o dia pela noite. No decorrer dos atendimentos, apresentou um incômodo com a questão de chorar, alegando que não consegue chorar e acredita que, se conseguisse, isso iria aliviar suas angústias.

\section{História de vida relevante}

Walter relatava sempre ter sido um garoto mais tímido. Quando pequeno, vivenciava cena de brigas e agressões entre os pais. Dos 6 aos 9 anos de idade, contou que seu pai bebia muito e era muito estressado em relação ao trabalho. Assim, neste período, ao menos uma vez por semana, o pai chegava em casa e agredia a mãe. Chegou a ir em delegacias junto da mãe, algumas vezes, para denunciar as agressões. Ao relatar esta história, Walter disse que era a primeira vez que contava para alguém sobre as agressões familiares e que acredita que isso contribuiu para o desenvolvimento de ansiedade. $\mathrm{O}$ cliente relatou que os pais resolveram esta situação sem conversar sobre o assunto e que não se falava sobre isso dentro de casa. Alguns vizinhos eram seus parentes e sabiam do ocorrido, e Walter afirmava ter muita vergonha. Além disso, afirmava não ter uma boa relação com vários parentes, por um descompasso entre gerações, valores, e opiniões de alguns tios sobre o fato dele apenas estudar (tios diziam que ele "só estudava e que não estava dando certo"). Apesar disso, afirmava que sempre teve uma relação familiar "bem honesta, bem desconstruída" e que o pai sempre foi "um excelente pai, mas um péssimo marido".

Desde pequeno sempre gostou muito de ler. Por conta das idas de sua irmã ao hospital, semanalmente, Walter começou a gostar do ambiente médico e a se interessar por livros de anatomia e biologia. Contava que aprendeu a ler com quatro anos e sempre foi bastante questionador, se intrometia na conversa dos mais velhos, e que, muitas vezes, 
familiares e primos diziam que ele era muito arrogante, intrometido e que fazia muitas perguntas.

Contando sobre sua relação familiar presente (na época dos inícios dos atendimentos), Walter dizia se sentir amado, apesar da mãe fazer comentários sobre sua aparência desde pequeno (como por exemplo, "sua boca é muito grande", "sua cabeça é muito grande", "você é muito feio", "sua barba é errada e seu cabelo é estranho"). Falava que sabia que a mãe estava brincando, mas que esses comentários o machucavam um pouco. Apesar disso, o cliente dizia que precisava ser honesto e que não se sentia um bom filho, uma vez que, devido ao seu comportamento irritadiço, brigava muito com os pais e os xingava, sentindo-se culpado e envergonhado. Também revidava os comentários da mãe, dizendo que ela estava "gorda".

Walter percebeu que alguns sintomas de ansiedade começaram a surgir na passagem do ensino fundamental para o ensino médio, nas primeiras semanas de aula de cada semestre, com os novos professores e disciplinas. Os sintomas eram fisiológicos (dor de barriga, vômitos, formigamentos nas mãos e braços), especialmente na hora de dormir e horas antes do início das aulas. Nos episódios de mal-estar, ia ao pronto socorro e era diagnosticado com virose. Com o passar do tempo, os médicos começaram a indicar que Walter procurasse um psiquiatra. Assim o fez e, a partir dos 15 anos, começou a tomar antidepressivo. Os comportamentos ansiosos começaram, então, a aparecer em outras situações, tais como sair para comprar roupa, receber crítica de professores, falar em seminários. O cliente continuava com o psiquiatra, porém não sentia efeito na medicação e tinha dificuldades em relatar ao médico que o remédio não estava fazendo efeito.

Em 2016, através de um e-mail do IPq, começou a participar de um grupo de apoio, mas contou não sentir efeitos de melhora, além de sentir mais ansiedade ao ouvir as crises das outras pessoas. Porém, considerando que não sentia que estava piorando, 
continuava nas atividades. No segundo semestre do mesmo ano, ainda na pesquisa, recebeu uma abordagem mais diretiva, com atividades semanais propostas por um psiquiatra-terapeuta. Foi então que conseguiu contar a este profissional que a medicação da qual fazia uso não estava fazendo efeito. Assim, lhe foi recomendado o uso de quetiapina (60 mg), medicação da qual fazia uso até o momento. Com a nova medicação, percebeu que os sintomas ansiosos diminuíram (por exemplo, não teria conseguido comparecer na primeira sessão se não tivesse usando medicação, pois disse que passaria mal, com vontade de vomitar, e se preocuparia em excesso com o julgamento da psicóloga). Com as atividades diretivas que recebia no IPq, contou que aprendeu a "perceber" que as pessoas não estavam necessariamente o julgando, e que eram apenas seus pensamentos. Porém, sem medicação, não conseguia seguir esta linha de raciocínio. Até o momento do início dos atendimentos, continuava com o psiquiatra, mas o tratamento do IPq estava encerrado.

Walter contou ter o sonho de passar em medicina na USP de São Paulo, e que se trata de uma "questão narcísica". Já foi aprovado em algumas universidades públicas renomadas. Por ter condições financeiras restritas, após a primeira aprovação, foi até um cursinho em São Paulo levando o comprovante de aprovação em medicina e pediu uma bolsa integral de estudos. Com isso, teve bolsa por quatro anos. Contou que o ambiente no cursinho era péssimo para a saúde mental, estimulando a competição acirrada entre os estudantes. Assim, nos últimos dois anos, estudou por conta própria em casa. Quando questionado pela terapeuta o porquê de querer fazer medicina, o cliente disse que se tratava de algo "muito subjetivo, tendo adquirido consciência política e social, decidiu emprestar essa consciência para a medicina e fazer desse desejo pela medicina algo mais bonito". É importante ressaltar que o cliente apresenta uma fala bastante rebuscada, em todo seu discurso. 
Ao ser questionado sobre sua rotina no momento, Walter contou que sua vida social era bastante reclusa, especialmente em função dos estudos. Apresentava dificuldades em fazer amizades por ser bastante tímido e introspectivo. Não gostava de ir em festas, dizia "reconhecer o seu direito em não ir, mas não gostava. Eram jovens com valores nem piores e nem melhores, tão válidos quanto os dele, mas não se encaixava neste perfill”. Além disso, não se sentia confortável com sua imagem, achando-se muito feio, "mais do que o normal", e com uma autoestima muito baixa.

Os poucos amigos que tinha eram da época do cursinho. Com eles conseguia falar sobre tudo, inclusive sobre sua sexualidade (bissexual). Em casa, contou que os pais não sabiam, pois eram conservadores. Sobre os amigos, dizia que sabiam que ele era "bi, de esquerda, progressistas e que não defendia os valores tradicionais da família brasileira”.

Quando passou nos vestibulares, relatou ter se sentido bem e que a aprovação mais bonita foi quando estudou sozinho, uma vez que se sentiu recompensado. Contou que os pais se orgulhavam de ter um filho que foi aprovado em medicina e que, às vezes, falavam isso para as pessoas. Porém, não sentiu que foi o dia mais feliz de sua vida, como contam os amigos que foram aprovados. Walter disse que, para além do sonho de estudar em São Paulo, não tinha condições financeiras de mudar de cidade e não se sentia psicologicamente forte para viver tal experiência no momento.

Com as sucessivas reprovações no vestibular da USP São Paulo, se preocupava cada vez mais com o que as pessoas iriam pensar sobre ele, sentindo uma sensação de derrota constante. No momento inicial dos atendimentos, contou ter a sensação de estar estagnado, devido a tais reprovações.

Nunca havia beijado e considerava a questão de sua sexualidade uma variável importante nesta situação. Se achava muito feio, mais do que o normal, não se sentindo 
confortável para paquerar. Se apaixonou uma vez, por cinco anos, e não conseguiu contar para a pessoa. No final de 2017, se apaixonou novamente, conseguiu dizer para a pessoa, mas não foi correspondido, e isto o machucou bastante.

Como lazer, dizia que gostava de ler livros, de passear em parques e até de ficar quieto e pensando na vida.

\section{Dificuldades apresentadas/identificação dos comportamentos clinicamente relevantes}

As dificuldades de Walter pareciam se concentrar, especialmente, no campo das relações interpessoais, com um medo intenso de ser julgado e avaliado como incapaz e não inteligente, além de ter uma autoimagem bastante depreciativa a respeito de si mesmo, fazendo com que se aproximasse pouco das pessoas. Quando relatava sobre seus relacionamentos com as outras pessoas, descrevia dificuldades em receber críticas (como por exemplo, que ele estava estudando muito e, mesmo assim, não entrava na faculdade; ou que não adiantava passar nos vestibulares e não se matricular). Quando tais críticas e avaliações apareciam, ficava muito triste, sem sair do quarto, sentindo-se culpado e perdedor. Além disso, apresenta dificuldades em expressar-se quando as pessoas fazem comentários que o magoam.

\section{Comportamentos clinicamente relevantes}

No decorrer do início da relação terapêutica, alguns comportamentos de Walter chamaram a atenção da terapeuta: 1) apresentava um repertório verbal bastante rebuscado e verborrágico, quando a terapeuta solicitava relatos ou descrições de eventos ou sensações e, muitas vezes, parecia responder perguntas específicas com frases decoradas; 
2) dificuldades em expressar sentimentos e aproximar-se da terapeuta; 3) solicitava ou responsabilizava o terapeuta por decisões que deveriam ser tomadas.

Considerando que, fora do ambiente da sessão, o cliente tende a se esquivar de engajar-se em relacionamentos, emitindo comportamentos que visem agradar os outros, e evitar uma auto-avaliação, ele também emite tais comportamentos dentro da sessão, na relação terapêutica. A seguir, serão descritos alguns CRBs (CRB1 e CRB2) que correspondem a essas grandes classes de comportamentos, a esquiva relacionamentos que sinalizem vulnerabilidade e intimidade, além de informações sobre os possíveis O1s e $\mathrm{O} 2 \mathrm{~s}$, na tentativa de estabelecer os paralelos funcionais entre os comportamentos que ocorrem dentro e fora de sessão, conforme as Tabelas 6 e 7 a seguir. 
Tabela 6.

Comportamentos clinicamente relevantes da classe A de dentro da sessão: do tipo problema (CRB1) e do tipo melhora (CRB2), e comportamentos problema extrassessão (O1) e de melhora extrassessão (O2)

\begin{tabular}{|c|c|c|c|}
\hline O1-A & CRB1-A & O2-A & CRB2-A \\
\hline $\begin{array}{l}\text { Evita falar sobre seus sentimentos e } \\
\text { expressar opiniões com familiares e } \\
\text { amigos; } \\
\text { Topografias: } \\
\text { - Mantém diálogos com falas rebuscadas, } \\
\text { com família e amigos, e conta que já } \\
\text { recebeu rótulo de arrogante por este } \\
\text { motivo; } \\
\text { - Evita falar sobre os estudos e vestibular, } \\
\text { com medo de ser julgado por ainda não } \\
\text { ter entrado na universidade; } \\
\text { - Valoriza muito o repertório intelectual, } \\
\text { depreciando comportamentos } \\
\text { autocuidado (cortar o cabelo, comprar } \\
\text { uma roupa, assistir um programa para } \\
\text { distração, etc). Exemplo: "prefiro ser } \\
\text { rotulado como inteligente e feio, do que } \\
\text { como bonito e burro" } \\
\text { - Diante de comentários desagradáveis, } \\
\text { feitos pela mãe, sobre sua aparência, } \\
\text { cala-se e não relata como se sente; }\end{array}$ & $\begin{array}{l}\text { Esquiva de intimidade, caracterizada por um } \\
\text { relato verborrágico e rebuscado, evitando } \\
\text { comportamentos que indiquem vulnerabilidade } \\
\text { e julgamentos/avaliações, especialmente sobre } \\
\text { sua inteligência; } \\
\text { Topografias: } \\
\text { Diante da solicitação de relato sobre como se } \\
\text { sente com o vestibular e em sua relação com a } \\
\text { família: } \\
\text { - Falas bastante refinadas e, aparentemente, } \\
\text { decoradas, como por exemplo: "minha escolha } \\
\text { por medicina é muito subjetiva, eu adquiri } \\
\text { consciência política e social, e decidi emprestar } \\
\text { essa consciência para a medicina e fazer desse } \\
\text { desejo pela medicina algo mais bonito"; ou "sou } \\
\text { bi, de esquerda, progressista e que não defendia } \\
\text { os valores tradicionais da família brasileira". } \\
\text { - Invalida o que sente, falando sobre } \\
\text { sentimentos bons e ruins sem expressar } \\
\text { diferença, como por exemplo, quando conta que } \\
\text { sua mãe o xinga ou faz algum comentário } \\
\text { depreciativo sobre sua aparência e diz estar } \\
\text { acostumado e não ligar; } \\
\text { - Solicita e responsabiliza o terapeuta por suas } \\
\text { decisões ou melhora, por exemplo: pediu para } \\
\text { que a terapeuta explicasse a terapia para ver se } \\
\text { valeria a pena continuar em São Paulo, ao invés } \\
\text { de ingressar na universidade; }\end{array}$ & $\begin{array}{l}\text { Relatar de maneira mais simples e } \\
\text { descritiva seus sentimentos e } \\
\text { pensamentos nas relações; } \\
\text { Topografias: } \\
\text { - Nas conversas com família e } \\
\text { amigos/colegas, falar de maneira mais } \\
\text { simples, de modo a aproximá-los; } \\
\text { - Sinalizar que se sentiu } \\
\text { desconfortável quando pais ou amigos } \\
\text { fizerem algum comentário que o } \\
\text { machuque; de conversas sobre } \\
\text { - Diante de } \\
\text { vestibular, sinalizar que não quer falar } \\
\text { sobre ou descrever sua experiência, } \\
\text { validando-a. }\end{array}$ & $\begin{array}{l}\text { Relato verbal mais simples e } \\
\text { descritivo, que sinalizem maior } \\
\text { aproximação e intimidade nas } \\
\text { relações; } \\
\text { Topografias: } \\
\text { Diante da solicitação de relato sobre o } \\
\text { que sente, a situação do vestibular e } \\
\text { suas relações interpessoais: } \\
\text { - Respostas mais simples e } \\
\text { descritivas; sentimentos, expressando } \\
\text { - Validar sand } \\
\text { quando sentir tristeza, raiva, } \\
\text { felicidade etc; suas } \\
\text { - Responsabilizar-se sobre suas } \\
\text { decisões e discriminar suas } \\
\text { dificuldades, avaliando o que é } \\
\text { melhor para si no momento; }\end{array}$ \\
\hline
\end{tabular}


Tabela 7.

Comportamentos clinicamente relevantes da classe B de dentro da sessão: do tipo problema (CRB1) e do tipo melhora (CRB2), e comportamentos problema extrassessão (O1) e de melhora extrassessão (O2)

\begin{tabular}{|c|c|c|c|}
\hline O1-B & CRB1-B & O2-B & CRB2-B \\
\hline $\begin{array}{l}\text { Rotula seus próprios } \\
\text { comportamentos e de amigos e } \\
\text { familiares entre fúteis e } \\
\text { intelectuais; } \\
\text { Topografias: } \\
\text { - Quando a mãe troca a foto do } \\
\text { WhatsApp com frequência, fica } \\
\text { irritado e acha fútil alguém se } \\
\text { importar com isso; } \\
\text { - Quando a mãe pede opinião } \\
\text { sobre a roupa dela, ele diz que } \\
\text { não importa e que acha brega, e } \\
\text { reclama dela perguntar esse tipo } \\
\text { de coisa; } \\
\text { - Perde a vontade de manter uma } \\
\text { conversa quando percebe que a } \\
\text { pessoa não tem o mesmo } \\
\text { conhecimento que ele sobre } \\
\text { determinado assunto } \\
\text { (especialmente sobre política, } \\
\text { sociedade, etc); }\end{array}$ & $\begin{array}{l}\text { Rotula de maneira dicotômica (intelectual } \\
\text { X fútil) comportamentos que expressem } \\
\text { preocupação com autocuidado, aparência } \\
\text { física, universidades, invalidando seus } \\
\text { sentimentos e afastando o terapeuta; } \\
\text { Topografias: } \\
\text { Diante de questionamento sobre aparência } \\
\text { física e atividades de laser: } \\
\text { - Classifica tais questões como fúteis, como } \\
\text { por exemplo: "tem coisas mais importantes } \\
\text { do que cortar o cabelo", "preciso comprar } \\
\text { mais roupas, mas já gastei tudo com livros, } \\
\text { porque acho mais importante"; "meu } \\
\text { queixo é feio, me incomoda, mas vou } \\
\text { deixar a barba por uma questão política, } \\
\text { sabe?", } \\
\text { - Quando o terapeuta sugere atividades para } \\
\text { o bem-estar, o cliente diz que se sente } \\
\text { perdendo tempo se assistir outras coisas } \\
\text { que não o enriqueça intelectualmente; } \\
\text { - Rotula a terapia comportamental como } \\
\text { mais diretiva e protocolar do que a } \\
\text { psicanálise, dizendo que esta poderia trazer } \\
\text { mais entendimento sobre quem ele é e suas } \\
\text { questões; }\end{array}$ & $\begin{array}{l}\begin{array}{l}\text { Expressar sua opinião à mãe ou } \\
\text { amigos, } \\
\text { comportamentos; } \\
\text { rotular }\end{array} \\
\text { Topografias: } \\
\text { - Manter uma conversa mesmo se } \\
\text { perceber que possui mais } \\
\text { conhecimento sobre o assunto do que } \\
\text { a outra pessoa; } \\
\text { - Investir em comportamentos de } \\
\text { autocuidado: cortar o cabelo, aparar } \\
\text { a barba, comprar roupas novas (todas } \\
\text { ações que julgava como fúteis, mas } \\
\text { que sabia que diziam respeito ao } \\
\text { autocuidado); }\end{array}$ & $\begin{array}{l}\text { Validar sentimentos e ações acerca } \\
\text { de questões sobre sua aparência, } \\
\text { gostos, hobbies, escolhas de } \\
\text { trabalho, etc; } \\
\text { Topografias: } \\
\text { Diante de solicitação de relato sobre } \\
\text { aparência, autocuidado, hobbies, } \\
\text { trabalho: diminuindo o } \\
\text { - Validar seus sentimentos diante de } \\
\text { tais questões, dimatas para } \\
\text { comportamento de rotulá-las } \\
\text { explicá-las; }\end{array}$ \\
\hline
\end{tabular}




\section{Análise Funcional}

De acordo com a análise da história de vida de Walter e de seu comportamento em sessão junto ao terapeuta, pode-se perceber que o maior comprometimento funcional do cliente é na esfera social. Em termos de intimidade e vulnerabilidade, a esquiva de relacionamento interpessoais ocorriam com alta frequência e afastava as pessoas ao seu redor. O medo de julgamento e de avaliação perante os outros faziam com que Walter se comportasse de maneira, muitas vezes, julgada como "arrogante", devido ao seu repertório verbal bastante rebuscado, e passivamente, ao não relatar como se sentia diante de comentários depreciativos quanto sua aparência.

A longo prazo, tais comportamentos tendem a afastar as pessoas do seu convívio, até porque Walter apresentava dificuldades iniciar/manter conversas e expressar-se de maneira assertiva. Isso resulta em um quadro de isolamento social e solidão.

A cadeia comportamental predominante no repertório do cliente, com base nas primeiras sessões de conceituação do caso, se estruturava da seguinte maneira: diante de perguntas/conclusões de outras pessoas sobre sua vida pessoal e estudos (antecedente) o cliente verbaliza de maneira bastante rebuscada, com o intuito de destacar seu conhecimento intelectual e esquivar-se de entrar em contato com seus sentimentos e vulnerabilidades e, com isso, as pessoas ao redor se afastam e o chamam de "arrogante" $\left(\mathrm{S}^{-}\right)$. Após o início da Fase B, com a introdução da VI (FAP) e manejo dos CRB1s - A, um novo CRB1 apareceu (CRB1-B), dentro da mesma classe de esquiva de intimidade. O cliente passou a emitir um relato bastante dicotômico sobre situações e comportamentos que levantávamos como importantes de modificar: aparência física, autocuidado, vida profissional, faculdade, sempre rotulando entre "intelectual" e "fútil". Tudo o que não estivesse na esfera do intelectual, Walter classificava como fútil, gerando 
um afastamento do terapeuta e das pessoas ao seu redor, e esquivando-se de comportamentos de autocuidado, que alimentavam a sua autoestima.

Considerando os déficits comportamentais que a literatura apresenta para pessoas com ansiedade social, podemos perceber de maneira clara um comprometimento na esfera dos relacionamentos interpessoais, uma vez que a exposição às pessoas ocasiona vulnerabilidade e esquiva da possibilidade de um evento ansiógeno (julgamentos e avaliações negativas). Com isso, a esquiva de relacionamentos que sinalizem intimidade e vulnerabilidade é reforçada pela retirada de um possível estímulo aversivo. Esse repertório de comportamento se repete, continuamente, ao longo da vida do ansioso social, promovendo um déficit de habilidades sociais e evitando que a pessoa se exponha.

\section{CLIENTE 3: MURILO}

\section{Identificação do cliente}

Murilo (nome fictício), 20 anos, solteiro. No início dos atendimentos, o cliente já havia terminado o ensino médio, há dois anos, e, desde então, não estudava ou trabalhava. Chegou a trabalhar em um banco como atendente, onde trabalhou por três meses, e saiu por conta de suas dificuldades de se relacionar. Morava com os pais e dois irmãos (um mais velho e um mais novo). Seu irmão mais velho trabalhava em uma feira, e o mais novo ainda estava na escola. Os três dividiam o mesmo quarto, motivo de algumas desavenças. Até o momento, havia tido um relacionamento de três meses com uma garota, o qual terminou poucos meses antes do início do processo terapêutico. Murilo relatou que o término desse relacionamento lhe causou muito sofrimento e que, após o evento, não conseguia mais trabalhar, sair de casa ou pensar em se relacionar novamente. Até o momento, nunca havia passado por um psicólogo ou psiquiatra. 


\section{Queixas apresentadas}

Como queixas iniciais, Murilo relatou muitas dificuldades em criar relações interpessoais, desde iniciar um primeiro contato, até conversar e manter conversas, relatando muito receio de ser criticado, avaliado ou julgado por não conseguir falar e ser quieto. Dizia que sempre foi muito brincalhão, gostando de contar piadas e de brincadeiras lúdicas, e achava que as pessoas não o levavam à sério ou o julgavam como criança. Seu jeito desajeitado, sempre tropeçando em tudo, também o incomodava e sentia que era foco de avaliação. Por não estar estudando e trabalhando, sentia-se culpado e pressionado a ajudar em casa, já que sua mãe também não trabalhava e seu pai e irmão mantinham o sustento financeiro da casa. Tinha um melhor amigo, desde a infância, chamado Diogo (nome fictício), com quem tinha contato diariamente, muitas horas por dia, e praticamente a única referência de relacionamento interpessoal na época, com quem conseguia falar sobre quase tudo.

\section{História de vida relevante}

Murilo relatou ter sido uma criança mais tímida e "diferente", pois era mais sensível, gostava de brincadeiras artísticas, contar piadas e "viver no mundo da lua". Desde cedo, notava que esses comportamentos não eram muito valorizados em casa ou por amigos, sendo sempre punido, recebendo chacotas e xingos dos irmãos e pai. Desde cedo, relatou que em sua casa haviam sempre muitas regras, desde como falar, como comportar-se, o que fazer e como ser; portanto, sentia-se muito vigiado todo o tempo, junto de seus irmãos. Quando desobedeciam as regras, ficavam de castigo e, às vezes, apanhavam. Murilo contou de um episódio que marcou em que brincava na rua com seus amigos, e seu pai foi chamar sua atenção. Sem pensar, respondeu ao que o pai dizia e o pai o bateu na frente dos amigos, até ele "fazer xixi nas calças". 
$\mathrm{Na}$ escola, sempre foi muito quieto e tinha poucos amigos, mas com o tempo foi se sentindo deslocado, como se não fizesse parte de nenhum grupo e sentia que as pessoas se afastavam dele. Esta sensação perdurou até o ensino médio, momento em que sentia que as pessoas o olhavam de maneira diferente e se afastavam, como se ele tivesse "uma energia ruim". Ao terminar o colégio, não teve oportunidade de ingressar em uma universidade, mas fez um curso gratuito de desenho por um ano. Junto do amigo Diogo, faz animações e, em conjunto, criaram uma animação que ganhou um concurso, durante o processo terapêutico. Além de desenhar, Murilo gostava muito de ler e ficar cuidar do seu primo mais novo. Ele o melhor amigo, Diogo, faziam uso de maconha diariamente.

Murilo relatou que sentia uma angústia muito forte no peito, bastante desânimo e não sabia mais o que fazer para mudar. Ao mesmo tempo que dizia que sabia que não era uma escolha se sentir assim, culpava-se muito. Ainda, seu pai dizia que isso era preguiça e falta de trabalho, e sua mãe o defendia mais. Sua mãe teve síndrome do pânico por muitos anos, e desde cedo conversava com o filho sobre isso. Os dois são mais próximos um dos outros do que os outros irmãos. Por ter tido síndrome do pânico, Murilo dizia que sentia que sua mãe o compreendia melhor, e sabia que ele não tinha culpa de sentir o que sentia. Como sentiam coisas muito parecidas, Murilo e sua mãe acabaram concluindo que ele também sofria de ansiedade e, lendo na internet sobre o assunto, encaixou-se no perfil de um ansioso social.

Ele e seus irmão não tinham uma relação muito próxima, não conversando muito. O irmão mais velho, por trabalhar e namorar, não ficava muito tempo em casa e, o mais novo, ainda na escola, também ficava mais na rua. Dividiam o mesmo quarto, o que acabava sendo fonte de algumas brigas por desorganização, por barulhos e personalidades diferentes. Murilo contou que chegaram a ter algumas brigas fortes, na qual um dos irmãos partiu pra cima dele dizendo que ia lhe matar. Outras vezes, Murilo descontrolou- 
se e sentiu uma vontade grande de bater no irmão, mas foi impedido por outro. Neste sentido, contava que sentia muito mal por ter se descontrolado algumas vezes e tinha medo que pudesse perder o controle e machucar alguém.

Ao final do processo psicoterapêutico, Murilo teve três crises fortes de ansiedade, tendo sido levado ao hospital. Algumas das últimas sessões foram destinadas a acolher o cliente e manejar a ansiedade. Murilo conseguiu, aos poucos, aceitar as sensações, praticar alguns exercícios ensinados em terapia e controlar a ansiedade diante de novos episódios. Além disso, foi ao psiquiatra, iniciou o uso de medicamento para a ansiedade e pra o sono e cessou o uso de maconha. A questão do sono era um problema bastante relatado. Por dormir muito tarde (ficava na casa do Diogo desenhando, conversando e fumando), acordava muito tarde e, em dias da sessão da terapia, que aconteciam no período da manhã, sentia-se muito cansado. Quando acordava cedo, sentia-se mais alegre, portanto, organizar os horários de sono o ajudaram em sua motivação.

\section{Dificuldades apresentadas/identificação dos comportamentos clinicamente relevantes}

As dificuldades de Murilo pareciam se concentrar, especialmente, no campo das relações interpessoais, com muito medo de ser avaliado e julgado de maneira negativa ou por sua autoimagem "estranha". Murilo apresentava muita dificuldade em conseguir descrever seus sentimentos e pensamentos, se autojulgando de maneira excessiva. Tal comportamento fazia com que o cliente, antes de aproximar-se de alguém, se julgasse a tal ponto de já concluir não ser bom o suficiente para qualquer interação. Quando relatava sobre seus relacionamentos com as outras pessoas, descrevia dificuldades em aproximarse e cumprimentar, iniciar ou manter assuntos. Assim, geralmente ficava quieto e de cabeça baixa. Poucas foram as vezes em que Murilo conseguiu lembrar-se de eventos em 
que alguém o julgou ou o avaliou, mas algumas vezes aconteceram, quando um grupo de meninos da rua julgaram ele e Diogo como pessoas "estranhas e sem noção" e se afastaram. Além disso, Murilo relatou que sentia ter uma "energia negativa" e percebia que as pessoas o olhavam de maneira estranha. Por conta da ansiedade, Murilo tinha muita dificuldade de fazer contato visual, enquanto andava ou falava com pessoas (inclusive com a terapeuta no início do processo), tinha uma postura curva e retraída, mexia muito nas mãos e na cabeça enquanto falava. Devido à sua dificuldade em descrever quem ele era, suas sensações, sentimentos e pensamentos, no início do processo terapêutico, quanto questionado pela terapeuta sobre um desses aspectos, Murilo explicava com uma linguagem lúdica e artística, utilizando-se de exemplos e metáforas. Ainda, era sempre muito gentil e procurava agradar muito a terapeuta.

\section{Comportamentos clinicamente relevantes (CRBs)}

No decorrer do início da relação terapêutica, alguns comportamentos de Murilo chamaram a atenção da terapeuta: 1) apresentava bastante dificuldade em descrever o que sentia ou pensava, especialmente sobre si mesmo e, nestas situações, emitia respostas físicas típicas da ansiedade, como não olhar nos olhos, mexer muito nas mãos e cabelo, balançar as pernas, curvar-se na cadeira, gaguejar, etc; 2) excesso de julgamento e depreciação acerca de si mesmo, em detrimento da idealização dos outros; 3) dificuldade em aproximar-se do terapeuta. Tais comportamentos por parte de Murilo dificultavam a criação de vínculo com o terapeuta.

Considerando que, fora do ambiente de sessão, o cliente tende a se esquivar de quaisquer situações nas quais tenha que criar um contato ou conversar com alguém, ficando recluso ou bastante quieto, ele também emite tais comportamentos dentro da sessão, na relação terapêutica. A seguir, serão descritos alguns CRBs (CRB1 e CRB2), 
em uma única classe, que corresponde a esses comportamentos, a esquiva de intimidade, além de informações sobre os possíveis O1s e O2s, na tentativa de estabelecer os paralelos funcionais entre os comportamentos que ocorrem dentro e fora de sessão, conforme Tabela 8 a seguir: 
Tabela 8.

Comportamentos clinicamente relevantes de dentro da sessão: do tipo problema (CRB1) e do tipo melhora (CRB2), e comportamentos problema extrassessão (O1) e de melhora extrassessão (O2)

\begin{tabular}{|c|c|c|c|}
\hline $\mathrm{O} 1$ & CRB1 & $\mathrm{O} 2$ & CRB2 \\
\hline $\begin{array}{l}\text { Evita exposição/contato com } \\
\text { pessoas, devido a uma pré- } \\
\text { avaliação negativa } \\
\text { (autojulgamentos e depreciação) } \\
\text { sobre si mesmo: } \\
\text { - Fica em casa a maior parte do } \\
\text { tempo; } \\
\text { - Quando encontra pessoas, fica } \\
\text { quieto, de cabeça baixa, com um } \\
\text { comportamento embotado, pois } \\
\text { acha que qualquer coisa que ele fale } \\
\text { ou faça será ruim; } \\
\text { - Quando se relaciona com o melhor } \\
\text { amigo, a depender do assunto (algo } \\
\text { que ele não sabe/conhece), fala } \\
\text { pouco; } \\
\text { - Quando reage ao que sente } \\
\text { (raiva/felicidade) diante do outro, } \\
\text { emite respostas desproporcionais, } \\
\text { como por exemplo: brigou com a } \\
\text { mãe do melhor amigo, por ela não } \\
\text { reconhecer o quanto o filho é bom; } \\
\text { ele e o amigo ganharam um prêmio } \\
\text { de um curta que fizeram e se } \\
\text { esconderam do público, pois } \\
\text { estavam muito eufóricos; }\end{array}$ & $\begin{array}{l}\text { Esquiva de intimidade, quando solicitado } \\
\text { relato sobre si mesmo (o que sente/pensa), } \\
\text { emite respostas pouco descritivas e bastante } \\
\text { genéricas ou metafóricas, gerando um } \\
\text { afastamento da terapeuta; } \\
\text { Topografias: } \\
\text { Diante de solicitação de descrição sobre } \\
\text { como se sente/pensa: } \\
\text { - Emite respostas genéricas que demonstram } \\
\text { pouco autoconhecimento, por exemplo: } \\
\text { quando questionado sobre como se sente em } \\
\text { casa, Murilo diz: "não sei", "fico no meu } \\
\text { quarto", "é chato", ou faz associações com } \\
\text { conteúdo de desenhos ou arte, como } \\
\text { exemplo: "é como se o mundo acabasse e eu } \\
\text { estivesse sozinho", "igual } \\
\text { personagem", "sozinho como a escuridão da } \\
\text { noite", etc; } \\
\text { - Respostas de autojulgamento e avaliações } \\
\text { excessivas a respeito de si mesmo, sempre } \\
\text { idealizando muito o outro e se depreciando; } \\
\text { - Diante de perguntas sobre si mesmo, reage } \\
\text { fisicamente de maneira "esquisita", como ele } \\
\text { mesmo classifica: se curva, mexe muito nas } \\
\text { mãos, entorta as pernas, olha para baixo, } \\
\text { treme as mãos e a voz; }\end{array}$ & $\begin{array}{l}\text { Descrever como se sente e o que } \\
\text { pensa para pessoas com quem se } \\
\text { sinta mais seguro: } \\
\text { - Aproximar-se de pessoas com } \\
\text { quem se sinta mais seguro e } \\
\text { dizer a elas como se sente/pensa; } \\
\text { - Quando conversar com o } \\
\text { melhor amigo, em assuntos que } \\
\text { não conhece, dizer como se } \\
\text { sente (desconheço o assunto) e } \\
\text { conversar a respeito; } \\
\text { - Diminuir autojulgamentos e } \\
\text { depreciação sobre seus } \\
\text { comportamentos, facilitando a } \\
\text { aproximação com o outro; }\end{array}$ & $\begin{array}{l}\text { Respostas verbais mais descritivas } \\
\text { acerca de sentimentos e emoções, } \\
\text { aproximando o terapeuta; } \\
\text { Topografias: } \\
\text { Diante da solicitação de relato sobre } \\
\text { como se sente/pensa: } \\
\text { - Responder de maneira mais } \\
\text { descritiva suas sensações e emoções, } \\
\text { sem se julgar ou se depreciar; } \\
\text { - Verbalizar os comportamentos } \\
\text { encobertos que provocam reações } \\
\text { físicas incômodas a ele, para } \\
\text { sinalizar à terapeuta que está } \\
\text { desconfortável; } \\
\text { - Diante de um assunto que } \\
\text { desconhece, relatar que não sabe e } \\
\text { perguntar sobre o assunto, mantendo } \\
\text { a conversa com a terapeuta; }\end{array}$ \\
\hline
\end{tabular}




\section{Análise Funcional}

De acordo com a análise da história de vida do Murilo e de seus comportamentos em sessão junto ao terapeuta, pode-se perceber que o maior comprometimento funcional do cliente se dá na esfera social. Em termos de intimidade, a esquiva de relacionamentos interpessoais ocorriam com alta frequência e afastava as pessoas ao seu redor, quando ele tentava se aproximar, evitando possíveis julgamentos ou avalições, ou o contato não acontecia (na maioria das vezes), pois seu autojulgamento e autoavaliação negativos, fazia com que ele nem tentasse se aproximar.

A longo prazo, tais comportamentos tendem a afastar as pessoas que se aproximam e a reforçar seus comportamentos de isolamento social, mantendo-se sozinho a maior parte do tempo.

A cadeia comportamental predominante do repertório do cliente, com base na conceituação de caso até o término dos atendimentos, se estruturava da seguinte maneira: diante de perguntas sobre si mesmo, o que sentia ou pensava a respeito de si (antecedente) - o cliente verbaliza de maneira pouco descritiva, demonstrando pouco autoconhecimento e discriminação de sentimentos e emoções, evitando entrar em contato com seus sentimentos e vulnerabilidades, porém se julgando e depreciando bastante (encobertos verbalizados para o terapeuta) e, com isso, não se aproxima das pessoas e, quando se aproxima, as pessoas se afastam $\left(\mathrm{S}^{-}\right)$.

Considerando os déficits comportamentais que a literatura apresenta para as pessoas com ansiedade social, podemos perceber de maneira clara um grande comprometimento na esfera dos relacionamentos interpessoais, uma vez que o excesso de autojulgamento e depreciação não permitem a aproximação do cliente com outras pessoas e, quando alguma aproximação ocorre, a exposição à vulnerabilidade faz com que ele se esquive da possibilidade de um evento ansiógeno (julgamentos e avalições 
negativas). Com isso, a esquiva de relacionamentos que sinalizem intimidade e vulnerabilidade é reforçada pela retirada de um possível estímulo aversivo. Esse repertório de comportamento se repete, continuamente, ao longo da vida do ansioso social, promovendo um déficit de habilidades sociais e evitando que a pessoa se exponha.

\section{(2) Dados do instrumento de triagem M.I.N.I}

Os três participantes foram avaliados com a entrevista diagnóstica padronizada breve, que teve duração de, aproximadamente, 40 minutos para cada um. A entrevista identifica transtornos atuais e os três participantes se enquadraram na categoria "G. FOBIA SOCIAL", necessária para a participação na pesquisa. Além disso, os participantes Rodolfo e Walter se enquadraram na categoria "B. DISTIMIA", e o participante Murilo, se enquadrou na categoria “A. EPISÓDIO DEPRESSIVO MAIOR”.

\section{(3) Dados das medidas externas}

a. $\underline{O Q-45}$

O instrumento OQ-45 propõe dois tipos de avaliações, a avaliação de resultado e a avaliação da mudança significativa. A primeira, ocorre pela análise da porcentagem acima do nível clínico, e a segunda, através da análise dos escores brutos das categorias.

A porcentagem acima do nível clínico é medida por meio da relação entre o escore obtido na categoria e nível de corte clínico característico dela. Ao analisarmos a porcentagem acima do nível clínico, podemos observar quão distante ou próximo o cliente está de níveis aceitáveis e propostos por Lambert e Burlingame (1996) de uma boa qualidade de vida. A Figura 2 aponta as porcentagens acima do nível clínico para todas as categorias do instrumento OQ-45 nas primeiras e últimas sessões de cada fase experimental, durante a linha de base múltipla: 


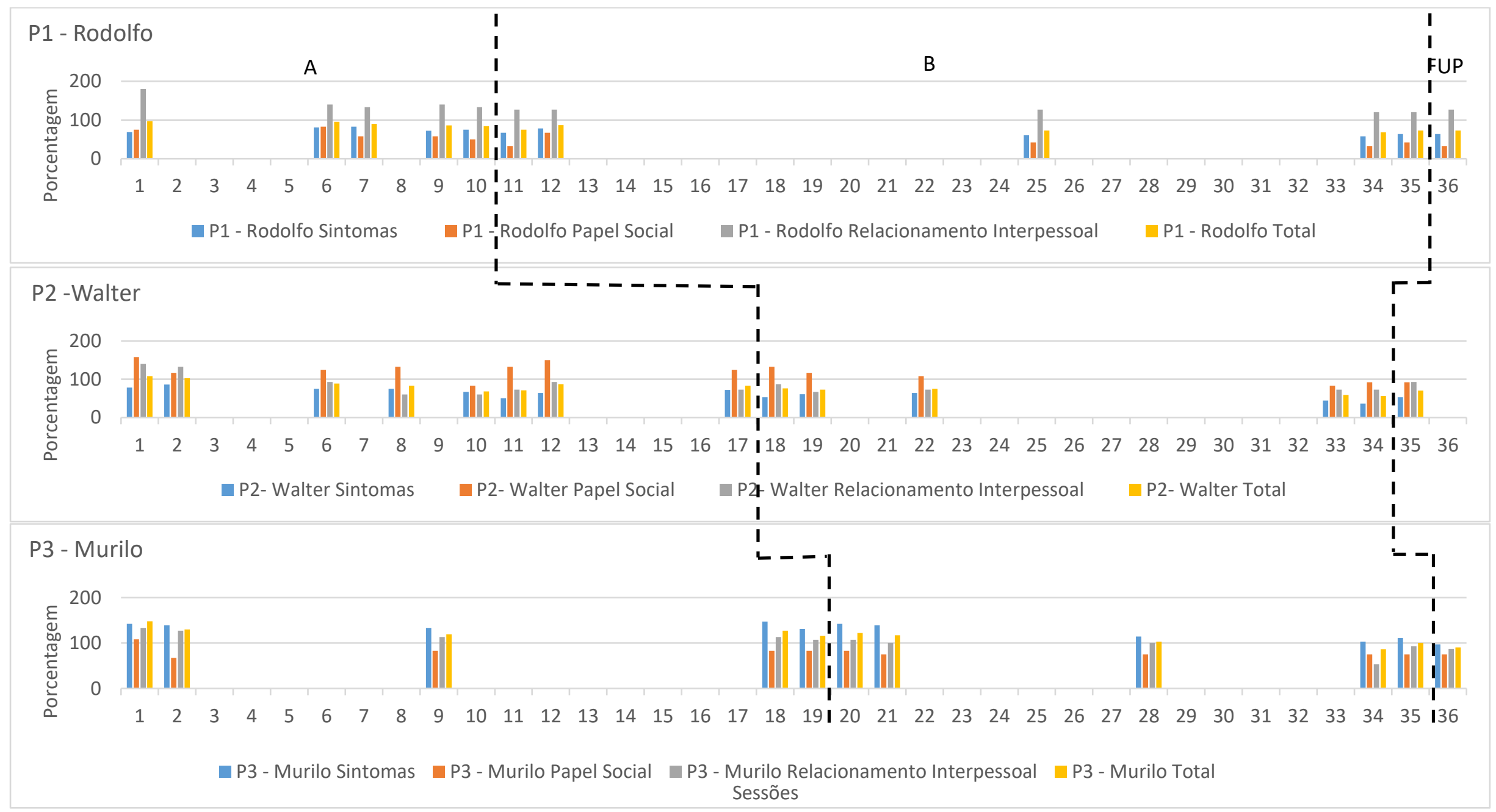

Figura 4. Porcentagem acima do nível clínico para o instrumento OQ-45, por categoria e por participante, durante a linha de base múltipla (A), a fase experimental (B) e fase de seguimento (FUP), respectivamente: (1) Rodolfo, (2) Walter e (3) Murilo. A linha tracejada indica a mudança de fase. 
Na primeira sessão da Fase A, a porcentagem acima do nível clínico foi superior nas categorias de Relacionamento Interpessoal para o cliente Rodolfo (180\%), Papel Social (158\%) e Relacionamento Interpessoal (140\%) para o cliente Walter e Desconforto Subjetivo (167\%) para o cliente Murilo. Tais porcentagens corroboram com a conceituação de caso de cada participante, a qual descreve para o cliente Rodolfo maiores dificuldades na criação de vínculos interpessoais; para o cliente Walter grande preocupação com seu papel social (indicado por cursar a faculdade de Medicina) e relacionamentos amorosos; e para o cliente Murilo, vai contra no quesito de relacionamentos interpessoais, e a questão dos sintomas, bastante aparente para este participante, não foi trabalhada diretamente, pois o terapeuta não tinha acesso aos respondentes. Ainda considerando-se a primeira sessão de cada participante, as porcentagens de Desconforto Subjetivo (SD) foram de 69\% para o Rodolfo e $78 \%$ para o Walter. Quanto à categoria de Papel Social (SR), as porcentagens foram de 75\% para o Rodolfo e $108 \%$ para o Murilo.

No decorrer do processo terapêutico, é possível perceber variações importantes nas porcentagens das categorias de Relacionamento Interpessoal e Papel Social de Rodolfo, tendo a categoria de Relacionamento Interpessoal apresentado forte tendência de queda desde o início da Fase A, podendo explicar a importância da relação terapêutica enquanto forte vínculo interpessoal, suficiente para melhorar os níveis nessa categoria. Após a introdução da FAP, na Fase B, é possível perceber uma tendência constante de queda na categoria de Relacionamentos Interpessoais, variando de $127 \%$ na primeira sessão da Fase B para 120\% na última sessão. Entre as sessões 11 e 12 da Fase B, podemos perceber uma mudança significativa nas curvas das categorias de Papel Social (de 33\% a 37\%, respectivamente) e de Desconforto Subjetivo (de 37\% para 78\%), podendo ser indicada pelo início da intervenção FAP e bastante sensibilidade do participante Rodolfo 
com as evocações e consequenciações do terapeuta. Já na sessão de seguimento, após um mês de pausa dos atendimentos, nota-se uma queda na porcentagem da categoria de Papel Social (SR), com 33\%, e constância na porcentagem de Desconforto Subjetivo (SD), com 64\%, e um leve aumento na categoria de Relacionamentos Interpessoais (IR), com 73\%, ocasionado, provavelmente, pela ausência da terapia no período de um mês e sua interferência no vínculo interpessoal com o Rodolfo.

No caso do cliente Walter, durante a Fase A, notamos grandes oscilações nas porcentagens das categorias de Papel Social (SR) e Relacionamentos Interpessoais (IR), especialmente entre as sessões 10 e 12, apesar da tendência de queda. Nas primeiras sessões da Fase A, já é possível notar uma queda significativa nessas duas categorias, variando de $158 \%$ a $83 \%$ a porcentagem de Papel Social (SR), entre as sessões 1 e 10, e $140 \%$ a $60 \%$ a porcentagem de Relacionamentos Interpessoais (IR), entre as mesmas sessões. Entre as sessões 10 e 12, nota-se um grande aumento nas porcentagens das categorias de Papel Social (SR), variando de $83 \%$ a $150 \%$, e de Relacionamentos Interpessoais (IR), variando de $60 \%$ a $93 \%$. Este aumento pode ser explicado por um evento em específico, ocorrido no intervalo destas sessões e relatado à terapeuta na sessão 12, no qual o pai de Walter quebrou alguns esmaltes do filho e a mãe escondeu algumas blusas com estampas do movimento LGBT e, com isso, Walter descreveu estar se sentindo triste, pouco acolhido e revendo a importância de se assumir sua sexualidade para os pais. Como estas duas categorias são as que se apresentavam acima do nível crítico no início no processo terapêutico, diante deste evento, essas duas categorias são as que apresentam maior influência externa. Após a sessão 12, com o acolhimento e validação da terapeuta, as duas categorias já apresentaram queda significativa, mantendo a tendência de queda após a introdução da FAP na sessão 18, com uma variação de 93\% a $73 \%$ na porcentagem de Relacionamentos Interpessoais (SR) e $150 \%$ a $92 \%$ na 
porcentagem de Papel Social (SR), ao final da Fase B. É importante destacar, também, que ao longo da Fase B, realizada no segundo semestre de 2018, o cliente estava próximo às fases de vestibular, e relatou sentir-se mais motivado a estudar e a passar logo pelos vestibulares, contribuindo para a tendência de queda das categorias. Na sessão de seguimento, após um mês de intervalo, nota-se aumento nas porcentagens das categorias de Relacionamentos Interpessoais (SR), com 93\%, e de Desconforto Subjetivo (SD), com 53\%, e constância na porcentagem da categoria de Papel Social (SR), com 92\%. Durante o intervalo, o cliente Walter foi aprovado no vestibular de Medicina da Universidade de São Paulo e na sessão de seguimento relatou o fato à terapeuta, mostrando-se muito realizado e aliviado. Ao mesmo tempo, devido à grande quantidade de novos estímulos da época, relatou que se sentia mais ansioso, física e psicologicamente, e com desafios nos novos relacionamentos interpessoais que se apresentavam no início dessa nova etapa de vida, podendo explicar o aumento das porcentagens das categorias citadas.

Para o cliente Murilo, durante toda a Fase A, a categoria que teve sua porcentagem acima do nível clínico foi a de Desconforto Subjetivo (SD), com porcentagem de 167\% na primeira sessão, e $131 \%$ na última sessão da Fase A, o que condiz com a conceituação de caso do participante, uma vez que relatava grande desconforto fisiológico por conta da ansiedade, tanto em relação ao sono, quanto aos pensamentos intrusivos frequentes. Apesar de abaixo do nível clínico, a categoria de Relacionamentos Interpessoais (IR) esteve bem próxima da linha do nível clínico durante toda a Fase A, com porcentagem de 133\% na primeira sessão e 107\% na última sessão da Fase A, estando bastante acima da categoria de Papel Social (SR), que apresentou 108\% na primeira sessão e $83 \%$ na última sessão da Fase A. A categoria de Papel Social (SR) teve uma queda importante durante as primeiras sessões, e a análise das sessões mostra que a validação do terapeuta em relação às dificuldades do cliente em voltar a estudar ou trabalhar teve papel importante 
nesse cenário e manteve-se constante ao longo da fase. Entre a última sessão da Fase A e a primeira sessão da Fase B, com a introdução da FAP, percebemos uma leve tendência de aumento nas categorias de Desconforto Subjetivo, pois neste período, Murilo relatou episódios de crises de ansiedade, ficando bastante sob controle dos sintomas físicos sentidos. As outras categorias mantiveram-se constantes e com tendência de queda até as últimas sessões, com especial atenção às categorias de Desconforto Subjetivo, passando de $142 \%$ na primeira sessão da Fase B para $111 \%$ na últimas sessão dessa fase, devido ao manejo da ansiedade do participante junto ao terapeuta em sessão, e de Relacionamentos Interpessoais, passando de 107\% na primeira sessão da Fase B para 93\% na última sessão dessa fase, condizendo com o momento de estabilidade vivida por Murilo após maior controle de sua ansiedade e volta à rotina, retornando o encontro com o amigo e fazendo novas parcerias, além de ter feito seu primeiro trabalho como ilustrador de um livro.

Na sessão de seguimento, após um mês de intervalo, houve queda nas porcentagens da categoria de Desconforto Subjetivo (SD), com 97\%, de Relacionamentos Interpessoais (IR), com $87 \%$ e manutenção na porcentagem da categoria de Papel Social (SR), com $75 \%$. A porcentagem total, portanto, caiu para $90 \%$. Esses resultados condizem com o relato de Murilo à respeito dos acontecimentos neste tempo de intervalo, afirmando ter se sentido estável, controlando a ansiedade e seus episódios, bem como retornando à algumas atividades que havia deixado de realizar após os episódios de ansiedade (desenhar, estudar, ir na casa do amigo e familiares).

O OQ-45 também pode ser interpretado por meio da pontuação bruta, que nos fornece informação sobre a avaliação da mudança significativa. A pontuação que oferece dados para a avaliação da mudança significativa deve indicar uma queda de 10 pontos na categoria de Desconforto Subjetivo (SD), 8 pontos na categoria de Relacionamentos 
Interpessoais (IR), 7 pontos na categoria de Papel Social (SR) e 14 pontos na pontuação total, ao longo de todo o processo terapêutico.

O cliente Rodolfo apresentou mudança significativa na pontuação total, que caiu 14 pontos entre a primeira sessão da Fase A e a última sessão da Fase B. Na categoria de Desconforto Subjetivo (SD), a queda de pontos entre a primeira sessão da Fase A e a última sessão da Fase B foi de 1 pontos, apenas, o que pode ser explicado pelas queixas em relação ao sono e à falta de atividade física, que se manteve durante todo o processo terapêutico. Na categoria de Relacionamentos Interpessoais (IR), categoria mais afetada neste cliente, a queda foi de 8 pontos entre a primeira sessão da Fase A e a última sessão da Fase B, indicando pontuação suficiente para uma mudança significativa. Em relação à categoria de Papel Social (SR), a queda foi de 5 pontos, contra 7 necessários para uma mudança significativa. Quando comparamos as pontuações da primeira sessão da Fase A com a sessão de seguimento, poucas são as mudanças. A categoria de Desconforto Subjetivo (SD) caiu 2 pontos; de Relacionamento Interpessoais (IR) caiu 8 pontos; de Papel Social (SR) caiu 5 pontos; e na pontuação total, houve queda de 15 pontos. Esses dados revelam que, após intervalo de um mês para a sessão de seguimento, a pontuação se manteve similar à pontuação da última sessão da Fase B, indicando que os resultados foram reforçados e generalizados ao longo do processo.

$\mathrm{O}$ cliente Walter apresentou pontuações muito próximas ou superiores às necessárias para uma mudança significativa em todas as categorias. Na categoria de Desconforto Subjetivo (SD), a pontuação caiu 15 pontos, de 64 na primeira sessão da Fase A para 49 na última sessão da Fase B. Na categoria de Relacionamentos Interpessoais (IR), a pontuação foi de 36 prontos na primeira sessão da Fase A para 26 pontos na última sessão da Fase B, com queda de 10 pontos. Em relação ao Papel Social (SR), categoria mais acometida e que estava acima do nível clínico na primeira sessão da 
Fase A, a queda foi de 31 pontos para 23 pontos entre a primeira sessão da Fase A e a última sessão da Fase B, com queda de 8 pontos, superando em 1 ponto a pontuação necessária para a mudança significativa nesta categoria. Em relação à pontuação total, entre a primeira sessão da Fase A e a última sessão da Fase B, a queda foi de 33 pontos, superando em 19 pontos a pontuação necessária para uma mudança significativa em relação aos pontos totais. Em relação à sessão de seguimento, a pontuação bruta se modificou, mas ainda próxima da pontuação necessária para a mudança clínica. $\mathrm{Na}$ categoria de Desconforto Subjetivo (SD), a pontuação variou de 49 pontos na última sessão da Fase B para 55 pontos na sessão seguimento. Na categoria de Relacionamentos Interpessoais (IR), a pontuação foi de 26 para 29. Na categoria de Papel Social (SR), a pontuação não teve variação. Esses dados indicam que, apesar da variação, a pontuação se manteve próxima ou superior à necessária para a mudança significativa em relação às categorias e, a categoria que se apresentava acima do nível clínico na primeira sessão da Fase A, Papel Social (SR), manteve-se acima do nível clínico, porém teve queda suficiente para indicar uma mudança significativa.

No caso do Murilo, as pontuações para atingir a mudança significativa nas categorias chegaram muito próximas às necessárias ou foram superiores. Na categoria de Desconforto Subjetivo (SD) a pontuação caiu 20 pontos, de 96 na primeira sessão da Fase A para 76 na última sessão da Fase B, ultrapassando em 10 pontos a pontuação necessária para atingir a mudança significativa. Na categoria de Relacionamentos Interpessoais (IR) a pontuação caiu 6 pontos, de 35 pontos na primeira sessão da Fase A para 29 pontos na última sessão da Fase B, não atingindo a pontuação de 8 pontos necessária para a mudança significativa nesta categoria. Na categoria de Papel Social (SR) a pontuação caiu 4 pontos, de 25 pontos na primeira sessão da Fase A para 21 pontos na última sessão da Fase B, também não atingindo a pontuação de 7 pontos necessária para atingir a mudança 
significativa. Em relação à pontuação total, a queda foi superior à necessária para atingir a mudança significativa, com 30 pontos ao final da última sessão da Fase B. Quando comparamos as pontuações entre a primeira sessão da Fase A e a sessão de seguimento, notamos uma queda de mais 5 pontos na categoria de Desconforto Subjetivo (SD), com 71 pontos, 7 pontos na categoria de Relacionamentos Interpessoais (IR), com 28 pontos, manutenção da pontuação de queda de 4 pontos para a categoria de Papel Social (SR), com 21 pontos e, em relação à pontuação total, queda de mais 6 pontos, com pontuação final de 120 .

\section{b. $\underline{B D I}$}

A escolha do instrumento BDI deveu-se ao fato da comorbidade associada à ansiedade social. Comumente, esse diagnóstico está presente junto a outros, como a depressão, uma vez que os prejuízos que a ansiedade social acarreta nos indivíduos que a apresentam estão especialmente relacionados ao isolamento social e solidão. O BDI fornece uma estimativa global da depressão em quatro níveis, de acordo com a pontuação atingida: depressão mínima (0 a 11 pontos), depressão leve (12 a 19 pontos), depressão moderada (20 a 35 pontos) e depressão grave (36 a 63 pontos). O M.I.N.I já havia indicado que os participantes Rodolfo e Walter apresentavam sintomas de distimia e o participante Murilo de episódio depressivo maior. A seguir, a Figura 3 mostra a pontuação bruta do instrumento BDI para os três participantes, de acordo com as fases experimentais durante a linha de base múltipla: 


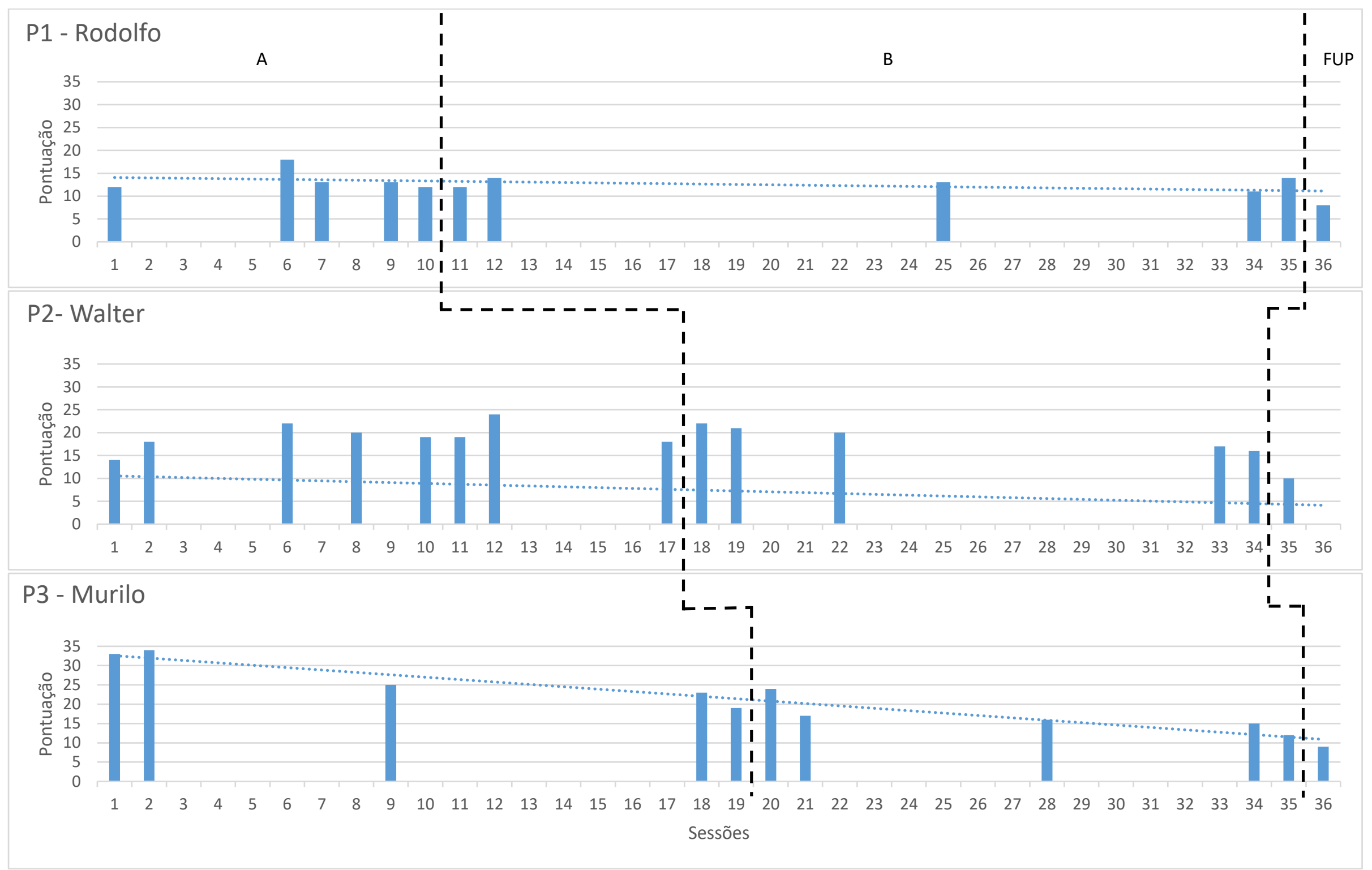

Figura 5. Pontuação bruta para o instrumento BDI, por participante, durante a linha de base múltipla para (1) Rodolfo, (2) Walter e (3) Murilo. Legenda: A = Linha de base; $\mathrm{B}=$ FAP e FUP = seguimento. A linha tracejada preta indica a mudança de fase. 
A partir da conceituação de caso dos três participantes e do instrumento M.I.N.I, percebeu-se que sintomas depressivos eram presentes em maior escala no participante Murilo, até pelo pouco acesso a reforçadores. Enquanto Rodolfo já havia terminado a faculdade e conseguido um emprego, e Walter estudava há seis anos para o vestibular e, desses, dois foram em cursinho, no qual fez amigos que manteve até os dias de hoje, Murilo acabou o ensino médio e não ingressou em nenhuma outra atividade, estando em casa desde então e tendo apenas um amigo com quem socializava com frequência. Assim, o isolamento social de Murilo é muito maior que dos outros dois participantes.

Desde a primeira sessão da Fase A, Rodolfo obteve uma pontuação bruta baixa no instrumento, caracterizando um grau leva para a depressão. Durante toda a Fase A o índice se manteve, com poucas e pequenas variações. Do mesmo modo, na primeira sessão Fase B, a pontuação foi de 12 pontos, indicando grau leve para a depressão. Esse índice se manteve durante toda a fase, caindo para o grau mínimo na penúltima sessão desta fase. Na sessão de seguimento, foi alcançada a pontuação mais baixa, de 8 pontos, indicando grau mínimo para a depressão.

No caso do cliente Walter, houve mais variações, tanto da pontuação, quanto do grau da estimativa da depressão. Na primeira sessão da Fase A, Walter obteve a pontuação de 14 pontos, indicando um grau leve de depressão. Ao longo desta fase, houve variações de 4 a 6 pontos, aumento o grau para moderado. Essa mudança pode ser indicada por eventos específicos da época, relatados pelo participante, referente a não estar conseguindo estudar e sentindo-se pouco motivado a realizar qualquer atividade. Além disso, estava tendo problemas para conseguir dormir e acordava muito cansado, não conseguindo manter um ritmo de estudos. Como a questão do vestibular e do papel social eram de extrema importância para o participante, atividades relacionadas a essas questões interferiam muito em seu humor e satisfação de vida. A Fase B teve início com uma 
pontuação de 22 pontos, indicando um grau moderado e, no decorrer da fase, a pontuação baixou para o grau leve, tendo na fase de seguimento atingido a menor pontuação, de 10 pontos, alcançado o grau mínimo para depressão. Esse dado pode ser explicado através de um evento específico da época da sessão de seguimento. Nesta, o participante havia acabado de receber a resposta que havia sido aprovado no vestibular para Medicina da Universidade de São Paulo, seu maior sonho. Assim, como a questão de passar no vestibular percorreu todo o processo terapêutico, uma vez alcançado, Walter relatou estar se sentindo muito realizado e aliviado, como se um peso tivesse saído de suas costas.

Já o participante Murilo havia apresentado sintomas depressivos a partir do instrumento M.I.N.I (episódio de depressão maior) e relatou muitos sintomas de depressão na primeira fase do experimento, como apontado na conceituação de caso. Desde a primeira sessão da Fase A, a pontuação do participante foi de 33 pontos, muito acima da de Rodolfo e Walter para a mesma sessão (12 e 14, respectivamente), indicando um grau moderado para depressão. Ao longo da Fase A, a pontuação continuou a classificação de moderada, porém abaixou até a pontuação de 19 pontos, na última sessão da Fase A, indicando um grau leve para depressão. A pontuação manteve sua tendência de queda até a última sessão da Fase B, atingindo 12 pontos. Na sessão de seguimento, a pontuação caiu para 9 pontos, menor pontuação durante todo e delineamento, indicando grau mínimo para depressão. Esses dados contribuem com as hipóteses levantadas na conceituação de caso de que a reclusão social e pouco acesso a reforçadores mantinham um estado depressivo de Murilo, e a relação terapêutica estabelecida com a terapeuta somada às saídas de casa para ir até a clínica, foram importantes para a criação de novos reforçadores, diminuindo os sintomas depressivos.

A avaliação e interpretação do BDI aponta a necessidade de atenção a dois itens especiais, que se obtiverem pontuação de 2 ou 3 pontos, podem indicar ideação suicida: 
itens 2 (pessimismo) e 9 (pensamentos ou desejos suicidas). Os três participantes apresentam pontuação inferior a 2 pontos para os dois itens, indicando que não apresentam indícios de ideação suicida.

Ainda, é possível observar ao longo das sessões as categorias que obtiveram maiores pontuações. No caso do Rodolfo, algumas categorias apareceram em quase todas as sessões ao longo de todo o experimento com pontuação altas ( 2 a 3), sendo elas a categorias 3 (fracasso passado), 5 (sentimento de culpa), 8 (autocrítica) e 14 (desvalorização). Todas essas categorias avaliam pensamentos e sentimentos observados na conceituação de caso deste participante, uma vez que Rodolfo apresentava repertório de culpabilização de si próprio, sentimentos de fracasso por seu passo, excesso de autocrítica e desvalorização de si. Ao longo da Fase A, percebe-se que a pontuação cai para algumas categorias, até diminuir o número de categorias pontuadas por sessão. A partir da $6^{\text {a }}$ sessão, ao invés de 5 ou 4 itens pontuados, tem-se apenas 3 com pontuação significativa ( 2 a 3 pontos). Na primeira sessão da Fase B, tem-se apenas 2 categorias com pontuação alta. Um dado importante é que durante a Fase B, a categoria 3 (fracasso passado) apareceu apenas duas vezes, retornando na última sessão e na sessão de seguimento. É possível observar também que, na última sessão da Fase B e na sessão de seguimento, o número de categorias voltou a aumentar, podendo indicar um desconforto com o fim do processo terapêutico.

Para o participante Walter, as categorias que apareceram em quase todas as sessões durante o processo terapêutico foram a 10 (choro), 14 (desvalorização) e 16 (alterações no padrão de sono), o que corrobora com a conceituação de caso feita, na qual Walter relatava um incômodo com o fato de não conseguir chorar, e sentir que o choro poderia aliviar seus sentimentos, com a depreciação de sua imagem, com muitas questões ligadas à autoestima, e com as dificuldades em relação ao sono (conseguir dormir). Nas 
sessões 6 e 8 , um número grande de categorias apareceram pontuadas, sendo um total de 6 categorias em média, contra 3 nas demais sessões. Esse dado pode ser explicado devido a um evento específico ocorrido entre as sessões 6 e 8 , nas quais o pai de Walter jogou fora seus esmaltes e o insultou, bem como o cliente descobriu que sua mãe escondeu uma camisa sua com estampa LGBT, e relatou ter ficado bastante chateado e desanimado com essa situação. De forma geral, Walter apresentou pouca variação no instrumento, com uma variação significativa durante o evento citado acima, e na sessão de seguimento, atingindo a menor pontuação (10 pontos), relacionada ao resultado do vestibular. Nesta sessão, Walter encontrava-se aliviado e muito contente.

Para Murilo, as categorias que apareceram em quase todas as sessões foram a 14 (desvalorização), 3 (fracasso passado), 6 (sentimentos de punição) e 10 (choro), as quais se relacionam com a conceituação de caso deste participante, uma vez que apresentava excesso de autojulgamento e desvalorização de si mesmo e culpava-se pelo passado. A tendência de queda na pontuação deste instrumento durante todo o processo terapêutico reflete à diminuição das categorias selecionadas e pontuadas. Assim, das 21 categorias do instrumento, apenas 7 foram selecionadas e com baixa pontuação, indicando o melhor resultado em termos de queda de pontuação dentre os três participantes.

\section{c. $\underline{L S A S}$}

A Escala de Liebowitz para a Ansiedade Social avalia situações de desempenho e de interação social, das quais os indivíduos com TAS evitam ou temem, mensurando a ocorrência de ansiedade decorrente de contatos sociais. Assim, a pontuação total indica uma medida da intensidade da fobia social no momento presente, variando de acordo com a seguinte classificação: fobia social moderada (55 a 65 pontos), fobia social média (66 a 80 pontos), fobia social grave (81 a 95 pontos) e fobia social muito grave (pontuação 
acima de 95 pontos). A seguir, a Figura 4 mostra a pontuação bruta para o instrumento LSAS para todos os participantes, durante a linha de base múltipla: 


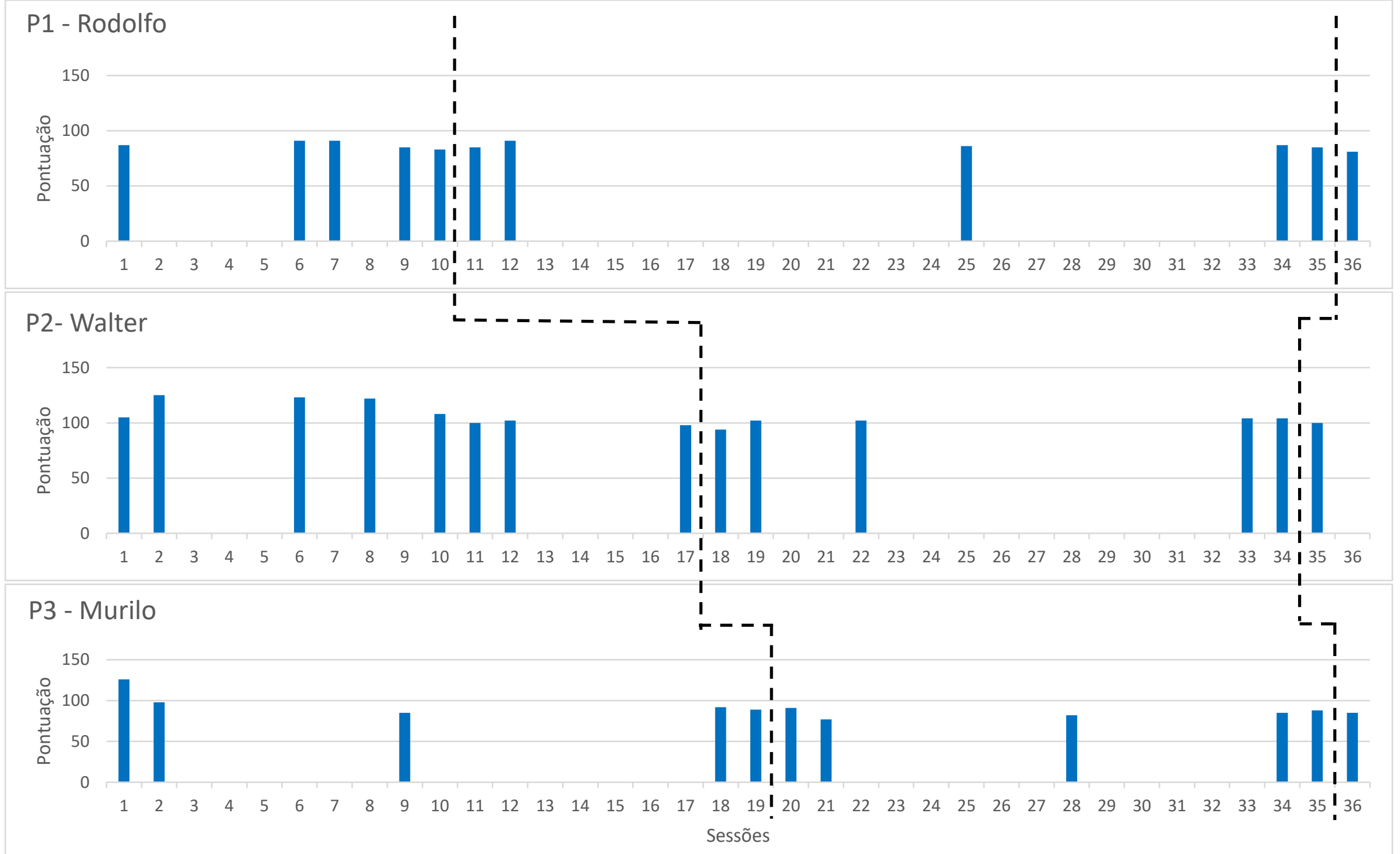

Figura 6. Pontuação bruta para o instrumento LSAS, por participante, (1) Rodolfo, (2) Walter e (3) Murilo, no decorrer das sessões. Legenda: A = linha de base; $\mathrm{B}=$ FAP e FUP = seguimento. A linha tracejada preta indica mudança de fase. 
Os três participantes iniciaram a primeira sessão da Fase A com uma pontuação elevada, sendo que Rodolfo se enquadrou em fobia social grave (87) e Walter e Murilo, em fobia social muito grave (105 e 126, respectivamente). Essa diferença pode ser explicada de acordo com a conceituação de caso e exposição a situações de interação social de cada participante. Rodolfo, mais velho, já havia terminado a faculdade e conseguiu um emprego logo no início da pesquisa, aumentando seu acesso a situações sociais e seus reforçadores. Ao passo que Walter estudava em casa sozinho há dois anos, sem muita convivência social, e Murilo também mantinha um isolamento intenso, sem muito contato social inclusive com a família. As questões dos instrumentos referem-se, em sua maioria, a situações de interações sociais em ambiente externo (fora de casa), o que pode explicar as pontuações de intenso medo/ansiedade e evitação dadas pelos participantes no instrumento.

O cliente Rodolfo iniciou a primeira sessão da Fase A com uma pontuação de 87 pontos, indicando fobia social grave. Durante toda a Fase A, a pontuação se manteve dentro da intensidade de fobia social grave, mas com oscilações importantes. Na última sessão da Fase A, a pontuação diminuiu para 83 pontos, ficando mais próxima de uma fobia social média, e podendo indicar que a relação terapêutica estabelecida durante essa primeira fase foi importante para um exposição de desempenho social do participante. Após a primeira sessão da Fase B, a pontuação voltou a subir, atingindo 91 pontos e uma intensidade de fobia social grave. Isto pode ser explicado, pois Rodolfo era bastante sensível a intervenções diretas e o início da FAP pode ter sido aversivo, uma vez que a terapeuta passou a consequenciar os seus CRB's. Ao longo da Fase B, é possível observar uma tendência de queda, de 91 pontos após a primeira sessão FAP, para 85 pontos na última sessão FAP, ainda se mantendo dentro da classificação de fobia social grave. Na 
sessão de seguimento, a pontuação baixou para 81 pontos, pontuação mínima para a classificação de fobia social grave, podendo explicar o retorno ao contato social de intimidade e segurança que o cliente estabeleceu com a terapeuta e a manutenção dos resultados do processo terapêutico. Ao longo de toda a pesquisa, a média da pontuação para Rodolfo foi de 86,5, mantendo-se dentro da classificação de fobia social grave.

O cliente Walter iniciou a primeira sessão da Fase A com uma pontuação alta, de 105 pontos, indicando uma fobia social muito grave, o que tem relação com o baixo acesso a situações de interação social fora de casa, situações essas priorizadas no instrumento. Ao longo da Fase A, nota-se um aumento na pontuação no decorrer das sessões, o que condiz com o relato do cliente de que falar sobre essas situações o deixava mais ansioso. Então, o relato tinha caráter aversivo e pode explicar o aumento da pontuação. Porém, ao longo da Fase B, a pontuação manteve tendência de queda, baixando de 125 pontos na segunda sessão da Fase A, para 98 pontos na última sessão da Fase A. A pontuação manteve uma média de 102 pontos nesta fase, mas ainda classificada em fobia social muito grave. Na sessão de seguimento, essa pontuação caiu para 100 pontos.

No caso do cliente Murilo, a pontuação na primeira sessão da Fase A foi a mais alta entre os três participantes, com 126 pontos, indicando fobia social muito grave. Isto pode ser explicado, pois este cliente encontrava-se num estado depressivo, conforme o instrumento M.I.N.I indicou, juntamente com a conceituação de caso. Ao longo de toda a Fase A a pontuação manteve uma tendência de queda, com pontuação de 89 pontos na última sessão desta fase, já indicando uma classificação de fobia social grave. A queda na pontuação durante essa primeira fase pode ser explicada pela relação terapêutica estabelecida. Na primeira sessão da Fase B, a pontuação aumentou em 2 pontos, porém manteve tendência de queda até o final da Fase B, atingindo 88 pontos na última sessão 
desta fase e 85 pontos na sessão de seguimento. Como Murilo apresentava intensa reclusão social, ficando em casa e tendo contato com apenas um amigo, a terapeuta pode ter se tornado fonte de reforçamento social, e a criação de um vínculo terapêutico suficiente, até então, para abaixar os níveis de sentimentos e pensamentos depressivos

\section{d. $\underline{\text { SPIN }}$}

O SPIN avalia três importantes critérios que definem a fobia social: o medo, a esquiva de situações e os sintomas de desconforto físico. A pontuação total varia de 0 a 68 pontos e a pontuação de corte que indica sintomas compatíveis com o diagnóstico de fobia social é de 19 pontos ou mais. A seguir, a Figura 5 apresenta a pontuação bruta do instrumento SPIN para os três participantes, durante a linha de base múltipla: 


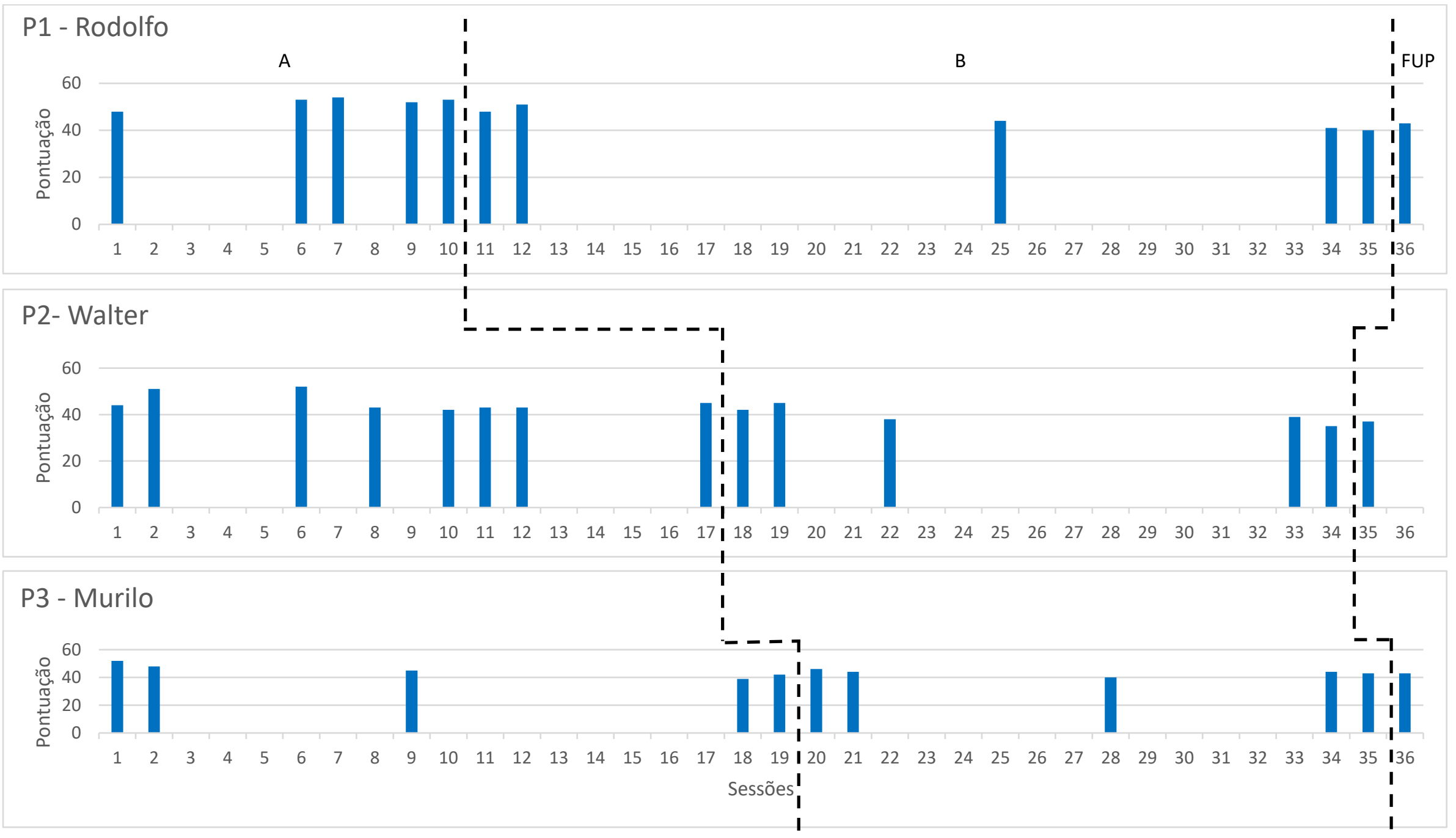

Figura 7. Pontuação bruta para o instrumento SPIN para os participantes (1) Rodolfo, (2) Walter e (3) Murilo, no decorrer das sessões. Legenda: A = linha de base; $\mathrm{B}=\mathrm{FAP}$ e FUP = seguimento. A linha tracejada preta indica mudança de fase. 
Conforme podemos observar nos gráficos acima, os três participantes apresentam pontuação superior a 19 pontos em toda as sessões, durante todas as fases da pesquisa. Portanto, todos apresentam sintomas compatíveis com o diagnóstico de fobia social, revelando medo, esquiva de situações e sintomas de desconforto físico nas situações propostas pelo instrumento.

O participante Rodolfo foi o que apresentou maiores pontuações durante as sessões (média de 47,9 pontos), e o participante Walter e Murilo, pontuações menores (médias de 42,60 e 44,18 respectivamente). Um dado relevante é que durante as sessões da Fase A, a pontuação de Rodolfo teve um aumento, de 48 pontos na primeira sessão da Fase A, para 53 pontos na última sessão da mesma fase. Após a primeira sessão FAP, na Fase B, a pontuação manteve tendência de queda, de 48 pontos na primeira sessão da Fase B, para 40 pontos na última sessão desta fase, e 43 pontos na sessão de seguimento. Já para o participante Walter, a pontuação variou de 44 pontos na primeira sessão da Fase A para 45 pontos na última sessão dessa fase, tendo atingido a maior pontuação de todo o processo na sessão 6, com 52 pontos (vale lembrar que esta sessão obteve maiores pontuações em todos os instrumentos, por um evento específico da época, em que Walter se via apaixonado por um rapaz e pensando nele o tempo todo). Após a primeira sessão da Fase B, com introdução da FAP, a pontuação caiu de 45 pontos na última sessão da Fase A, para 35 pontos na última sessão da Fase B e 37 pontos na sessão de seguimento. No caso de Murilo, a pontuação iniciou com 52 pontos na primeira sessão da Fase A e teve uma tendência de queda até a penúltima sessão desta fase, com 39 pontos. Após a primeira sessão FAP, dando início à Fase $\mathrm{B}$, mas teve tendência de queda até a última sessão desta fase, com 43 pontos, e a mesma pontuação na sessão de seguimento. $\mathrm{O}$ aumento da pontuação neste instrumento nas sessões da Fase B pode ser explicado pelos episódios de crise de ansiedade de Murilo. Neste período, o participante teve três 
episódios de crise de ansiedade, tendo um deles sido levado ao hospital. Assim, durante algumas sessões, foi trabalhado o tema da ansiedade e como manejá-la.

\section{(4) Escala de Avaliacão da Psicoterapia Analítica Funcional (FAPRS).}

Com o objetivo de categorizar gravações de vídeos e áudios das sessões de terapia, o instrumento FAPRS possibilita o registro e análise dos comportamentos do cliente e terapeuta em sessão, podendo fornecer informações para observar possível mudanças de comportamentos. O registro ocorre sequenciando as respostas verbais, tanto do cliente, quanto do terapeuta, possibilitando o estabelecimento de uma relação entre as respostas do terapeuta sobre as respostas do cliente.

Levando-se em conta o delineamento experimental desta pesquisa, conforme mostram os gráficos abaixo, o tempo da Fase A (linha de base) e da Fase B (introdução da VI - FAP) foi diferente para cada participante. Rodolfo e Murilo tiveram um total de 35 sessões, seguidas de uma sessão de seguimento. Walter teve um total de 34 sessões, seguida da sessão de seguimento (não foi possível completar as 35 sessões devido às faltas do participante). De acordo com o delineamento de linha de base múltipla, quando a intervenção é iniciada para um participante, o segundo participante continua em linha de base, e assim por diante com os outros participantes, a depender da estabilidade da tendência. Dessa forma, o participante Rodolfo atingiu estabilidade da tendência dos CRBs descritos na conceituação de caso com 10 sessões. A partir da $11^{\mathrm{a}}$ sessão, introduziu-se a FAP, dando início à Fase B. O participante Walter continuou, portanto, em linha de base e, quando atingiu a estabilidade de tendência dos CRBs descritos na conceituação de caso, com 17 sessões, passou para a Fase B. Assim, o participante Murilo continuou em linha de base e, quando atingiu estabilidade da tendência dos CRBs, com 19 sessões, passou para a Fase B. Assim, o tempo de exposição à VI - FAP na Fase B foi 
de 25 sessões para o participante Rodolfo, 17 sessões para o participante Walter e 16 sessões para o participante Murilo (devido à grande quantidade de faltas do participante, foram feitas duas sessões de terapia por semana e tiveram de ser encerradas para a conclusão da escrita da pesquisa). É importante destacar que a longa duração de linha de base para a estabilidade de tendência dos comportamentos nos participantes dessa pesquisa, se relaciona ao diagnóstico de ansiedade social dos participantes, considerando a dificuldade em estabelecer um vínculo e descrever a conceituação de caso, dado o padrão de esquiva dos clientes por medo de julgamento e avaliação da terapeuta, e as faltas durante o experimento.

Primeiramente, serão apresentados os dados dos comportamentos clinicamente relevantes de problema e de melhora (CRB1 e CRB2, respectivamente); em seguida, os comportamentos do terapeuta (Regras $1,2,3,4,5)$; e por último, a relação entre os comportamentos do cliente e do terapeuta durante as fases do experimento.

Para dar início a essa análise, a Figura 6 abaixo mostra a porcentagem de frequência dos comportamentos dos clientes (CRB1 e CRB2) ao longo do delineamento experimental: 


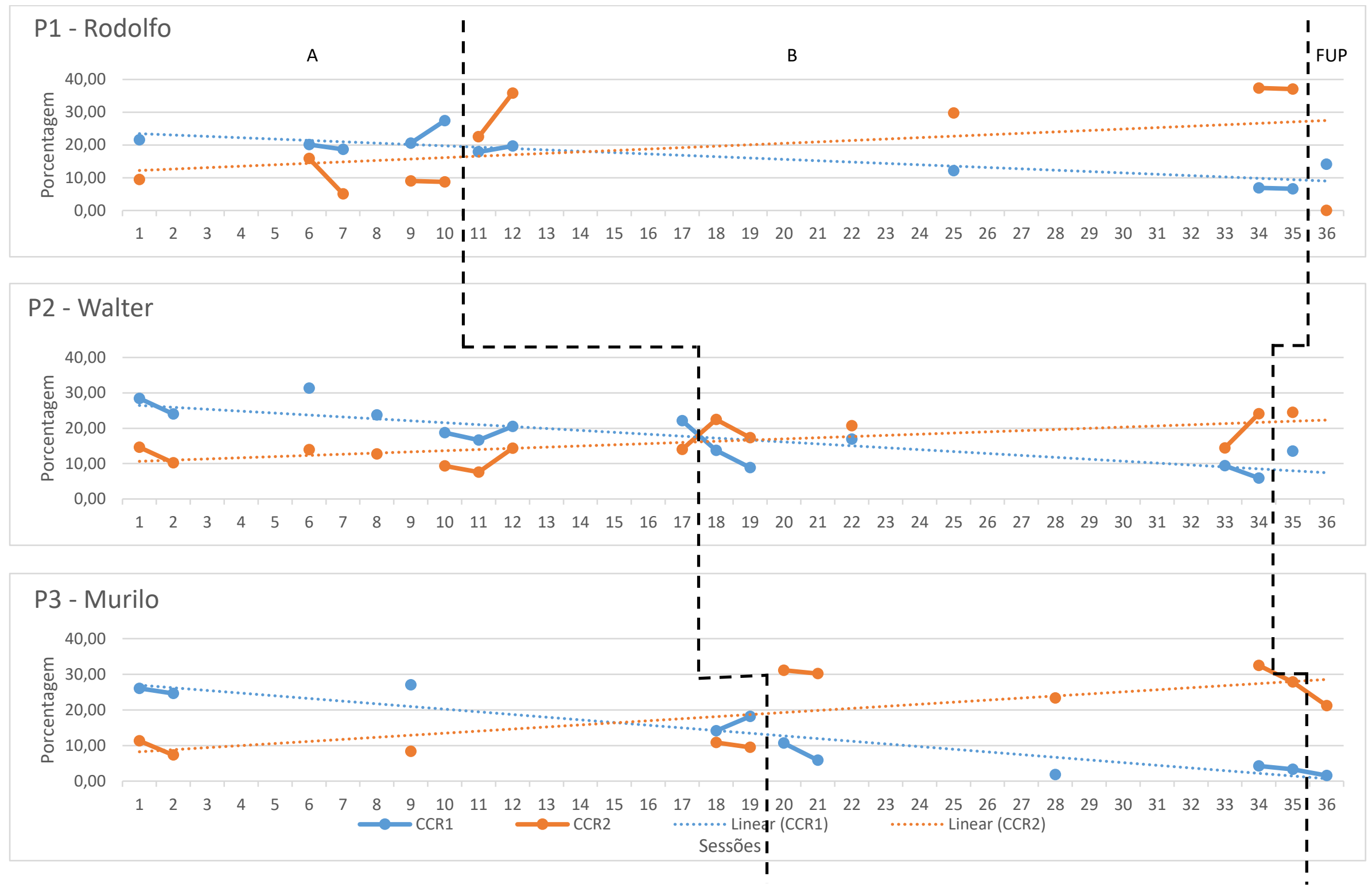

Figura 8. Frequência dos comportamentos do cliente: CRB1 e CRB2, ao longo do delineamento experimental, por participante: (1) Rodolfo, (2) Walter e (3) Murilo. Legenda: A= linha de base; B = FAP e FUP = seguimento. A linha preta tracejada indica mudança de fase. 
Os resultados referentes aos comportamentos dos clientes são apresentados na Figura 6, pela porcentagem de comportamentos clinicamente relevantes (CRB1 e CRB2) ao longo das sessões do delineamento experimental. Na primeira sessão da Fase A, podemos observar uma porcentagem elevada de CRB1 para os três participantes (Rodolfo, 21,57\%; Walter, 28,44\%; e Murilo, 26,04\%), em contraposição à baixa porcentagem de CRB2 para os participantes (Rodolfo, 9,47\%; Walter, 14,65\%; e Murilo, 11,33\%). O participante Murilo apresentou a maior diferença de porcentagem entre CRB1 e CRB2 durante a Fase A (diferença de 18,63\% na sessão 9), o que pode ser explicado de acordo com a conceituação de caso, já que o CRB1 do participante consistia em respostas pouco descritivas e bastante genéricas a respeito de si e do outro, aparecendo em qualquer solicitação de relato que a terapeuta pedia para ser feita. É importante notar que ao longo de toda a Fase A, para todos os participantes, as porcentagens de CRB1 e CRB2 se mantiveram maiores para CRB1, com pontuação máxima de 24,41\% para Rodolfo, 31,32\% para o Walter e $27,01 \%$ para o Murilo, e menores para CRB2, com pontuação mínima de 5,05\% para Rodolfo, 7,59\% para Walter e 7,31\% para Murilo.

Após a introdução da variável independente, FAP (sinalizada pela linha sólida preta), observa-se uma reversão nas porcentagens dos CRBs para todos os participantes, sendo que essa reversão ocorreu logo após a primeira sessão da Fase B para todos. Comparando-se as reversões das porcentagens de CRBs entre Rodolfo e Murilo, nota-se que durante toda a Fase A houve tendência de queda na porcentagem de CRB1 e de subida na porcentagem de CRB2 no caso de Murilo, o que condiz com sua conceituação de caso no que se refere à falta de relacionamentos interpessoais, ficando bastante sensível às alterações de respostas da terapeuta, a qual estabelecia-se, praticamente, como o único vínculo interpessoal deste participante, e ao maior tempo de Fase A, ocasionando uma criação de vínculo mais intensa, dado que nesta Fase A conceituação de caso foi efetuada, 
juntamente com algumas análises de contingências externas, quando necessárias. No caso de Rodolfo, também é possível notar uma queda nas porcentagens de CRB1 e aumento nas porcentagens de CRB2 durante a Fase A, porém com uma oscilação importante entre as sessões 6 e 7, devido a um evento específico entre as sessões, no qual Rodolfo relatou incômodo sobre o gravador e que teria exagerado nos relatos sobre os pais, sentindo-se culpado, aumentando a porcentagem de CRB1 e diminuindo a porcentagem de CRB2. Entre a última sessão da Fase A e a primeira sessão analisada da Fase B, as porcentagens de CRB1 caíram de 24,41\% para 17,86\% em Rodolfo, de 22,14\% para 16,95\% em Walter e 18,15\% para 10,64\% em Murilo. Já as porcentagens de CRB2 entre essas mesmas sessões subiram de $8,7 \%$ para $22,47 \%$ em Rodolfo, de $14,02 \%$ para 20,68\% em Walter e de $9,52 \%$ para $31,12 \%$ em Murilo.

Ao analisar as porcentagens de CRBs após a introdução da FAP, portanto, notamos uma tendência de aumento significativo de CRB2 e queda abrupta de CRB1, fato que também foi observado em outros estudos com delineamento de sujeito único (Aranha, no prelo; Moreira, 2018; Lima, 2017; Mangabeira, 2014; Oshiro, 2011; Vartanian, 2017; e Villas-Bôas, 2015). Nestas pesquisas, apesar dos diagnósticos distintos, os clientes também apresentavam comprometimento nas relações interpessoais. Já em relação à oscilação de CRBs ao longo da fase FAP para os participantes, Busch et al (2010) apontam que os CRBs acontecem de maneira natural, podendo ou não serem evocados pelo terapeuta. Além disso, fatores externos no cotidiano do cliente também influenciam na ocorrência dos CRBs.

De modo geral, a tendência de queda de CRB1 e aumento de CRB2 durante o processo terapêutico, revela um processo terapêutico bem-sucedido, no qual houve aprendizagem ao longo do tempo e não apenas após a introdução da FAP. Quando observamos a linha de tendência de maior ângulo de crescimento de CRB2, percebemos 
que ela ocorre para o participante com maior exposição à FAP, Rodolfo. Da mesma forma, a maior diferença entre as linhas de tendência de CRB1 e CRB2 também acontecem com este cliente, e se relacionam ao maior tempo de exposição à FAP.

Conforme já mencionado, durante a Fase B, após introdução da FAP, houve inversão das porcentagens de CRB1 e CRB2 para todos os participantes. No participante Rodolfo, a porcentagem de CRB2 subiu entre a primeira e a última sessão da Fase B de $22,47 \%$ para $37,1 \%$, enquanto a porcentagem de CRB1 caiu, entre as mesmas sessões, de 17,86\% para 6,94\%. No caso de Walter, entre a primeira sessão da Fase B analisada e a última da mesma fase, a porcentagem de CRB2 subiu de 20,68\% para $24,11 \%$, enquanto a queda da porcentagem de CRB1 entre as mesmas sessões foi de $16,95 \%$ para $5,92 \%$. Para o participante Murilo, a porcentagem de CRB2 teve uma queda entre a primeira sessão da Fase B e a última, de 31,12\% para 27,85\%. Porém, a porcentagem de CRB1caiu de 10,64\% na primeira sessão da Fase B para 3,28\% na última sessão. Se compararmos a diferença entre a porcentagem de CRB2 e CRB1 ao final da Fase B para cada participante, observamos uma maior diferença no caso de Rodolfo, com 30,16\%. Walter teve uma diferença de $18,19 \%$ e Murilo de 24,85\%. Essa diferença pode ser explicada pelo tempo de exposição à FAP de cada participante. Rodolfo teve 25 sessões na Fase B, comprovando que quanto maior o tempo de exposição à FAP, maiores os efeitos dessa intervenção. Walter, com 17 sessões na Fase B, teve uma diferença menor entre as porcentagens de CRB2 e CRB1 ao final desta fase, e Murilo, com 16 sessões FAP, teve uma diferença maior que de Walter, porém menos que de Rodolfo. O caso de Murilo continua revelando um diferencial importante no quesito fator externo: é o único cliente com acesso restrito a reforçadores, sendo a terapeuta sua única relação interpessoal extra ambiente familiar e, com isso, o cliente fica mais sensível às respostas da terapeuta. $\mathrm{O}$ tempo maior de exposição à FAP na Fase B pode explicar a tendência de subida da 
porcentagem de CRB2 no caso de Rodolfo no decorrer desta fase, com 37,11\% na última sessão dessa fase, o que também ocorre com Walter, mas em uma porcentagem abaixo, com $24,11 \%$ na última sessão da mesma fase.

As quedas das porcentagens de CRB2 durante a Fase B para Rodolfo e Walter dizem respeito a eventos específicos das determinadas sessões. Na sessão 24 para Rodolfo, a terapeuta havia relatado ao cliente que quando ele falava de maneira mais direta e clara, ela conseguia compreender melhor o que ele estava sentindo e pensando (em contrapartida ao relato enrolado e verborrágico de Rodolfo para se esquivar quando falava sobre assuntos de relacionamentos e família). Assim, na sessão 25, o cliente retomou este tema e disse ter pensando bastante, mas que se sentiu culpado por talvez não estar sendo direito e claro durante toda a terapia. Isso resultou na queda de CRB2, porém a porcentagem de CRB1 abaixou. Da mesma maneira, a porcentagem de CRB2 também caiu para Walter na sessão 33, devido ao tema da sessão ter sido voltado para o vestibular. Walter estava feliz que havia passado para a segunda fase da FUVEST, porém relatou bastante incômodo quando as pessoas o parabenizavam, julgando como algo "apenas para massagear o seu ego". A sessão tratou sobre a questão dos rótulos e do autocuidado em valorizar as conquistas e o cliente verbalizou pouco. Ainda assim, a porcentagem de CRB1 continuou caindo. No caso de Murilo, entre a primeira sessão da Fase B e a sessão 28, percebemos uma queda na porcentagem de CRB2 e CRB1. Entre essas sessões, o cliente teve três episódios de crise de ansiedade, tendo as sessões de terapia sido focadas em manejar esse cenário, podendo explicar a queda de CRB2. Após a melhora do cliente, percebe-se a tendência de aumento das porcentagens de CRB2 e manutenção das porcentagens de CRB1 até o final da fase.

Quando consideramos a mudança da Fase B para a sessão de seguimento, observamos que há uma queda na porcentagem de CRB2 no caso de Rodolfo, de 37,1\% 
na última sessão da Fase B, para 35,32\% na sessão de seguimento. Em relação ao CRB1, houve um aumento na porcentagem entre essas duas sessões, de 6,94\% na última sessão da Fase B, para 14,07\% na sessão de seguimento. Esse dado revela que a exposição de maior tempo à FAP, após um mês de intervalo entre o fim da Fase $\mathrm{B}$ e a sessão de seguimento, provoca maior interferência nos níveis de CRB1 e CRB2, uma vez que, no caso de Rodolfo, de acordo com a conceituação de caso, a dificuldade no estabelecimento de vínculos interpessoais era intensa e o vínculo terapêutico estabelecido durante todo o processo foi fundamental para modificar tal comportamento. Porém, a pausa de um mês no processo terapêutico, sem qualquer tipo de terapia ou intervenção, para cumprir os requisitos de uma sessão de seguimento, interferiu na queda da porcentagem de CRB2 de Rodolfo, apresentando um distanciamento da terapeuta, o que não aconteceu nos outros casos. No caso de Walter, houve pouca diferença entre as porcentagens de CRB2 ao final da Fase B e sessão de seguimento, de $24,11 \%$ para $24,5 \%$, enquanto a porcentagem de CRB1 subiu de 5,92\% para 13,5\%. Para Murilo, houve queda na porcentagem de CRB2 entre a última sessão da Fase B e a sessão de seguimento, de 27,85\% para 21,20\%, enquanto a porcentagem de CRB1 manteve tendência de queda, abaixando de 3,28\% na última sessão da Fase B para 1,57\% na sessão de seguimento.

Ainda assim, ao compararmos as diferenças entre as porcentagens de CRB1 e CRB2 na sessão de seguimento entre cada participante, percebemos a maior diferença no caso de Rodolfo, com 21,25\% entre CRB2 e CRB1. Para Walter, essa diferença foi de $11 \%$ e, para Murilo, de 19,63\%. Novamente a questão do tempo de exposição à FAP interferiu tanto na diferença entre as porcentagens de CRB2 e CRB1 ao final da Fase B, quanto na estabilidade da manutenção do CRB2, bem como as características individuais de cada caso. Outro dado importante é que na sessão de seguimento, tanto para Rodolfo quanto para Walter, a porcentagem de CRB1 subiu, de 6,64\% para $14,07 \%$ no caso de 
Rodolfo e de 5,92\% para 13,5\% no caso de Walter. Esse aumento pode ser explicado pelo intervalo de um mês entre a última sessão da Fase B e a sessão de seguimento, sem terapia e qualquer tipo de intervenção, revelando a importância do vínculo interpessoal para indivíduos com ansiedade social e como a ruptura do contato pode aumentar a frequência dos CRB1s responsáveis pela esquiva de intimidade. Além disso, uma vez sinalizados que a sessão de seguimento seria a última sessão da pesquisa, os clientes se comportaram de maneira a esquivar-se do contato com o terapeuta, com relato menos descritivo e apontando ainda dificuldades, especialmente no caso de Rodolfo. Para Walter, o diferencial da sessão de seguimento foi que, um dia antes, ele havia recebido a notícia de que havia passado no vestibular da USP-SP, em medicina, e estava bastante empolgado. Apesar disso, esse evento fez com que ele entrasse em contato com novas experiências e conhecesse novas pessoas, evidenciando seus CRB1s de esquiva de intimidade em sessão. No caso de Murilo, a porcentagem de CRB1 caiu de 3,28\% para 1,57\%, revelando, novamente, a característica específica deste caso e o bom manejo terapêutico da pesquisadora.

Uma análise bastante importante e que será descrita a seguir, é a relação entre os CRBs descritos na conceituação de caso e os números encontrados no FAPRS. No caso de Rodolfo, de acordo com a conceituação de caso, os CRB1s (comportamento clinicamente relevante do tipo problema) foram divididos em CRB1-A, indicando esquiva de conflito, e CRB1-B, indicando esquiva de intimidade, ambos com a função de evitar avaliação e julgamento por parte do terapeuta. Dessa maneira, o CRB2-A se caracterizou por um comportamento do cliente em expor sua opinião, ainda que contrária à do terapeuta, e relatar quando não quisesse falar de algum assunto, e o CRB2-B se caracterizou pela expressão de sentimentos e pensamentos de maneira mais descritiva ao terapeuta. Ao longo da Fase A do experimento, podemos perceber a alta porcentagem de 
CRB1 no caso de Rodolfo, especialmente por ele apresentar dificuldades em expressar o que sentia e pensava, especialmente em relação à família e a relacionamentos, com medo de uma avaliação negativa do terapeuta acerca de sua conduta enquanto um filho que não desse valor aos pais e um rapaz de 36 anos que ainda não havia tido um relacionamento amoroso. Tal comportamento fazia com que Rodolfo invalidasse seus sentimentos e opiniões acerca dos fatos, e desviasse dos assuntos quando questionado pela terapeuta. Quanto ao CRB2 durante a Fase A, percebemos um aumento entre as sessões 1 e 6, seguido de uma queda significativa entre as sessões 6 e 7. Isto se deve, pois logo após as primeiras sessões desta fase, Rodolfo relatou bastante incômodo em relação ao gravador (CRB2), e que talvez tivesse apresentado um relato exagerado sobre o que pensava dos pais e de relacionamentos (CRB1) e isso teria feito com que ele se expresse mal (CRB1). A partir da primeira sessão da Fase B, com a introdução da FAP, percebemos um aumento significativo da porcentagem de CRB2, com o cliente tendo sido reforçado a validar seus sentimentos e pensamentos e descrever de maneira mais objetiva o que dissesse em sessão, sem tantas "voltas". Em contrapartida, a porcentagem de CRB1 apresentou forte queda desde o início da Fase B, com a terapeuta consequenciando os comportamentos de invalidação de sentimentos e pensamentos e as falas longas e confusas do cliente.

Ao longo de todo o processo terapêutico, foi possível destacar alguns comportamentos de melhora fora de sessão $(\mathrm{O} 2)$. Conforme descrito na conceituação de caso do cliente, Rodolfo foi empregado através de um concurso público. Isso fez com que ele entrasse em exposição a novas relações no trabalho e relatasse estar conseguindo ser mais assertivo em relação a suas vontades, pedidos e opiniões para os colegas de trabalho. Durante o período, o cliente reclamava bastante da postura dos colegas de trabalho (falavam alto na biblioteca e reclamavam do trabalho) e, com o tempo, compreendeu que seu receio era de as pessoas achassem que ele também reclamava e falava mal do trabalho. 
Outro ponto importante levantado durante a conceituação, era a relação de Rodolfo com sua mãe, que não deixava o filho fazer sua comida, e isso prejudicava a alimentação que o cliente queria manter devido aos exercícios físicos. Na sessão de seguimento, Rodolfo relatou que conseguiu dizer à mãe que gostaria de ter uma alimentação diferente e que isso implicaria na necessidade dele em cozinhar. A mãe compreendeu, mas pediu para que ele dissesse o que queria comer e ela faria as refeições. De qualquer maneira, Rodolfo conseguiu expressar de maneira objetiva à mãe as suas vontades, apesar do medo do conflito. Na sessão de seguimento, podemos notar que a porcentagem de CRB2 teve uma leve queda, e a de CRB1 teve um aumento significativo. Nesta sessão, a terapeuta sentiu um afastamento e certa apatia do cliente no início, que falou de maneira vaga sobre os assuntos. No decorrer da sessão, ficou mais próximo da terapeuta e contou ter pensando sobre a terapia no tempo em que ficamos sem nos ver.

No caso de Walter, de acordo com a conceituação de caso, seu CRB1 também se dividiu em duas classes, e o CRB1-A também se caracterizava por esquiva de intimidade, através de falas verborrágicas e um repertório verbal bastante rebuscado, especialmente diante de temas como medicina, política, comportamentos, com a função de evitar julgamentos e avaliações acerca de sua inteligência. Quando o tema era sobre sentimentos e emoções, o cliente falava pouco e de maneira racional. O CRB2-A, neste caso, seria um repertório verbal mais simples e descritivo, no que diz respeito às suas emoções. Ao longo da Fase A, podemos perceber a tendência de queda nas porcentagens de CRB1 e aumento nas porcentagens de CRB2. Entre as sessões 11 e 12, nota-se um aumento nas duas porcentagens, devido ao evento da quebra dos esmaltes de Walter por seu pai. Aqui, o cliente validou seus sentimentos e relatou estar bastante chateado e com raiva de seu pai, evidenciado pelo aumento na porcentagem de CRB2, porém, justificou as atitudes do pai, alegando que este "não tinha muito jeito de conversar" e "não fazia por mal", 
evidenciando o aumento da porcentagem de CRB1, neste mesmo momento. Após a introdução da FAP, na sessão B, com o decorrer da fase, quando o cliente passou a falar de maneira mais simples e descritiva e a validar os seus sentimentos, uma outra classe de CRB1 apareceu, classificada na conceituação de caso como CRB1-B, a qual se caracteriza pelo relato dicotômico entre o que ele considerava fútil e intelectual, e tal comportamento prejudicava seu contato com autocuidado, escolhas de universidades, demonstração de sentimentos, gerando um afastamento da terapeuta e das pessoas à sua volta. Durante esta fase, Walter passou a validar mais suas vontade e emoções, sem classificá-las em fúteis ou úteis. Assim, relatou que não cuidava tanto assim da sua aparência por achar algo fútil, mas reconheceu que isso o faria sentir-se melhor. Da mesma maneira, contou que percebeu que sua vontade de estudar na USP-SP estava atrelada ao status da universidade, e que ficou feliz quando passou na UNIFESP. Na sessão de seguimento, Walter descreveu alguns comportamentos de melhora fora de sessão $(\mathrm{O} 2)$, na qual apareceu fisicamente diferente (havia cortado o cabelo, tirado a barba e vestia roupas mais novas) e bastante empolgado, devido ao resultado do vestibular. Além disso, relatou que conseguiu dizer a mãe que ficou muito chateado com uma fala dela e que não a desculparia dessa vez. No final da sessão, disse que não tinha se lembrado que seria a última sessão, mas que agradecia muito por todo o trabalho e ajuda e que a terapia foi muito importante para ele (validação e demonstração de sentimentos para a terapeuta). Esta foi a primeira vez que Walter falou sobre a importância da terapia e agradeceu diretamente à terapeuta.

Para Murilo, a conceituação de caso estabeleceu como CRB1 a esquiva de intimidade, quando diante de solicitação de relato sobre si mesmo, o cliente emitia respostas pouco descritivas e bastante genéricas. Como CRB2, portanto, foram esperadas respostas verbais mais descritivas acerca de sentimentos e emoções. Durante as primeiras sessões da Fase A, a terapeuta teve bastante dificuldade em estabelecer os CRBs, dado 
que o cliente falava de maneira muito genérica e metafórica. Isso fez com que a terapeuta tivesse que evocar mais respostas do cliente, a fim de definir melhor os seus comportamentos problemas. Ao longo da Fase A, portanto, notamos uma constância na porcentagem de CRB2, e queda significativa na porcentagem de CRB1, que está associada à importância do vínculo estabelecido entre terapeuta e cliente, dado que este não possuía outras relações interpessoais que não as familiares e de um único amigo. Além disso, na tentativa de identificar os CRBs, além da evocação, a terapeuta precisou validar alguns comportamentos do cliente diante de situações relatadas por ele, visando a ética do processo terapêutico, o que resultou também na queda da porcentagem de CRB1, uma vez que as respostas de autojulgamento, avaliações negativas e depreciação eram constantes por parte de Murilo. Após a introdução da FAP, na Fase B, já é possível perceber um aumento na porcentagem de CRB2 e queda na de CRB1, com o cliente descrevendo com maior clareza o que estava sentindo e pensando, diminuindo o controle externo sobre sua imagem. Respostas de autojulgamento, avaliações negativas e depreciação a respeito de si mesmo também diminuíram, o que resultou em uma maior exposição de Murilo a situações sociais e comportamentos de melhora fora de sessão (O2), como entrevistas de emprego, engajamento em trabalhos autônomos (freela de ilustração de um livro, através de uma amiga que conheceu pela internet), retorno aos ensaios da banda com colegas e maior socialização com os parentes. Como já mencionado, entre as sessões 21 e 28, Murilo passou por alguns episódios de ansiedade, o que mudou o foco da terapia, visando o manejo da situação. Neste momento, podemos perceber a tendência de queda na porcentagem de CRB2. Porém, com a melhora de seus comportamentos de discriminação acerca do que sentia e dos possíveis gatilhos de sua ansiedade, a partir da sessão 28 já há um aumento na porcentagem de CRB2. Na sessão de seguimento, Murilo mantém a tendência de queda da porcentagem de CRB1, e 
descreve de maneira mais detalhada os últimos acontecimentos, seus pensamentos e sentimentos, além de melhoras extra sessão, revelando a manutenção do CRB2, apesar da queda da porcentagem entre a última sessão da Fase B para a sessão de seguimento (de $27,85 \%$ para $21,20 \%$, respectivamente), e que pode ser explicada pelo tempo de intervalo dado no processo terapêutico. Além disso, Murilo relatou ter voltado à desenhar e a sair de casa para visitar os amigos e familiares, atividades que tinham sido interrompidas após os episódios de crise de ansiedade. Ainda, o cliente conseguiu descrever-se de maneira bastante detalhada, além de relatar a diminuição de pensamentos excessivos de autojulgamento e avaliação a respeito de si mesmo, e maior engajamento em atividades fora de casa, percebendo que, apesar de muitas vezes sem vontade, quando saía, sentiase mais animado.

Alguns comportamentos de melhora fora de sessão (O2), descritos na conceituação de caso, não apareceram em dois dos três participantes. No caso de Rodolfo, a exposição a situações sociais em que ele pudesse demonstrar interesse ou ser receptivo ao interesse de alguém, não ocorreu, além da dificuldade em falar sobre relacionamentos amorosos com a família e amigos. Este assunto era o que mais causava esquiva para Rodolfo, porém, em sessão, ele demonstrou engajamento ao manter assuntos sobre relacionamentos amoroso e descrever como se sentia. Quanto à Walter, ainda descreveu dificuldade em falar sobre seus estudos e estilo de vida para amigos e parentes e em manter conversas com pessoas que não dominam o assunto falado. Porém, um avanço importante foi conseguir dizer à mãe que algumas falas dela o machucavam e que ele estava muito triste. Em relação ao Murilo, todos os $\mathrm{O} 2 \mathrm{~s}$ esperados apareceram no relato do cliente, tendo conseguido se aproximar mais de amigos ou desconhecidos, pois seu comportamento de autojulgamento diminuiu bastante. Além disso, relatou conseguir dizer ao amigo quando estivesse desconfortável com algo ou quando não soubesse muito 
sobre algum assunto. Por final, Murilo reduziu significativamente os comportamentos de autojulgamento e depreciação de si mesmo, facilitando sua aproximação com os outros.

De maneira geral, ao relacionarmos os comportamentos típicos de indivíduos com ansiedade social, os quais tem função de esquiva de situações que possam causar avaliações negativas e julgamentos, com a conceituação de caso estabelecida para os três participantes, percebemos que todos passaram a se esquivar menos das situações que lhes eram aversivas e a se engajar mais em situação sociais, uma vez que os comportamentos de avaliação e julgamento excessivos sobre si mesmo diminuíram. Além disso, os comportamentos de culpa, presentes nos três clientes, também diminuíram significativamente, especialmente com as respostas de validação de sentimentos feitas pela terapeuta, auxiliando na maior exposição a estímulos fora de sessão.

A seguir, as Figuras 7 apresenta os resultados obtidos pelo FAPRS no que diz respeito aos comportamentos do terapeuta, representados pela porcentagem de Regra 2 (evocar comportamentos clinicamente relevantes), Regra 3-1 (responder contingente ao CRB1) e Regra 3-2 (responder contingente ao CRB2) ao longo das fases do experimento. Da mesma maneira que ocorre com as porcentagens de CRB1 e CRB2 ao longo do processo, a Regra 3-1 deve diminuir com a introdução da FAP, e a Regra 3-2 aumentar. Isto ocorre, pois a Regra 3-1 responde contingente ao CRB1 e, se na Fase A a porcentagem de CRB1 é superior à da Fase B (devido à conceituação de caso e às regras de categorização do FAPRS, dado que a extinção é também interpretada como responder contingente do terapeuta ao CRB1), a porcentagem da Regra 3-1 também será superior à da Regra 3-2, a qual responde contingente ao CRB2 e, portanto, deverá ser superior na Fase B, uma vez que a porcentagem de CRB2 é superior nesta fase do experimento. Esses dados também foram encontrados dos trabalhos de Aranha (2017), Fernanda (2018), Lima (2017), Mangabeira (2014), Oshiro (2011), Vartanian (2017) e Villas-Bôas (2015). 


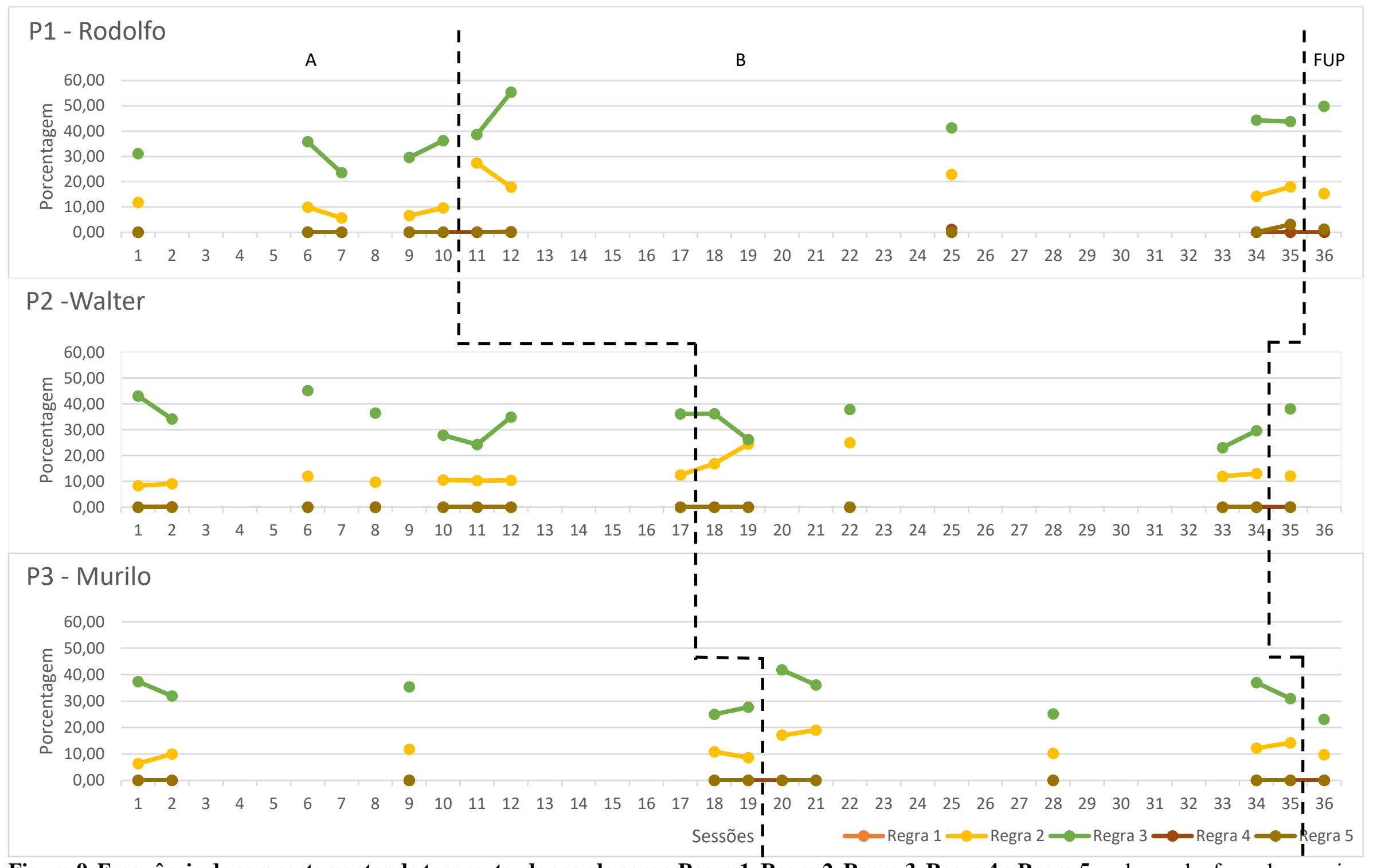

Figura 9. Frequência de comportamentos do terapeuta, de acordo com a Regra 1, Regra 2, Regra 3, Regra 4 e Regra 5, ao longo das fases do experimento, por participante: (1) Rodolfo, (2) Walter e (3) Murilo. Legenda: A= linha de base; B = FAP e FUP = seguimento. A linha preta tracejada indica mudança de fase. 
A porcentagem de Regra 1 permaneceu nula em todo o delineamento experimental, uma vez que esta regra se refere a um comportamento encoberto do terapeuta e, portanto, de difícil categorização pelo instrumento. A Regra 2 oscilou entre as fases, sempre superior na Fase B. As Regras 3-1 foi superior a todas as regras durante a Fase A, com aumento até a Fase B no caso de Rodolfo e declínio nos casos de Walter e Murilo. Após o início da Fase B, a Regra 3-1 caiu de porcentagem e a Regra 3-2 aumentou substancialmente em todos os participantes. As Regras 1, 4 e 5 apresentaram índices baixos ou nulos e este dado também foi observado em outros estudos com o uso da FAP em delineamento de caso único (Aranha, 2017; Lima; 2017; Villas-Bôas, 2015; e Vartanian, 2017). Isto ocorre, provavelmente, porque tais regras representam respostas encobertas do terapeuta e tais respostas não podem ser identificadas por parte dos categorizadores no uso do instrumento FAPRS e, por isso, acabam não sendo identificadas.

Neste sentido, como apontado também em Lima (2017), a falta de categorias pode refletir em uma lacuna no instrumento FAPRS e em seu critério de hierarquia, a qual não identifica outras funções dos comportamentos do cliente e do terapeuta. Novas pesquisas que tenham como intuito inserir outras categorias ou modificar os critérios de hierarquia podem apresentar melhor os mecanismos e processos de mudança que ocorrem na FAP.

A Figura 8 apresenta os dados dos CRB1 e CRB2 em conjunto com as Regras 2 e Regras 3-1 e Regras 3-2, nas fases A e B do delineamento, para os três participantes. 


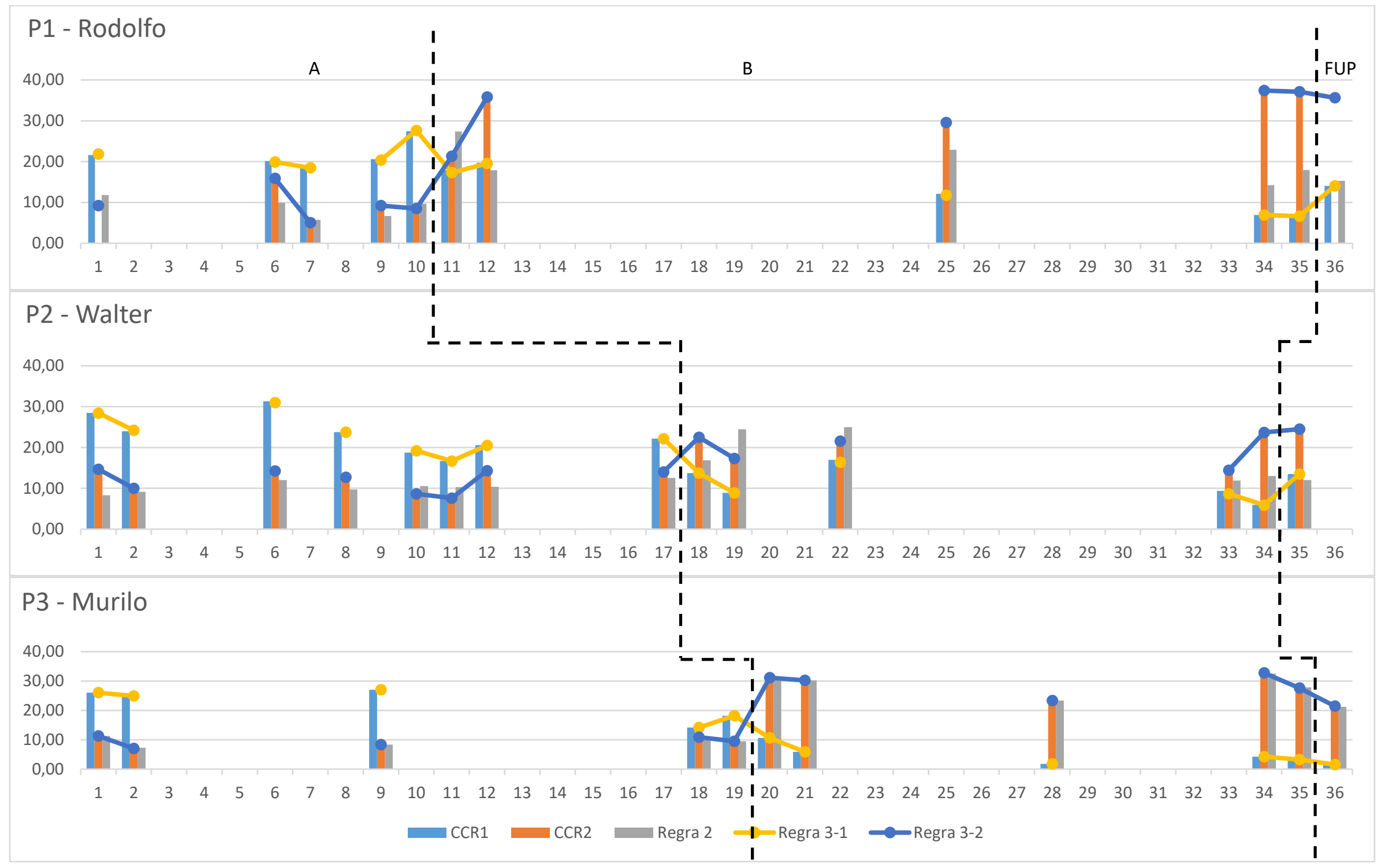

Figura 10. Frequência de comportamentos do terapeuta, de acordo com a Regra 2, Regra 3-1 e 3-2 relacionadas aos CRB1 e CRB2 ao longo das fases do experimento, por participante: (1) Rodolfo, (2) Walter e (3) Murilo. Legenda: A= linha de base; B = FAP e FUP = seguimento. A linha preta tracejada indica mudança de fase. 
Conforme podemos observar no gráfico do três participantes, a porcentagem de Regra 2 na Fase A é baixa, sendo inferior às porcentagens de Regra 3 nos participantes Rodolfo e Walter, com alguns momentos de equivalência, mas superior em grande parte da Fase A (entre as sessões 2 e 18) no caso de Murilo, com porcentagem de $10 \%$ na sessão $2,11,8 \%$ na sessão 9 e 10,85\% na sessão 18 , em contrapartida às porcentagens de Regra 3-1 nas mesmas sessões $(24,87 \%, 27,01 \%$ e 14,14 , respectivamente) e de Regra 3$2(7,07 \%, 8,38 \%$ e 10,85\%). O excesso de Regra 2 na Fase A do experimento, antes da introdução da FAP, pode ser explicado devido ao relato pouco descritivo e genérico de Murilo, fazendo-se necessário o aumento de perguntas por parte da terapeuta no intuito de melhor compreender o caso e, de acordo com a conceituação de caso, tais perguntas pertenceriam à categoria de Regra 2.

Da mesma maneira que ocorreu com os CRBs, na Fase A do experimento, a Regra 3-1 foi superior para os três participantes, com porcentagens de $21,84 \%$ na primeira sessão da Fase A para Rodolfo, 28,44\% para Walter e 26,04\% para Murilo. Tais porcentagens seguem as proporções de porcentagens dos CRB1s dos participantes, com Walter tendo a maior porcentagem na primeira sessão da Fase A, bem como ocorreu com a Regra 3-1, portanto. Na última sessão da Fase A, a porcentagem de Regra 3-1 atingiu seu máximo no caso de Rodolfo, com 27,64\%, 22,14\% para Walter e 18,15\% para Murilo, sempre acima das porcentagens de Regra 3-2.

Após a introdução da FAP, no início da Fase B, podemos observar uma reversão brusca entre as porcentagens de Regra 3-1 e Regra 3-2, em todos os participantes. Entre a última sessão da Fase A e a primeira sessão da Fase B, pós introdução da FAP, houve um aumento na porcentagem de Regra 3-2 de 8,52\% para 21,32\% em Rodolfo, $14,02 \%$ para $21,55 \%$ em Walter e 9,52\% para 31,12\% para Murilo. Em conjunto ao aumento da porcentagem da Regra 3-2 após a introdução da FAP, também houve o leve aumento da 
Regra 2, em todos os clientes. Esse dado revela o poder evocativo da Regra 3-2 na Fase $\mathrm{B}$, dado que a literatura revela que o mecanismo de mudança clínica está no responder contingente do terapeuta aos CRBs, inclusive ao CRB2 (Busch et al., 2010, Kanter et al., 2006; Kohlenberg et al., 1999; Kohlenberg \& Tsai et al., 2001). Porém, é importante destacar, como analisado por Vartanian (2017) e observado em outros estudos (Aranha, no prelo; Moreira, 2018; Lima; 2017; Mangabeira, 2014, Oshiro, 2011 e Villas-Bôas, 2015) que, em muitas vezes, a Regra 3-2 como reforçadora do CRB2 também apresentava função de evocar, Regra 2 e, devido à hierarquia de categorização apresentada pelo FAPRS, era categorizada como Regra 3-2 ao invés de Regra 2. Este dado explica o aumento brusco da porcentagem de Regra 3-2, em contraposição ao aumento menos intenso da porcentagem de Regra 2.

A análise dos resultados do comportamento da terapeuta em relação às Regras 2 , Regra 3-1 e Regra 3-2, revelam o poder evocativo da Regra 3-2 na Fase B. De acordo com a literatura, o mecanismo de mudança clínica encontra-se no responder contingente do terapeuta aos comportamentos clinicamente relevantes do cliente, fundamentalmente nos CRB2 (Busch et al., 2010; Busch et al., 2009; Kanter et al., 2006; Kohlenberg et al., 1999; Kohlenberg \& Tsai, 1991). Assim, o aumento da Regra 2 logo após a introdução da FAP e o aumento significativo da Regra 3-2 e CRB2 corroboram ainda mais para essa discussão.

Conforme apontado em Lima (2017) e Vartanian (2017), a consequenciação do CRB2, muitas vezes, apresentava a função de evocar (Regra 2) e, por conta da hierarquia de categorização do FAPRS, era categorizado como Regra 3-2, ao invés de Regra 2. Esse está refletido no leve aumento da porcentagem da Regra 2 após a introdução da FAP, dados também encontrados em Aranha (no prelo), Busch et al. (2009), Mangabeira (2014), Oshiro et al. (2012) e Villas-Bôas (2015). 


\section{Conclusão}

A psicoterapia Analítica Funcional (FAP) tem sido bastante utilizada em estudos para diferentes transtornos, especialmente aos que se relacionam com o comprometimento interpessoal, apontando melhoras significativas na qualidade de vida e das relações interpessoais dos clientes. Porém, até o momento da finalização deste estudo, a literatura não apresentava pesquisas experimentais em prática clínica que avaliassem o uso da FAP no Transtorno de Ansiedade Social (TAS), mas sim com outros transtornos de ansiedade. Considerando este transtorno como um quadro clínico de grande prevalência na sociedade e que acarreta grandes prejuízos funcionais e comprometimentos interpessoais, o presente estudo teve como objetivo verificar a eficácia da FAP enquanto tratamento para indivíduos com ansiedade social e analisar os processos de mudança clínica utilizados na FAP. Além disso, buscou-se mostrar a generalidade desta psicoterapia em diferentes populações, replicando os dados de Oshiro (2011), Oshiro, Kanter e Meyer (2011); Aranha, no prelo; Moreira, 2018; Lima; 2017; Vartanian (2017).

Para isso, a decisão metodológica se deu pelo delineamento experimental de caso único em linha de base múltipla (LBM), com a introdução da variável independente (FAP) em momentos distintos para cada um dos três clientes da pesquisa, diagnosticados com ansiedade social. A escolha desse delineamento foi de suma importância, uma vez que este procedimento permite a análise das mudanças comportamentais do sujeito em comparação consigo mesmo, ou seja, o sujeito como seu próprio controle, ao longo do tempo. Além disso, a linha de base múltipla foi escolhida por uma questão ética, uma vez que, para esse tipo de população, a retirada da intervenção seria bastante danosa aos clientes, afetando a relação terapêutica, dado que o estabelecimento de relacionamentos 
interpessoais é um repertório muito difícil para este tipo de população. Além disso, a LBM proporciona ao pesquisador a possibilidade de maior controle do tempo de linha base, das variáveis dependentes e da introdução da variável independente.

O número total de sessões para cada participante foi de 36 para o primeiro participante, sendo 10 sessões na Fase A, 25 na Fase B (FAP) e uma sessão de seguimento; 35 para o segundo participante, sendo 17 na Fase A, 17 na Fase B (FAP) e uma sessão de seguimento; e 36 para o terceiro participante, sendo 19 na Fase A, 16 na Fase B (FAP) e uma sessão de seguimento.

Nos três clientes foram observados padrões de comportamentos típicos de indivíduos com ansiedade social, com esquiva de situações que pudessem gerar algum tipo de julgamento ou avalições negativas a respeito de seus comportamentos. Assim, os clientes se esquivavam de quaisquer relações que os deixassem vulneráveis, ou seja, relações de intimidade e vulnerabilidade que pudessem gerar avaliações ou julgamentos. Por ser um padrão comum desse tipo de transtorno, os clientes apresentavam bastante dificuldade em criar novos vínculos e esse cenário apareceu com a pesquisadoraterapeuta, possibilitando o aparecimento das dificuldades de cada participante durante as sessões de terapia.

Ao total, foram coletadas 107 sessões de psicoterapia. Destas, 35 foram analisadas, totalizando 24.598 unidades de análises, entre falas do terapeuta e do cliente. Para a análise destas falas, as sessões foram transcritas e categorizadas, por meio do instrumento FAPRS, e outros instrumentos de medida de resultados foram selecionados (OQ-45, LSAS, SPIN e BDI), além do cálculo de concordância entre aferidores.

O presente estudo tem como pontos fortes o pioneirismo em explorar o tratamento da ansiedade social com a FAP, e por isso a importância de se realizar um estudo de caso 
único inicial com esse tema. A primeira grande contribuição deste trabalho diz respeito aos resultados expressivos em relação ao FAPRS, nos quais a introdução da FAP (variável independente) produziu o aumento significativo dos comportamentos de melhora (CRB2) e diminuição dos comportamentos problema (CRB1), podendo ser percebidos logo na primeira sessão após a introdução da FAP, para todos os participantes. Na sessão de seguimento, para todos os participantes, as porcentagens de CRB2 mantiveram-se acima das porcentagens de CRB1, demonstrando que os resultados alcançados durante o processo terapêutico foram consolidados, mantendo-se mesmo após um mês de pausa sem qualquer tipo de intervenção. Estes resultados vão de acordo com a literatura, a qual aponta que o principal mecanismo de mudança clínica na FAP está relacionado à modelagem dos comportamentos em sessão, em especial aos comportamentos de melhora (Aranha, 2017; Busch et al., 2009; Lima, 2017; Kohlenberg et al., 1999; Kohlenberg \& Tsai, 1911; Oshiro, 2011; Vartanian, 2017; Villas-Bôas, 2015).

Conforme apontado por Oshiro (2011) e Villas-Bôas (2015), faz-se necessário o uso de medidas de resultados externos à sessão, com o intuito de aumentar o controle dos resultados encontrados na utilização da FAP. Assim, considerando tal apontamento, o presente estudo fez uso de outros instrumentos para medir os resultados externos à sessão, como o OQ-45, LSAS, SPIN e BDI. Os resultados dos instrumentos não apresentaram mudança significativa quanto ao uso da FAP, tendo pouca variação em comparação aos dados da Fase A e da Fase B. O instrumento BDI foi o que mais apresentou variação, em especial ao participante Murilo, uma vez que este começou a psicoterapia com um grau moderado para a depressão e na sessão de seguimento, atingiu a menor pontuação, tendo classificação de grau mínimo para a depressão. Estes dados, porém, se relacionam mais diretamente com a qualidade da psicoterapia e da relação terapêutica estabelecidas com a terapeuta. 
Outra contribuição bastante relevante do presente estudo foi o controle metodológico e o sucesso do delineamento experimental em linha de base múltipla, apontados Kratochwill et al. (2013), e alcançado com êxito também no trabalho de Lima (2017). Porém, a literatura não aponta outras pesquisas de prática clínica que tenham obtido tais alcances com a linha de base múltipla, mas apenas com estudo de reversão (Geremias, 2015; Mangabeira, 2014; Oshiro, 2011; Vartanian, 2017; Villas-bôas, 2015) e do tipo AB (Aranha, 2017; Fonseca, 2016). A possibilidade de maior controle de variáveis com a LBM, permitiu, no presente trabalho, um bom manejo terapêutico, uma vez que não houve desistências de participantes e estes mantiveram-se assíduos durante todo o processo.

Os critérios de Kratochwill et al. (2013) foram seguidos para garantir a validade do estudo de caso único. Durante a Fase A ocorreu a conceituação de caso, na qual os comportamentos clinicamente relevantes foram selecionados como variáveis dependentes do estudo. Após a estabilidade dos dados, deu-se início à Fase B, com a introdução da variável independente, FAP. Após o término da coleta, e um período de um mês sem a psicoterapia, foi realizada uma sessão de seguimento para mensurar, novamente, as variáveis dependentes do cliente, a fim de verificar a manutenção ou não dos resultados finais.

As fragilidades do estudo referem-se à aferição de concordância, na qual o índice Kappa ficou abaixo do índice esperado, de 0.6. Apesar desse dado, os índices Kappa alcançados foram considerados de concordância razoável e moderada, de acordo com Landis e Koch (1977), e a concordância percentual atingiu o valor mínimo esperado, de $80 \%$, ou mais, para três das seis sessões aferidas. Este dado revela que, apesar dos resultados insatisfatórios quanto ao índice Kappa, o treino médio junto da conceituação 
de caso e do estudo os instrumentos, possibilitou, na média, bons resultados de concordância.

Ainda em relação à aferição de concordância, o fato da pesquisadora-terapeuta ser a principal aferidora interna da pesquisa, pode ser levantado como uma fragilidade. Apesar disto, estudos como o de Geremias (2014) e de Oshiro (2011) revelam que não houve diferenças nos resultados dos processos terapêuticos em pesquisas quando a pesquisadora era a aferidora principal, mas não era a terapeuta. Um contraponto é que a pesquisadora-terapeuta enquanto aferidora principal tem acesso a outros dados importantes do processo, e seguindo os critérios necessários para garantir a validade do estudo, de acordo com Kratochwill et al. (2013), diminui o nível de fragilidade da pesquisadora ser a terapeuta e, portanto, deste possível viés.

Apesar de tais limitações apresentadas, o presente estudo classifica-se como um estudo do tipo III (Kazdin, 1982), devido ao seu grau de validade interna, aos múltiplos casos e às mudanças produzidas nos clientes. Mesmo que os instrumentos de medidas externas não tenham apresentado grandes resultados no que diz respeito aos efeitos de mudança nos comportamentos dos clientes, como ocorreu com o FAPRS, as conclusões do efeito da FAP na intervenção de indivíduos com ansiedade social e a generalização dos dados obtidos não perdem sua validade (Kazdin, 1982).

De modo geral, a análise dos dados permite concluir que os resultados da FAP com os clientes foram bastante satisfatórios, e recomenda-se estudos mais complexos com essa população, afim de verificar a generalidade da FAP enquanto tratamento para indivíduos com ansiedade social. Para os possíveis estudos futuros, sugere-se maior controle quanto à aferição de concordância e seleção de instrumentos de medidas externas mais precisos. 


\section{REFERÊNCIAS}

Amorim, P. (1998). Le Processus Diagnostique des Troubles Psychotiques. Approche Standardisée et Approche Clinique [dissertation]. Paris (France): Université de Paris VI.

Andrade, L., Viana, M. C., \& Silveira, C. M. (2006). Epidemiologia dos transtornos psiquiátricos na mulher. Rev. Psiquiatr. Clínica, 33 (2), p. 43-54.

Associação Psiquiátrica Americana. (2013). Manual Diagnóstico e Estatístico de

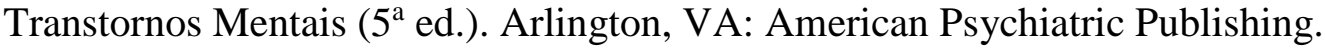

APA (2014). DSM-V: Manual Diagnóstico e Estatístico de Transtornos Mentais. Porto Alegre: Artmed.

Aranha, A. S. (2017). A Psicoterapia Analítica Funcional aplicada ao Transtorno por Uso de Substâncias. Dissertação de mestrado, Universidade de São Paulo, São Paulo, SP, Brasil.

Aranha, A. S.; Oshiro, C. K. B. (no prelo). Contribuições da Psicoterapia Analítica Funcional (FAP) no tratamento do Transtorno por Uso de Substâncias (TUS). Acta Comportamentalia.

Argyle, M., Bryant, B. M., \& Trower, P. (1974). Social skills training and psychoterapy: A comparative study. Psychological Medicine, 4(2), p. 435-443.

Associação Brasileira de Psiquiatria [ABP] (2011). Transtorno da Ansiedade Social:Diagnóstico. In: Diretrizes Clínicas na Saúde Suplementar. Associação Médica Brasileira e Agência Nacional de Saúde Suplementar. http://www.projetodiretrizes.org.br/ans/diretrizes/transtorno_da_ansiedade_sociedade_s ocial-diagnostico.pdf

Assumpção JR, F. B. (2009). Psicopatologia: aspectos clínicos. Rio de Janeiro: Guanabara Koogan.

Banaco, R. A. (2001). Alternativas não-aversivas para tratamento de problemas de ansiedade. Em: M. L. Marinho e V. E. Caballo (org.). Psicologia Clínica e da Saúde. Londrina: Atualidade Acadêmica.

Barbosa, C. (2004). Ansiedade: Possíveis intervenções na análise do comportamento. In: Brandão, M.; Conte, F., Brandão, F., Ingberman, Y.; Moura, C.; Silva, V. \& Oliane, S. (Orgs.). Sobre comportamento e cognição: v. 13, p. 163-167.

Barlow, D. H.; Rapee, R. M. \& Brown, T. A. (1992). Behavioral treatment of generalized anxiety disorder. Behavior Therapy, 23, 551-570.

Beck, A. T., Emery, G., \& Greenberg, R. (1985). Anxiety Disorders and Phobias: A Cognitive Perspective. New York: Basic Books Inc. 
Brandão, A. S., Oshiro, C. K. B., \& Pezzato, F. A. (2012). Intervenção baseada na psicoterapia analítica funcional em um caso de transtorno de pânico com agorafobia. Revista Brasileira de Terapia Comportamental e Cognitiva, 14 (1), p. 74-84.

Busch, A. M., Callaghan, G. M., Kanter, J. W., Baruch, D. E., \& Weeks, C. E. (2010). The Functional Analytic Psychotherapy Rating Scale: A replication and extension. Journal of Contemporary Psychotherapy, 40, 11-19. doi: 10.1007/s10879-009-9122-8

Busch, A. M., Kanter, J. M., Callaghan, G. M., Baruch, D. E., Weeks, C. E., \& Berlin, K. S. (2009). A micro-process analysis of Functional Analytic Psychotherapy's mechanism of change. Behavior Therapy, 40, 280-290.

Callaghan, G. M., Summers, C. J., \& Weidman, M. (2003). The treatment of histrionic and narcissistic personality disorder behaviors: A single-subject demonstration od clinical improvement using functional analytic psychotherapy. Journal of Contemporary Psychotherapy,33(4), 321-339.

Callaghan, G. M., \& Follette, W. C. (2008). Coding Manual for the Functional Analytic Psychotherapy Rating Scale (FAPRS).The Behavior Analyst Today, 9, pp. 57-97.

Carvalho, L. F., \& Rocha, G. M. A. (2009). Tradução e adaptação cultural do Outcome Questionnaire (OQ-45) para o Brasil. Psico-USF, 14(3), pp. 309-316.

Castillo, A. R. GL., Recondo, R.; Asbahr, F. R. \& Manfro, G. G. (2000). Transtornos de ansiedade. Revista Brasileira de Psiquiatria, 22. 20-23. Disponíveil em:http://www.scielo.br/pdf/rbp/v22s2/3791.pdf Acesso em: 22 nov. 2017.

Clark, D. M. \& Wells, A. A. (1995). Cognitive model of social phobia. In R. G. Heimberg, M. R. Liebowitz, D. A. Hope \& F. R. Schneider. Social phobia: Diagnosis, assessment and treatment. (pp. 69-93). New York: Guilford.

Coêlho, N. L. (2006). O Conceito de Ansiedade na Análise do Comportamento (Dissertação de Mestrado). Universidade Federal do Pará, Belém. Recuperado de http://repositorio.ufpa.br/jspui/bitstream/2011/1921/1/Dissertacao_ConceitoAnsiedadeA nalise.pdf

Conte, F. C. S. (2008) O uso da psicoterapia analítico funcional (FAP) em grupos terapêuticos. In: Delitti, A. M. C. ; Derdyk, P. R. (Orgs.).. (Org.). Terapia AnalíticoComportamental em Grupo. 1 ed. Santo André: ESETec Editores Associados, 2008, v. 1, p. 127-156.

Cunha, J. A. (2001). Manual da versão em português das Escalas Beck. São Paulo: Casa do Psicólogo.

Curran J. P. (1982). A procedure for the assessment of social skills: The simulated social interaction test. In J. P. Curran. Social skills training: A practical handbook for assessment and treatment (pp. 116-132). New York: Guilford.

D’El Rey, G. J. Fonseca. (2001). Fobia Social: mais do que uma simples timidez. Arq.Ciênc. Saúde Unipar, 5(3): 273-276. 
D'El Rey, Gustavo J. Fonseca, \& Pacini, Carla Alessandra. (2006). Terapia cognitivocomportamental da fobia social: modelos e técnicas. Psicologia em Estudo, 11(2), 269275. https://dx.doi.org/10.1590/S1413-73722006000200005

Estes, W. K., \& Skinner, B. F. (1941). Some quantitative properties of anxiety. Journal of Experimentals Psychology, 29, 390-400.

Falloon, I. R. H., Lindley, P., \& McDonald, R. (1977). Social skills training of out-patient groups: A controlled study with rehearsal and home-work. British Journal of Psychiatric, 131(5), p. 599-609.

Fava, G. A., Grand, S., Rafanelli, C., Conti, S. \& Belluard, P. (2001). Long-term outcome of social phobia treated by exposure. Psychological Medicine, 31(5), 899-905.

Fermoseli, A. F. O., Guimaraes, A. M. V., Silva Neto, A. C., Vilar, A. T. S., Almeida, B. G. C.; \& Albuquerque, C. M. F. (2015). Transtorno de ansiedade: um estudo de prevalência sobre as fobias específicas e a importância da ajuda psicológica. Caderno de Graduação UNIT - Ciências Biológicas e da Saúde, v. 3, p; 115-138.

Follete, W.C.; Naugle, A.E. \& Callaghan, G.M. (1996). A radical behavioral understanding of the therapeutic relationship in effecting change. Behavior Therapy, 27,623-641.

Friman, P. C., Hayes, S. C. \& Wilson, K. G. (1998). Why behavior analysts should study emotion: The example of anxiety. Journal of Applied Behavior Analysis, 31, 137-156.

Gentil, V. (1997). Ansiedade e Transtornos Ansiosos. In: Valentim Gentil, Francisco LotufoNeto e Márcio Antonini Bernik (org.): Pânico, Fobias e Obsessões. São Paulo: Edusp.

Geremias, M. C. G. (2014). Manejo de esquivas emocionais na Psicoterapia Analítica Funcional: delineamento experimental de caso único (Dissertação de Mestrado. Instituto de Psicologia, Universidade de São Paulo, São Paulo). Recuperado de: http://www.teses.usp.br/teses/disponiveis/47/47133/tde-17032015-150030/en.php

Grazziano, E. da S. \& Bianchi, E. R. F. (2004). Nível de Ansiedade de Clientes Submetidos a Cineangiocoronnriografia e de seus Acompanhantes. Rev Latino-am Enfermagem, v.12, n.2, p. 168-74. Disponível em: < http://www. scielo.br/pdf/rlae/v12n2/v12n2a04.pdf> Acesso em: 7 jan. 2018.

Hayes, S. C. (2004). Acceptance and commitment therapy, relational frame theory, and the third wave of behavioral and cognitive therapies. Behavior therapy, 35(4), 639-665.

Heimberg, R. G., Dodge, C. S. \& Hope, D. A. (1990). Cognitive-behavioral treatment of social phobia: Comparison to a credible placebo control. Cognitive Therapy and Research, 14(1), 1-23.

Heimberg, R. G., Juster, H. R., Hope, D. A. \& Mattia, J. I. (1995). Cognitive-behavioral group treatment: Description, case presentation, and empirical support. In M. B. Stein. Social phobia: Clinical and research perspectives. (pp. 293-321). Whashington, DC: American Psychiatric. 
Hessel, A., Borloti, E. B.; \& Haydu, V. B. (2012). O pensar e o sentir numa análise comportamental da ansiedade. Em C. V. B. B. Pessoa, C. E. Costa \& M. F. Benvenuti (Orgs.), Comportamento em foco, vol. 13, p. 283-292.

Hetem, L. A. B. (2004). Diagnóstico diferencial. Em L. A. B. Hetem F. G. Graeff (Orgs.), Transtornos de ansiedade (pp. 191-205). São Paulo, SP: Atheneu.

Ito, L. M., Roso, M. C., Tiwari, S., Kendall, P. C \& Asbahr, F. R. (2008). Terapia cognitivocomportamental da fobia social. Revista Brasileira de Psiquiatria, 30(supl II), 96-101.

Jerremalm, A., Jansson, L. \& Öst, L. G. (1986). Cognitive and physiological reactivity and the effects of diferente behavioral methods in the treatment of social phobia. Behaviour Research and Therapy, 24(2), 171-180.

Kanfer, F.H. \& Phillips, J. S. (1974). Os princípios da aprendizagem na terapia comportamental. São Paulo: EPU.

Kanter, J. W., Landes, S. J., Busch, A. M., Rusch, L. C., Brown, K. R., Barucj, D. E., \& Holman, G. (2006). The effect of contingent reinforcement on target variables in outpatient psychotherapy for depression: A successful and unsuccessful case using functional analytic psychotherapy. Journal of Applied Behavior Analysis, 39, 463-467.

Kazdin, A. E. (1982). Single-case research designs: methods for clinical and applied settings. New York.

Kinrys, G., \& Wygant, L. E. (2005). Transtornos de ansiedade em mulheres: gênero influencia o tratamento. Rev. Bras. Psiquiatr. 27 (Supl. 2), p. 43-50.

Kratochwill, T. R., Hitchcock, J. H., Horner, R. H., Levin, J. R., Odom, S. L., Rindskopf, D. M., \& Shadish, W. R. (2013). Single-case intervention research design standards. Remedial and Special Education, 34 (1), pp. 26-38.

Kohlenberg, R. J., \& Tsai, M. (2001). Psicoterapia analítica funcional: criando relações terapêuticas e curativas (R. R. Kerbauy, Trad). Santo André: ESETec, Editores Associados. (Trabalho original publicado em 1991).

Kohlenberg, R. J., Kanter, J. W., Bolling, M. Y., Parker, C., \& Tsai, M. (2002). Enhancing cognitive therapy for depression with funciontal analytic psychotherapy: Treatment guidelines and empirical findings. Cognitive and Behavioral Practice, 9(3), 213-229.

Kohlenberg, R. J., Tsai, M., Parker, C. R., Rolling, M. Y., \& Kanter, J. W. (1999). Focusing on the Client-Therapist Interaction - Functional Analytic Psychotherapy: A Behavioral Approach. European Psychotherapy, 1(1), 15-25.

Landis, J. R., \& Koch, G. C. (1977). The measurement of observer agreement for categorical data. Biometrics, 33 (1), 159-74. 
Lambert, M. J., Burlingame, G. M., Umphress, V., Hansen, N. B., Vermeersch, D. A., Clouse, G. C., \& Yanchar, S. C. (1996). The reliability and validity of the Outcome Questionnaire. Clinical Psychology and Psychotherapy, 3(4), 249-258.

Levitan, Michelle N., Chagas, Marcos H. N., Crippa, José A. S., Manfro, Gisele G., Hetem, Luiz A. B., Andrada, Nathalia C., Salum, Giovanni A., Isolan, Luciano, Ferrari, Maria C. F., \& Nardi, Antonio E.. (2011). Diretrizes da Associação Médica Brasileira para o tratamento do transtorno de ansiedade social. Revista Brasileira de Psiquiatria, 33(3), 292-302.https://dx.doi.org/10.1590/S1516-44462011000300014

Liebowitz, M.R.; Gorman, J.M, Fyer, A.J. \& Klein, D.F. (1985). Social Fobia: A Review of a Neglected Anxiety Disorder. Archives og General Psychiatry, 42: 729-736.

Liebowitz, M. R. (1999). Update the diagnosis and treatment of social anxiety disorder. Journal of Clinical Psychiatric. 60(suppl 18), p. 22-26.

Lima, G. O. (2017). Psicoterapia Analítica Funcional como tratamento de Transtorno de Estresse Pós-traumático: delineamento experimental de caso único. Dissertação de Mestrado, Universidade de São Paulo, São Paulo, SP, Brasil.

Linares, I.; Perez, W. \& Nico, Y. (2013). Teoria e Aplicação: Uma breve descrição da ansiedade: Do comportamento respondent ao responder relacional. Boletim Paradifma, $v$. 8 .

Lincoln, T. M., Rief, W., Hahlweg, K., Frank, M., Schroeber, B. \& Fiegenbaum, W. (2003). Effectiveness of an empirically supported treatment for social phobia in the field. Behaviour Research and Therapy, 41(11), p. 1251-1269.

López Bermúdez, M. A., García, R. F., Calvillo, M. (2010). An application of functional analytic psychotherapy in a case of anxiety panic disorder without agoraphobia. International Journal of Behavioral Consultation and Therapy, 6 (4), 356-372. http://dx.doi.org/10.1037/h0100916

Lotufo-Neto, F. (2000). Escalas para avaliação de fobias. In: Gorenstein C., Andrade, L. H. S. G., Zuardi, A. W. Escalas de avaliação clínica em psiquiatria e psicofarmacologia. São Paulo: Lemos Editorial, p. 157-164.

Lucock,_M. P. \& Salkovskis, P. M. (1988). Cognitive factors in social anxiety and its treatment. Behaviour Research_and Therapy, 26(4), 297-302.

Malerbi, F. K., Savoia, M. G., Bernik, M. A. (2000). Aderência ao tratamento em fóbicos sociais: um estudo qualitativo. Revista Brasileira de Terapia Comportamental e Cognitiva, Vol 2, n², 147-155.

Manduchi, K., Schoendorff, B. (2012). First steps in FAP: Experiences of beginning Functional Analytic Psychotherapy therapist with an obsessive-compulsive personality disorder client. International Journal of Behavioral Consultation and Therapy, Vol 7 (23), 72-77. http://dx.doi.org/10.1037/h0100940 
Mangabeira, V., Kanter, J., \& Del Prette, G. (2012). Functional analytic psychotherapy (FAP): A review of publications from 1990 to 2010. International Journal of Behavioral Consultation and Therapy, 7, 78-89.

Mattick, R. P., Peters, L. \& Clarke, J. C. (1989). Exposure and cognitive restructuring for social phobia: A controlled study. Behavior Therapy, 20(1), 3-23.

Mattick, R. P. \& Peters, L. (1988). Treatment of severe social phobia: Effects of guided exposure with and without cognitive restructuring. Journal of Consulting and Clinical Psychology, 56(2), 251-260.

McManus, F., Clark, D. M. \& Hackmann, A. (2000). Specificity of cognitive bases in social phobia and their role in recorery. Behavioural and Cognitive Psychotherapy, 28(3), 201209.

Mendes, N. A., \& Vandenberghe, L. (2009). O relacionamento terapeuta-cliente no tratamento do transtorno obsessivo compulsivo. Estudos de Psicologia (Campinas), 26(4), 545-552. https://dx.doi.org/10.1590/S0103-166X2009000400014

Mersch,_P. P. A. (1995). The treatment of social phobia: The differential effectiviness of exposure in vivo and na integration of exposure in vivo, rational emotive therapy and social skills training. Behaviour Research and Therapy, 33(2), 259-269.

Mestre, M., \& Corassa, N. (2000). Da ansiedade à fobia. Revista Psicologia Argumento. ISSN 0103-7013. Ano XVIII, No XXVI,p. 105-126. Disponível em: <http:// www.medos.com.br/estudos-cientificos/> . Acesso em: 21 nov. 2017.

Meyer, S. B. (2009). Análise de solicitação de informação e recomendação em branco de dados de terapias comportamentais. Tese de livre docência, Universidade de São Paulo.

Moreira, F. R. (2017). Os efeitos da Psicoterapia Analítica Funcional (FAP) no tratamento de crianças vítimas de abuso sexual. Qualificação de Mestrado, Universidade de São Paulo, SP, Brasil.

Muller, J. de L., Trentini, C. M., Zanini, A. M. \& Lopes, F. M. (2015). Transtorno de Ansiedade Social: um estudo de caso. Contextos Clínicos, 8(1), 67-78.

Munaretti, C.L., \& Terra, M. B. (2007). Transtorno de ansiedade: um estudo de prevalência e comorbidade com tabagismo em um ambulatório de psiquiatria. J. Bras Psiquiatr, 56 (Supl. 2), p. 108-15.

Nardi, A. E., Quevedo, J., Silva, A. G. (2014) Transtorno de Ansiedade Social - Teoria e Clínica. Porto Alegre: Artmed.

Nascimento, B. R. C. (2013). Fobia Social: a Incidência em estudantes universitários. Recuperado em 09 de junho de 2016, de https://psicologado.com/psicopatologia/transtornos-psiquicos/fobia-social-a-incidencia$\underline{\text { em-estudantes-universitarios }}$ 
Newman, M. G., Hofmann, S. G., Trabert, W., Roth, W. \& Taylor, S. (1994). Does behavioral treatment of social phobia lead to cognitive changes? Behaviour Research and Therapy, 25(5), 503-517.

Oshiro, C. K. B. (2011). Delineamento experimental de caso único: a Psicoterapia Analítica Funcional com dois clientes difíceis. Tese de Doutorado, Instituto de Psicologia, Universidade de São Paulo, São Paulo.

Oshiro, C. K. B, Kanter, J., Meyer, S. B. (2012). A single-case experimental demonstration of Functional Analytic Psychotherapy with two clientes with severe interpersonal problems. International Journal of Behavioral Consultation and Therapy, Vol 7 (2-3), 111-116. http://dx.doi.org/10.1037/h0100945

Oshiro, C. K. B., \& Assaz, D. A. (2017). Superando barreiras para exposição por meio da integração de princípios da ACT. Revista Brasileira de Terapia Comportamental e Cognitiva, v. XIX, No 3, p. 124-144.

Osório, F. L., Crippa, J. A. S.; \& Loureiro, S. R. (2003). Validação transcultural para o português da Brief Social Phobia Scale e desenvolvimento de um roteiro de perguntasguia. Revista Brasileira de Psiquiatria, v. 28, No 3.

Öst, L. G., Jerremalm, A. \& Johansson, J. (1981). Individual responses patterns and the effect of different behavioral methods in the treatment of social phobia. Behaviour Research and Therapy, 19(1), p. 1-16

Otto, M. W. (1999). Cognitive-behavioral therapy for social anxiety disorder: Model, methods and outcome. Journal of Clinical Psychiatry, 60(suppl 9), 14-19.

Pezzato, F. A., Brandão, A. S., \& Oshiro, C. K. B. (2012). Intervenção baseada na psicoterapia Analítica funcional em um caso de transtorno de pânico com agorafobia. Revista Brasileira de Terapia Comportamental e Cognitiva,15(1), 74-84.

Queiroz, P. P., \& Guilhardi, H. J. (2001). Identificação e análise de contingências geradoras de ansiedade: Caso clínico. In H. J. Guilhardi, M. B. B. P. Madi, P. P. Queiroz \& M. C. Scoz (Eds.), Sobre comportamento e cognição: Vol. 7 (pp. 257-268). Santo André, SP: ESETec.

Sampaio, A. A. S., Azevedo, F. H. B., Cardoso, L. R. D., Lima, C., Pereira, M. B. R, \& Andery, M. A. P. A. (2008). Uma introdução aos Delineamentos Experimentais de Sujeito Único. Interação em Psicologia, 12(1), 151-164.

Sidman, M. (1989/2009). Coerção e suas implicações. Campinhas: Livro Pleno.

Shaw, P. (1979). A comparison of three behaviour therapies in the treatment of social phobia. British Journal of Psychiatry, 134(6), 620-623.

Silvares, E. F. M., \& Meyer, S. B. (2000). Análise funcional da fobia social em uma concepção behaviorista radical. Revista de Psiquiatria Clínica, v. 27 (6), p. 329-334. 
Skinner, B. F. (1953). Ciência e Comportamento Humano, $11^{\mathrm{a}}$ ed. São Paulo: Martins Fontes, 2003. (obra original publicada em 1953).

Skiner, B. F. (1957). The experimental analysis of behavior. American Scientist, vol. 45 (4), p. 343-371.

Taylor, S., Woody, S., Koch, W. J., McLean, P., Patterson, R. J. \& Anderson, K. W. (1997). Cognitive restructuring in the treatment of social phobia: Efficacy and mode of action. Behaviour Modification, 21(4), 487-511.

Tsai, M., Kohlenberg, R. J., Kanter, J. W., Kohlenberg, B., Follete, W. C., \& Callaghan, G. M. (2011). Um guia para a Psicoterapia Analítica Funcional (FAP): consciência, coragem, amor e behaviorismo (F. Conte, \& M. Z. Brandão, trads.). Santo André, SP: ESETEc (Obra publicada originalmente em 2009).

Turner, S. M., Beidel, D. \& Cooley, M. R. (1994). A multicomponent of behavioral treatment for social phobia: Social effectiveness therapy. Behaviour Research and Therapy, 32(3), 381-390.

Valença, A. M. (2014). Psicopatologia e diagnóstico. Em A. E. Nardi, J. Quevedo \& A. G. da Silva (Orgs.), Transtorno de Ansiedade Social: Teoria e clínica, p. 49-55. Porto Alegre: Artmed.

Vandenberghe, L. (2007). Functional Analytic Psychotherapy and the treatment of Obsessive Compulsive Disorder. Counseling Psychology Quarterly, Volume 20 Issue 1, March, 105-114.

Vartanian, J. F. (2017). Efeitos da evocação sobre os comportamentos clinicamente relevantes na psicoterapia analítica funcional. Dissertação de Mestrado, Universidade de São Paulo, São Paulo, Brasil.

Villas-Bôas, A. (2015). Efeitos de análises de contingências sobre comportamentos clinicamente relevantes e sobre mudanças extrassessão. (Tese de Doutorado, Instituto de Psicologia, Universidade de São Paulo, São Paulo). Recuperado de http://www.teses.usp.br/teses/disponiveis/47/47133/tde-24092015-154310/pt-br.php.

Vorkapic, C. F., \& Rangé, B. (2011). Os benefícios do yoga nos transtornos de ansiedade. Revista Brasileira de Terapias Cognitivas, v. 7, n. 1, p. 50-54. Disponível em: <http://pepsic.bvsalud.org/pdf/rbtc/v7n1/v7n1a09.pdf>. Acesso em: 23 jan. 2018.

Wampold, B. E. How important are common factors in psychotherapy?: An update. World $\begin{array}{llllll}\text { Psychiatry. } & \text { v. } & 14 & \text { p.270-277, } 2015 . & \text { Disponível em: }\end{array}$ <https://www.ncbi.nlm.nih.gov/pmc/articles/PMC4592639>

Wolpe, J. (1973, $2^{\mathrm{a}}$ ed.). The practice of behavior therapy. London: Pergamon.

Zamignani, D. R. (2001). Uma tentativa de caracterização da prática clínica do analista do comportamento no atendimento de clientes com e sem o diagnóstico de transtorno obsessivo-compulsivo. Dissertação de mestrado, Pontifícia Universidade Católica de São Paulo, São Paulo, Brasil. 
Zamignani, D.R. \& Banaco, R.A. (2005). Um panorama Analítico- Comportamental sobre os Transtornos de ansiedade. Revista Brasileira de Terapia Comportamental e Cognitiva, vol VII, no.1, 077-092.

Zamignani, D. R., \& Vermes, J. S. (2003). Propostas analítico-comportamentais para o manejo de transtornos de ansiedade: Análise de casos clínicos. In H. M. Sadi \& N. M. S. Castro. (Eds.), Ciência do comportamento. Conhecer e avançar: Vol. 3 (pp. 117-135). Santo André, SP: ESETec.

Zettle, R. D. (2003). Acceptance and commitment therapy (ACT) vc systematic desensitization in treatment of mathematics anxiety. The Psychological Record, 53, 197215. 


\section{ANEXO 1}

\section{OQ-45.2}

(Lambert \& Burlingame, 1996)

Versão autorizada para investigação

Instrucões: Para nos ajudar a compreender como você tem se sentido, considere a última semana, incluindo o dia de hoje.

Leia atentamente cada pergunta e assinale com um " $X$ " a categoria que melhor descreve o seu estado atual. Lembre-se: Neste questionário, "trabalho" é definido como emprego, escola, trabalho doméstico, trabalho voluntário, etc. Por favor responda a todas as questões.

\begin{tabular}{|l|c|c|c|c|c|}
\hline & Nunca & Raramente & $\begin{array}{c}\text { Ass } \\
\text { Vezes }\end{array}$ & Freqüentemente & Sempre \\
\hline 1. Eu me dou bem com os outros. & $\square$ & $\square$ & $\square$ & $\square$ & $\square$ \\
\hline 2. Eu me canso depressa. & $\square$ & $\square$ & $\square$ & $\square$ & $\square$ \\
\hline 3. Eu não tenho interesse pelas coisas. & $\square$ & $\square$ & $\square$ & $\square$ & $\square$ \\
\hline 4. Eu me sinto estressado no trabalho. & $\square$ & $\square$ & $\square$ & $\square$ & $\square$ \\
\hline 5. Eu me culpo pelas coisas. & $\square$ & $\square$ & $\square$ & $\square$ & $\square$ \\
\hline 6. Eu me sinto irritado. & $\square$ & $\square$ & $\square$ & $\square$ & $\square$ \\
\hline $\begin{array}{l}\text { 7. Eu me sinto infeliz no meu } \\
\text { casamento ou relacionamento } \\
\text { importante. }\end{array}$ & $\square$ & $\square$ & $\square$ & $\square$ & $\square$ \\
\hline $\begin{array}{l}\text { 8. Eu tenho pensamentos sobre acabar } \\
\text { com minha vida. }\end{array}$ & $\square$ & $\square$ & $\square$ & $\square$ & $\square$ \\
\hline 9. Eu me sinto fraco. & $\square$ & $\square$ & $\square$ & $\square$ & $\square$ \\
\hline 10. Eu me sinto assustado/ com medo. & $\square$ & $\square$ & $\square$ & $\square$ & $\square$ \\
\hline $\begin{array}{l}\text { 11. Depois de beber bebidas } \\
\text { alcoólicas, preciso beber bebidas } \\
\text { alcoólicas na manhã seguinte para } \\
\text { começar o dia. } \\
\text { (se não bebe marque nunca) }\end{array}$ & $\square$ & $\square$ & $\square$ & $\square$ & $\square$ \\
\hline 12. Eu acho meu trabalho satisfatório. & $\square$ & $\square$ & $\square$ & & $\square$ \\
\hline 13. Eu sou uma pessoa feliz. & $\square$ & $\square$ & $\square$ & $\square$ & $\square$ \\
\hline 14. Eu trabalho muito. & $\square$ & $\square$ & $\square$ & $\square$ & $\square$ \\
\hline 15. Eu me sinto sem valor. & $\square$ & $\square$ & $\square$ & $\square$ & $\square$ \\
\hline $\begin{array}{l}\text { 16. Eu estou preocupado com } \\
\text { problemas familiares. }\end{array}$ & $\square$ & $\square$ & $\square$ & $\square$ & $\square$ \\
\hline $\begin{array}{l}\text { 17. Eu tenho uma vida sexual } \\
\text { insatisfatória. }\end{array}$ & $\square$ & $\square$ & $\square$ & $\square$ & $\square$ \\
\hline 18. Eu me sinto sozinho. & $\square$ & $\square$ & $\square$ & $\square$ & $\square$ \\
\hline 19. Eu discuto com freqüência. & $\square$ & $\square$ & $\square$ & $\square$ & $\square$ \\
\hline 20. Eu me sinto amado e querido. & $\square$ & $\square$ & $\square$ & $\square$ \\
\hline 21. Eu aproveito o meu tempo livre. & $\square$ & $\square$ & $\square$ & $\square$ & $\square$ \\
\hline $\begin{array}{l}\text { 22. Eu tenho dificuldade em me } \\
\text { concentrar. }\end{array}$ & $\square$ & $\square$ & $\square$ & $\square$ \\
\hline
\end{tabular}

Nome:

Idade: ID:

Data: 


\begin{tabular}{|c|c|c|c|c|c|}
\hline & Nunca & Raramente & $\begin{array}{c}\text { Às } \\
\text { Vezes }\end{array}$ & Freqüentemente & Sempre \\
\hline $\begin{array}{l}\text { 23. Eu me sinto sem esperanças sobre } \\
\text { o futuro. }\end{array}$ & $\square$ & $\square$ & $\square$ & $\square$ & $\square$ \\
\hline 24. Eu gosto de mim. & $\square$ & $\square$ & $\square$ & $\square$ & $\square$ \\
\hline $\begin{array}{l}\text { 25. Surgem pensamentos } \\
\text { perturbadores na minha cabeça dos } \\
\text { quais não consigo me livrar. }\end{array}$ & $\square$ & $\square$ & $\square$ & $\square$ & $\square$ \\
\hline $\begin{array}{l}\text { 26. Fico incomodado com pessoas que } \\
\text { criticam o meu consumo de álcool (ou } \\
\text { uso de drogas). } \\
\text { (se não se aplicar marque nunca) }\end{array}$ & $\square$ & $\square$ & $\square$ & $\square$ & $\square$ \\
\hline 27. Eu tenho problemas de estômago. & $\square$ & $\square$ & $\square$ & $\square$ & $\square$ \\
\hline $\begin{array}{l}\text { 28. Não tenho trabalhado tão bem } \\
\text { quanto antes. }\end{array}$ & $\square$ & $\square$ & $\square$ & $\square$ & $\square$ \\
\hline $\begin{array}{l}\text { 29. O meu coração bate de maneira } \\
\text { acelerada. }\end{array}$ & $\square$ & $\square$ & $\square$ & $\square$ & $\square$ \\
\hline $\begin{array}{l}\text { 30. Eu tenho problemas em relacionar- } \\
\text { me com amigos e colegas próximos. }\end{array}$ & $\square$ & $\square$ & $\square$ & $\square$ & $\square$ \\
\hline $\begin{array}{l}\text { 31. Eu estou satisfeito com a minha } \\
\text { vida. }\end{array}$ & $\square$ & $\square$ & $\square$ & $\square$ & $\square$ \\
\hline $\begin{array}{l}\text { 32. Eu tenho problemas no trabalho } \\
\text { por consumir álcool ou usar drogas. } \\
\text { (Se não se aplicar marque nunca) }\end{array}$ & $\square$ & $\square$ & $\square$ & $\square$ & $\square$ \\
\hline $\begin{array}{l}\text { 33. Eu sinto que alguma coisa de ruim } \\
\text { vai acontecer. }\end{array}$ & $\square$ & $\square$ & $\square$ & $\square$ & $\square$ \\
\hline 34. Eu tenho os músculos doloridos. & $\square$ & $\square$ & $\square$ & $\square$ & $\square$ \\
\hline $\begin{array}{l}\text { 35. Eu tenho medo de espaços abertos, } \\
\text { de dirigir ou de estar em ônibus, } \\
\text { metrôs, etc. }\end{array}$ & $\square$ & $\square$ & $\square$ & $\square$ & $\square$ \\
\hline 36. Eu me sinto nervoso. & $\square$ & $\square$ & $\square$ & $\square$ & $\square$ \\
\hline $\begin{array}{l}\text { 37. Eu sinto que meus relacionamentos } \\
\text { amorosos são satisfatórios e } \\
\text { completos. }\end{array}$ & $\square$ & $\square$ & $\square$ & $\square$ & $\square$ \\
\hline $\begin{array}{l}\text { 38. Eu sinto que não estou fazendo as } \\
\text { coisas direito no trabalho. }\end{array}$ & $\square$ & $\square$ & $\square$ & $\square$ & $\square$ \\
\hline $\begin{array}{l}\text { 39. Eu tenho muitos desentendimentos } \\
\text { no trabalho. }\end{array}$ & $\square$ & $\square$ & $\square$ & $\square$ & $\square$ \\
\hline $\begin{array}{l}\text { 40. Eu sinto que algo não está bem } \\
\text { com a minha cabeça. }\end{array}$ & $\square$ & $\square$ & $\square$ & $\square$ & $\square$ \\
\hline $\begin{array}{l}\text { 41. Eu tenho problemas em adormecer } \\
\text { ou continuar dormindo. }\end{array}$ & $\square$ & $\square$ & $\square$ & $\square$ & $\square$ \\
\hline 42. Eu me sinto triste. & $\square$ & $\square$ & $\square$ & $\square$ & $\square$ \\
\hline $\begin{array}{l}\text { 43. Eu estou satisfeito com meus } \\
\text { relacionamentos com os outros. }\end{array}$ & $\square$ & $\square$ & $\square$ & $\square$ & $\square$ \\
\hline $\begin{array}{l}\text { 44. Eu sinto raiva suficiente no } \\
\text { trabalho para vir a fazer algo de que } \\
\text { posso me arrepender. }\end{array}$ & $\square$ & $\square$ & $\square$ & $\square$ & $\square$ \\
\hline 45. Eu tenho dores de cabeça. & $\square$ & $\square$ & $\square$ & $\square$ & $\square$ \\
\hline & & & & & \\
\hline
\end{tabular}




\begin{abstract}
ANEXO 2
INVENTÁRIO DE DEPRESSÃO DE BECK - BDI

Nome:

Idade:

Data:

Este questionário consiste em 21 grupos de afirmações. Depois de ler cuidadosamente cada grupo, faça um círculo em torno do número $(0,1,2$ ou 3$)$ próximo à afirmação, em cada grupo, que descreve melhor a maneira que você tem se sentido na última semana, incluindo hoje. Se várias afirmações num grupo parecerem se aplicar igualmente bem, faça um círculo em cada uma. Tome cuidado de ler todas as afirmações, em cada grupo, antes de fazer sua escolha.
\end{abstract}

\begin{tabular}{|c|c|c|c|}
\hline 1 & $\begin{array}{l}0 \text { Não me sinto triste } \\
1 \text { Eu me sinto triste } \\
2 \text { Estou sempre triste e não consigo sair } \\
\text { disto } \\
3 \text { Estou tão triste ou infeliz que não } \\
\text { consigo suportar }\end{array}$ & 7 & 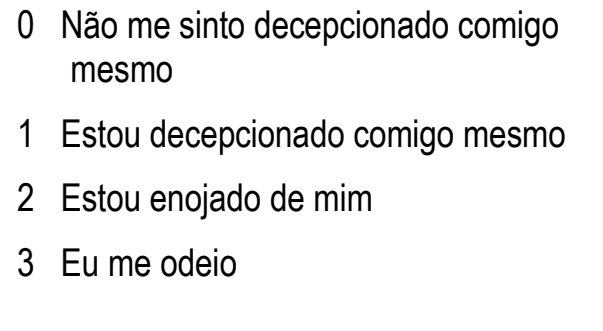 \\
\hline 2 & $\begin{array}{l}0 \text { Não estou especialmente desanimado } \\
\text { quanto ao futuro } \\
1 \text { Eu me sinto desanimado quanto ao } \\
\text { futuro } \\
2 \text { Acho que nada tenho a esperar } \\
3 \text { Acho o futuro sem esperanças e tenho } \\
\text { a impressão de que as coisas não podem } \\
\text { melhorar }\end{array}$ & 8 & $\begin{array}{l}0 \text { Não me sinto de qualquer modo pior } \\
\text { que os outros } \\
1 \text { Sou crítico em relação a mim por } \\
\text { minhas fraquezas ou erros } \\
2 \text { Eu me culpo sempre por minhas } \\
\text { falhas } \\
3 \text { Eu me culpo por tudo de mal que } \\
\text { acontece }\end{array}$ \\
\hline 3 & $\begin{array}{l}0 \text { Não me sinto um fracasso } \\
1 \text { Acho que fracassei mais do que uma } \\
\text { pessoa comum } \\
2 \text { Quando olho pra trás, na minha vida, } \\
\text { tudo o que posso ver é um monte de } \\
\text { fracassos } \\
3 \text { Acho que, como pessoa, sou um } \\
\text { completo fracasso }\end{array}$ & 9 & $\begin{array}{l}0 \text { Não tenho quaisquer idéias de me } \\
\text { matar } \\
1 \text { Tenho idéias de me matar, mas não } \\
\text { as executaria } \\
2 \text { Gostaria de me matar } \\
3 \text { Eu me mataria se tivesse oportunidade }\end{array}$ \\
\hline 4 & $\begin{array}{l}0 \text { Tenho tanto prazer em tudo como } \\
\text { antes } \\
1 \text { Não sinto mais prazer nas coisas } \\
\text { como antes } \\
2 \text { Não encontro um prazer real em mais } \\
\text { nada } \\
3 \text { Estou insatisfeito ou aborrecido com } \\
\text { tudo }\end{array}$ & 10 & $\begin{array}{l}0 \text { Não choro mais que o habitual } \\
1 \text { Choro mais agora do que costumava } \\
2 \text { Agora, choro o tempo todo } \\
3 \text { Costumava ser capaz de chorar, mas } \\
\text { agora não consigo, mesmo que o queria }\end{array}$ \\
\hline
\end{tabular}




\begin{tabular}{|c|c|c|c|}
\hline 5 & $\begin{array}{l}0 \text { Não me sinto especialmente culpado } \\
1 \text { Eu me sinto culpado grande parte do } \\
\text { tempo } \\
2 \text { Eu me sinto culpado na maior parte } \\
\text { do tempo } \\
3 \text { Eu me sinto sempre culpado }\end{array}$ & 11 & $\begin{array}{l}0 \text { Não sou mais irritado agora do que já } \\
\text { fui } \\
1 \text { Fico aborrecido ou irritado mais } \\
\text { facilmente do que costumava } \\
2 \text { Agora, eu me sinto irritado o tempo } \\
\text { todo } \\
3 \text { Não me irrito mais com coisas que } \\
\text { costumavam me irritar }\end{array}$ \\
\hline 6 & $\begin{array}{l}0 \text { Não acho que esteja sendo punido } \\
1 \text { Acho que posso ser punido } \\
2 \text { Creio que vou ser punido } \\
3 \text { Acho que estou sendo punido }\end{array}$ & 12 & $\begin{array}{l}0 \text { Não perdi o interesse pelas outras } \\
\text { pessoas } \\
1 \text { Estou menos interessado pelas outras } \\
\text { pessoas do que costumava estar } \\
2 \text { Perdi a maior parte do meu interesse } \\
\text { pelas outras pessoas } \\
3 \text { Perdi todo o interesse pelas outras } \\
\text { pessoas }\end{array}$ \\
\hline 13 & $\begin{array}{l}0 \text { Tomo decisões tão bem quanto antes } \\
1 \text { Adio as tomadas de decisões mais do } \\
\text { que costumava } \\
2 \text { Tenho mais dificuldades de tomar } \\
\text { decisões do que antes } \\
3 \text { Absolutamente não consigo mais } \\
\text { tomar decisões }\end{array}$ & 18 & $\begin{array}{l}0 \text { O meu apetite não está pior do que o } \\
\text { habitual } \\
1 \text { Meu apetite não é tão bom como } \\
\text { costumava ser } \\
2 \text { Meu apetite é muito pior agora } \\
3 \text { Absolutamente não tenho mais apetite }\end{array}$ \\
\hline 14 & $\begin{array}{l}0 \text { Não acho que de qualquer modo } \\
\text { pareço pior do que antes } \\
1 \text { Estou preocupado em estar } \\
\text { parecendo velho ou sem atrativo } \\
2 \text { Acho que há mudanças permanentes } \\
\text { na minha aparência, que me fazem } \\
\text { parecer sem atrativo } \\
3 \text { Acredito que pareço feio }\end{array}$ & 19 & $\begin{array}{l}0 \text { Não tenho perdido muito peso se é } \\
\text { que perdi algum recentemente } \\
1 \text { Perdi mais do que } 2 \text { quilos e meio } \\
2 \text { Perdi mais do que } 5 \text { quilos } \\
3 \text { Perdi mais do que } 7 \text { quilos } \\
\text { Estou tentando perder peso de propósito, } \\
\text { comendo menos: Sim _ Não }\end{array}$ \\
\hline 15 & $\begin{array}{l}0 \text { Posso trabalhar tão bem quanto antes } \\
1 \text { É preciso algum esforço extra para } \\
\text { fazer alguma coisa } \\
2 \text { Tenho que me esforçar muito para } \\
\text { fazer alguma coisa } \\
3 \text { Não consigo mais fazer qualquer } \\
\text { trabalho }\end{array}$ & 20 & $\begin{array}{l}0 \text { Não estou mais preocupado com a } \\
\text { minha saúde do que o habitual } \\
1 \text { Estou preocupado com problemas } \\
\text { físicos, tais como dores, indisposição } \\
\text { do estômago ou constipação } \\
2 \text { Estou muito preocupado com } \\
\text { problemas físicos e é difícil pensar } \\
\text { em outra coisa } \\
3 \text { Estou tão preocupado com meus } \\
\text { problemas físicos que não consigo pensar } \\
\text { em qualquer outra coisa }\end{array}$ \\
\hline
\end{tabular}




\begin{tabular}{|c|c|c|c|}
\hline 16 & $\begin{array}{l}0 \text { Consigo dormir tão bem como o } \\
\text { habitual } \\
1 \text { Não durmo tão bem como costumava } \\
2 \text { Acordo } 1 \text { a } 2 \text { horas mais cedo do que } \\
\text { habitualmente e acho difícil voltar a } \\
\text { dormir } \\
3 \text { Acordo várias horas mais cedo do que } \\
\text { costumava e não consigo voltar a dormir }\end{array}$ & 21 & $\begin{array}{l}0 \text { Não notei qualquer mudança recente } \\
\text { no meu interesse por sexo } \\
1 \text { Estou menos interessado por sexo do } \\
\text { que costumava } \\
2 \text { Estou muito menos interessado por } \\
\text { sexo agora } \\
3 \text { Perdi completamente o interesse por } \\
\text { sexo }\end{array}$ \\
\hline 17 & $\begin{array}{l}0 \text { Não fico mais cansado do que o } \\
\text { habitual } \\
1 \text { Fico cansado mais facilmente do que } \\
\text { costumava } \\
2 \text { Fico cansado em fazer qualquer coisa } \\
3 \text { Estou cansado demais para fazer } \\
\text { qualquer coisa }\end{array}$ & & \\
\hline
\end{tabular}


ANEXO 3

Escal a de Fobia Social - Li ebowitz

Nome:

Data:

Idade

Aplicador:

\begin{tabular}{|c|c|c|}
\hline & 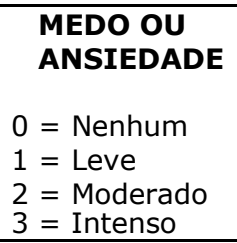 & $\begin{array}{l}\text { EVITAÇÃO } \\
0=\text { Nunca } \\
1=\text { Ocasionalmente } \\
2=\text { Freqüentemente } \\
3=\text { Geralmente }\end{array}$ \\
\hline 1. Telefonar em público $(P)$. & & \\
\hline 2. Participar de pequenos grupos (P). & & \\
\hline 3. Comer em locais públicos $(\mathrm{P})$. & & \\
\hline 4. Beber com outros em locais públicos $(P)$. & & \\
\hline 5. Falar com pessoas em posição de autoridade (S). & & \\
\hline 6. Agir, realizar ou falar em frente a uma audiência $(P)$. & & \\
\hline 7. Ir a uma festa (S). & & \\
\hline 8. Trabalhar sendo observado $(P)$. & & \\
\hline 9. Escrever sendo observado $(P)$. & & \\
\hline $\begin{array}{l}\text { 10. Chamar alguém que você não conhece muito bem } \\
\text { (S). }\end{array}$ & & \\
\hline $\begin{array}{l}\text { 11. Falar com pessoas que você não conhece muito bem } \\
\text { (S). }\end{array}$ & & \\
\hline 12. Encontrar com estranhos (S). & & \\
\hline 13. Urinar em banheiro público $(P)$. & & \\
\hline $\begin{array}{l}\text { 14. Entrar em uma sala onde outros já estão sentados } \\
\text { (P). }\end{array}$ & & \\
\hline 15. Ser o centro das atenções $(S)$ & & \\
\hline 16. Falar em uma reunião $(P)$. & & \\
\hline 17. Fazer uma prova $(P)$. & & \\
\hline $\begin{array}{l}\text { 18. Expressar uma discordância ou desaprovação para } \\
\text { pessoas que } \\
\text { você não conheça bem }(\mathrm{S}) \text {. }\end{array}$ & & \\
\hline $\begin{array}{l}\text { 19. Olhar nos olhos de pessoa que você não conheça } \\
\text { bem (S). }\end{array}$ & & \\
\hline 20. Relatar algo para um grupo $(P)$ & & \\
\hline 21. Tentar paquerar alguém (P). & & \\
\hline 22. Devolver mercadorias para uma loja (S). & & \\
\hline 23. Dar uma festa (S) & & \\
\hline 24. Resistir as pressões de um vendedor (S). & & \\
\hline
\end{tabular}


ESCORE TOTAL.

ANSIEDADE DE PERFORMANCE (P).

ANSIEDADE SOCIAL (S). 


\section{ANEXO 4 \\ INVENTÁRIO DE FOBIA SOCIAL (SPIN)}

Por favor, indique quanto os seguintes problemas incomodaram você durante a última semana. Marque somente um item para cada problema e verifique se respondeu a todos os itens.

\begin{tabular}{|c|c|c|c|c|c|}
\hline & $\underline{\text { Nada }}$ & $\underset{\text { pouco }}{\mathrm{Um}}$ & $\begin{array}{l}\text { Modera } \\
\text { damente }\end{array}$ & Bastante & $\begin{array}{l}\text { Extrema } \\
\text { mente }\end{array}$ \\
\hline 1 - Tenho medo de autoridade & $\mathbf{0}$ & 1 & 2 & 3 & 4 \\
\hline 2- Incomodo-me por ficar vermelho na frente das pessoas & $\mathbf{0}$ & 1 & 2 & 3 & 4 \\
\hline 3- Festas e eventos sociais me assustam & $\mathbf{0}$ & 1 & 2 & 3 & 4 \\
\hline 4- Evito falar com pessoas que não conheço & $\mathbf{0}$ & 1 & 2 & 3 & 4 \\
\hline 5- Fico muito assustado em ser criticado & $\mathbf{0}$ & 1 & 2 & 3 & 4 \\
\hline $\begin{array}{l}\text { 6- Evito fazer coisas ou falar com certas pessoas por medo de ficar } \\
\text { envergonhado }\end{array}$ & $\mathbf{0}$ & 1 & 2 & 3 & 4 \\
\hline 7- Transpirar na frente das pessoas me incomoda & $\mathbf{0}$ & 1 & 2 & 3 & 4 \\
\hline 8- Evito ir a festas & $\mathbf{0}$ & 1 & 2 & 3 & 4 \\
\hline 9- Evito atividades nas quais sou o centro das atenções & $\mathbf{0}$ & 1 & 2 & 3 & 4 \\
\hline 10- Conversar com estranhos me assusta & $\mathbf{0}$ & 1 & 2 & 3 & 4 \\
\hline 11- Evito falar para uma plateia ou dar discursos & $\mathbf{0}$ & 1 & 2 & 3 & 4 \\
\hline 12- Faço qualquer coisa para não ser criticado & $\mathbf{0}$ & 1 & 2 & 3 & 4 \\
\hline $\begin{array}{l}\text { 13- Sentir palpitações cardíacas me incomoda quando estou no meio de } \\
\text { outras pessoas }\end{array}$ & $\mathbf{0}$ & 1 & 2 & 3 & 4 \\
\hline 14 - Tenho receio de fazer coisas quando posso estar sendo observado & $\mathbf{0}$ & 1 & 2 & 3 & 4 \\
\hline 15- Ficar envergonhado ou parecer bobo são meus maiores temores & $\mathbf{0}$ & 1 & 2 & 3 & 4 \\
\hline 16- Evito falar com qualquer autoridade & $\mathbf{0}$ & 1 & 2 & 3 & 4 \\
\hline 17- Tremer ou estremecer na frente das outras pessoas me angustia & O & 1 & 2 & 3 & 4 \\
\hline
\end{tabular}




\section{ANEXO 5 \\ TERMO DE CONSENTIMENTO LIVRE E ESCLARECIDO}

Antes de concordar em participar desta pesquisa, é muito importante que você compreenda as informações e instruções contidas neste documento. E, antes que você decida participar, a pesquisadora deve esclarecer todas as suas dúvidas. Você tem o direito de desistir de participar da pesquisa a qualquer momento, sem nenhum ônus.

Convidamos você a participar, de formar totalmente voluntária, da pesquisa científica, cujo objetivo é analisar a eficácia da Psicoterapia Analítica Funcional (FAP) em casos de Transtorno de Ansiedade Social. Nesta pesquisa, você é convidado a comparecer ao Instituto de Psicologia da Universidade de São Paulo e participar de sessões semanais de psicoterapia, com um psicólogo terapeuta-pesquisador. A duração da pesquisa está prevista para semanas.

A sua participação neste estudo é voluntária, não havendo recompensa financeira pela participação. Como o estudo inclui, em seus procedimentos, uma intervenção psicológica, está prevista acompanhamento terapêutico e/ou assistência após o término dessa pesquisa, se for de vontade do participante.

O objetivo da pesquisa é o tratamento do Transtorno de Ansiedade Social através da Psicoterapia Analítica Funcional (FAP), uma terapia comportamental. Sendo assim, os eventuais benefícios são a redução dos sintomas causados pelo transtorno. O pesquisador (a) assume o compromisso de que a participação na pesquisa oferecerá riscos mínimos, como desconfortos psicológicos, e ocorrendo, serão tomadas as medidas necessárias para o caso, como acolhimento do participante em serviço terapêutico pelo psicólogo terapeuta-pesquisador, sem custos para o participante.

As informações fornecidas por você serão tratadas como confidenciais, de forma que você não será identificado (a) em nenhum momento, mesmo quando os resultados da pesquisa forem divulgados em qualquer forma. Como procedimento da pesquisa, será necessária a gravação por áudio das sessões, como forma de acompanhar e categorizar 
resultados, sempre mantendo o sigilo do participante. Desta forma, haverá total sigilo acerca do procedimento, visto que, os dados da pesquisa serão analisados de forma individual.

É garantido a você tomar conhecimento e obter informações, a qualquer tempo, dos procedimentos e métodos utilizados, neste estudo, bem como dos resultados parciais e finais desta pesquisa. Para tanto, a pesquisadora responsável poderá ser contatada a qualquer momento. E a pesquisa será divulgada no site da biblioteca do Instituto de Psicologia da Universidade de São Paulo, bem como também no portal da Biblioteca Digital Brasileira de Teses e Dissertações, para socialização dos resultados da pesquisa.

$\mathrm{Eu}$, portador (a) da carteira de identidade $\mathrm{RG} \mathrm{n}^{\mathrm{o}}$ declaro que obtive todas as informações necessárias e esclarecimentos quanto às dúvidas por mim apresentadas e, por concordar em participar da pesquisa "Psicoterapia Analítica Funcional como Tratamento de Transtorno de Ansiedade Social: delineamento experimental de caso único", assino o presente documento em 02 (vias) de igual teor e forma, ficando uma via em minha posse.

São Paulo, de de 20

Participante da Pesquisa

Eu, ALINE REDRESSA BONI RAYIS LOVO, pesquisadora responsável pelo estudo, zelarei pera que todos os procedimentos descritos sejam cumpridos integralmente.

Pesquisador (a) 